NBER WORKING PAPER SERIES

\title{
THE RISE OF EUROPE: ATLANTIC TRADE, INSTITUTIONAL CHANGE AND ECONOMIC GROWTH
}

\author{
Daron Acemoglu \\ Simon Johnson \\ James Robinson \\ Working Paper 9378 \\ http://www.nber.org/papers/w9378
NATIONAL BUREAU OF ECONOMIC RESEARCH
1050 Massachusetts Avenue
Cambridge, MA 02138 \\ December 2002
}

We thank Thomas Becker and Rui Pedro Esteves for outstanding research assistance and Josh Angrist, Abhijit Banerjee, Dora Costa, Jan de Vries, Stanley Engerman, Philip Hoffman, Peter Lindert, Sebastían Mazzuca, Joel Mokyr, Larry Neal, Steve Pincus, Christina Romer, David Romer, Andrei Shleifer, Alan Taylor, HansJoachim Voth, and seminar participants at Berkeley, the Canadian Institute of Advanced Research, Chicago Business School and Political Science, George Mason University, Harvard Business School, the Harvard Economic History Seminar, the London School of Economics, MIT, the National Bureau of Economic Research economic history, inequality and economic growth groups, New York University and Princeton for comments and suggestions. The views expressed herein are those of the authors and not necessarily those of the National Bureau of Economic Research.

(C) 2002 by Daron Acemoglu, Simon Johnson and James Robinson. All rights reserved. Short sections of text, not to exceed two paragraphs, may be quoted without explicit permission provided that full credit, including (C) notice, is given to the source. 
The Rise of Europe: Atlantic Trade, Institutional Change and Economic Growth Daron Acemoglu, Simon Johnson, and James Robinson

NBER Working Paper No. 9378

December 2002

JEL No. O10, F10, P10, N13

\begin{abstract}
This paper documents that the Rise of (Western) Europe between 1500 and 1850 is largely accounted for by the growth of European nations with access to the Atlantic, and especially by those nations that engaged in colonialism and long distance oceanic trade. Moreover, Atlantic ports grew much faster than other West European cities, including Mediterranean ports.

Atlantic trade and colonialism affected Europe both directly, and indirectly by inducing institutional changes. In particular, the growth of New World, African, and Asian trade after 1500 strengthened new segments of the commercial bourgeoisie, and enabled these groups to demand, obtain, and sustain changes in institutions to protect their property rights.

Furthermore, the most significant institutional changes and consequently the most substantial economic gains occurred in nations where existing institutions placed some checks on the monarchy and particularly limited its control of overseas trading activities, thus enabling new merchants in these countries to benefit from Atlantic trade. Therefore, the Rise of Europe was largely the result of capitalist development driven by the interaction of late medieval institutions and the economic opportunities offered by "Atlantic trade."
\end{abstract}

Daron Acemoglu
Department of Economics
MIT
50 Memorial Drive
Cambridge, MA 02142
and NBER
daron@mit.edu

Simon Johnson

Sloan School of Management

MIT

50 Memorial Drive, E52-562

Cambridge, MA 02142

and NBER

sjohnson@mit.edu
James Robinson

Department of Economics

and Political Science

University of California, Berkeley

Berkeley, CA 94720 
"[C]ommerce and manufactures gradually introduced order and good government, and with them, liberty and security of individuals, among the inhabitants of the country, who had before lived almost in a continual state of war with their neighbours, and of servile dependency upon their superiors. This, though it has been least observed, is by far the most important of all of their effects." (Adam Smith, The Wealth of Nations, Book III, Chapter IV).

"The discovery of America, the rounding of the Cape, opened up fresh ground for the rising bourgeoisie. The East-Indian and Chinese markets, the colonization of America, trade with the colonies, the increase in the means of exchange and commodities generally, gave to commerce, to navigation, to industry, an impulse never before known, and thereby, to the revolutionary element in the tottering feudal society, a rapid development". (Marx and Engels, The Communist Manifesto, 1992, pp. 3-4).

\section{INTRODUCTION}

The world we live in - both our material standards of living and our society — was shaped by the process of rapid economic growth that started in the 19th century and in Europe, particularly in Western Europe. An explanation for West European economic growth must therefore be part of any unified theory of long-run growth. The origins of this rapid economic growth and the associated Industrial Revolution are generally considered to lie in the economic, political and social developments of Western Europe over the preceding centuries, most often starting in the 16th century. In fact, between 1500 and 1800, Western Europe experienced a historically unprecedented period of sustained growth, perhaps the "First Great Divergence," making this area substantially richer than Asia and Eastern Europe by the beginning of the 19th century. ${ }^{1}$ There is little agreement, however, on why the process of capitalist growth took place in Western Europe and why it started in the 16th century.

This paper presents an important fact on the origins of the First Great Divergence: almost all the differential growth of Western Europe during the 16th, 17th, 18th and early 19th centuries is accounted for by the differential growth of Atlantic traders - nations

\footnotetext{
${ }^{1}$ See, among others, North and Thomas (1973), Brenner (1977), Jones (1981), Cipolla (1981), Hall (1985), Mann (1986), Rosenberg and Birdzell (1986), Bairoch (1988), Mokyr (1990) and Maddison (2001).
} 
directly involved in trade and colonialism with the New World and Asia, i.e., Britain, France, the Netherlands, Portugal and Spain. ${ }^{2}$ This pattern, at least in part, reflects the direct effects of "Atlantic trade" between Europe and America, Africa and Asia. In addition, we present evidence suggesting that Atlantic trade also affected European growth by inducing major institutional changes among Atlantic nations, and perhaps even in the rest of Europe (see Acemoglu, Johnson and Robinson, in progress). Profits from Atlantic trade and colonialism strengthened new merchant groups, and opened the way for changes in political institutions, which constrained expropriation by the monarchy and other established groups, encouraged commerce and production for the market, and enabled the emergence of new organizational forms and technologies.

Furthermore, we document the presence of an important interaction between initial (pre-1500) institutions and access to the Atlantic: the major institutional changes and the more rapid economic growth took place in societies with relatively non-absolutist initial institutions, in particular in Britain and the Netherlands, which allowed new groups of merchants, rather than monarchies, to benefit from Atlantic trade. Countries where the monarchy was highly absolutist and monopolized overseas trade, such as Spain and Portugal, experienced only limited gains from Atlantic trade, while areas lacking easy access to the Atlantic, such as Venice and Genoa, did not experience any direct or indirect benefits of Atlantic trade.

Figures 1 and 2 illustrate the central fact of this paper using two proxies for income per capita: urbanization rates and Maddison's (2001) estimates of GDP per capita (see Section 2.1 for data sources and definitions). Figure 1 Panel A shows that urbanization in Western Europe grew significantly faster than in Eastern Europe after $1500 .^{3}$ While average urbanization (weighted by population) in 1500 was 10.7 percent in Western Europe, it was 4.0 percent in Eastern Europe and 11.5 percent in Asia (reflecting the relatively high level of urbanization in India and China). In the subsequent centuries,

\footnotetext{
${ }^{2}$ Throughout the paper, Atlantic trade means trade with the New World as well as trade with Asia via the Atlantic, and includes colonialism- and slavery-related activities as well as trade. Atlantic trade opportunities became available only during the late 15th century, thanks to the discovery of the New World and the passage to Asia around the Cape of Good Hope. These discoveries, in turn, resulted from a series of innovations in ship technology, primarily pioneered by the Portuguese, that changed the rigging and hull design of ships and developed knowledge of oceanic navigation (see, e.g., Gardiner, 2000).

${ }^{3}$ For the purposes of this paper, Western Europe is taken to be all the countries west of the Elbe, i.e., Austria, Belgium, Britain, Denmark, Finland, France, Germany, Ireland, Italy, the Netherlands, Norway, Portugal, Spain, Sweden, and Switzerland. Eastern Europe is all European countries to the east of the Elbe, including Russia and excluding Turkey. All averages are weighted by population, using numbers from McEvedy and Jones (1978).
} 
there was considerable divergence. While urbanization in Western Europe grew by almost a factor of 2.5, there was a substantially slower increase in Eastern Europe, and either stagnation or decline in Asia (though the information on Asia is generally less reliable).

Panel B of Figure 1 shows that these differential trends are due in large part to the growth of Atlantic traders. The rest of Western Europe had a relatively high average urbanization rate of 10 percent in 1300 (and 11.4 percent in 1500), but grew at approximately the same rate as Eastern Europe from 1500 to 1850, by a factor of less than 2, to reach 17.0 percent in 1850. In contrast, Atlantic traders started with a lower average urbanization rate of 8.0 percent in 1300 (and only 10.1 percent in 1500), which almost tripled in the subsequent 550 years to reach 24.5 percent in 1850 , overtaking average urbanization in the non-Atlantic parts of Western Europe between 1600 and 1700 (see also Table 1).

Figure 2 Panels A and B show the same pattern using Maddison's estimates of GDP per capita. While GDP per capita rose by a factor of almost 2 among Atlantic traders between 1500 and 1820, in the rest of Western Europe it grew at approximately the same rate as in Eastern Europe, just under 30 percent.

The patterns depicted in Figures 1 and 2 do not reflect the fact that more successful nations engaged in Atlantic trade. There is no differential growth by Atlantic traders before the opening of Atlantic sea routes, and below we show similar results using a measure of access to the Atlantic - ratio of Atlantic coastline to land area - rather than the distinction between Atlantic traders and non-traders. Nor do the results reflect some post-1500 advantage of all coastal nations: Atlantic ports grew much faster than other European cities, while Mediterranean ports grew at similar rates to inland cities.

The evidence suggests that the growth of Atlantic traders played a central role in the growth of Western Europe. In fact, the Rise of Europe between 1500 and 1850 is largely the Rise of Atlantic Europe, and is quite different in nature from pre-1500 European growth. This pattern weighs against theories that emphasize the continuity between pre-1500 and post-1500 European growth and link the Rise of Europe to certain distinctive European characteristics, such as culture, religion, geography or features of the European state system. ${ }^{4}$ Instead, this pattern at first appears consistent with

\footnotetext{
${ }^{4}$ See, e.g., Weber (1905), White (1962), Jones (1981), Hall (1985), Mann (1986), Diamond (1997) and Landes (1998). Notice, however, that the interaction between these characteristics and Atlantic trade could have been important. In fact, our hypothesis emphasizes the interaction between Atlantic trade and pre-existing institutions.
} 
theories that emphasize the importance of profits made in Atlantic trade, colonialism and slavery. ${ }^{5}$ However, other evidence suggests that overseas trade and the associated profits were not large enough to be directly responsible for the process of growth in Europe. Engerman (1972) and O'Brien (1982) demonstrate that the contribution of profits from slavery and trade with the rest of the world to European capital accumulation is modest. O'Brien (1982, p. 2) writes that trade with these regions "... could in no way be classified as decisive for economic growth of Western Europe". So on the basis of available evidence it appears that Atlantic trade could not have driven European growth solely through its direct impact on profits or resources.

We advance the hypothesis that West European growth during this period reflects the combination of growth opportunities offered by the Atlantic and the emergence of economic institutions providing secure property rights to a broad cross-section of society and allowing free entry into profitable businesses. These economic institutions, in turn, resulted from the development of political institutions constraining the power of the monarchy and other established groups allied with the monarchy. We refer to this cluster of political and economic institutions as "capitalist institutions". We further argue that capitalist institutions needed the nascent bourgeoisie to gain strength and that Atlantic trade contributed to economic change indirectly by enriching segments of the bourgeoisie and inducing institutional change. Hence, our answer to the question of "why in Europe" and "why beginning in the 16th century" emphasizes the effect of international trade on institutional development. From 1500, and especially from 1600, onwards, the rise in Atlantic trade strengthened new commercial interests and enabled them to demand and obtain the institutional changes necessary for capitalist growth. ${ }^{6}$ Although profits from Atlantic trade were small relative to GDP, they were still substantial, and most likely much larger than previous trading profits. For example, Figure 3 shows that by the end of the 17th century, the volume of Atlantic trade was much larger than that of long-distance Mediterranean trade. ${ }^{7}$ The recipients of these profits became very rich by

\footnotetext{
${ }^{5}$ For example, Williams (1944), Frank (1978), Wallerstein (1974-1980), Blaut (1993), Pomeranz (2000).

${ }^{6}$ The argument that Atlantic trade strengthened European commercial interests does not imply that without Atlantic trade, the European bourgeoisie would not have eventually secured the development of capitalist institutions. We are therefore not suggesting a mono-causal explanation for the Rise of Europe, but rather suggesting that Atlantic trade played a major role.

${ }^{7}$ See the Appendix for the construction of the Atlantic trade and Mediterranean trade measures. The Mediterranean trade measure excludes short haul coastal trade and trade by the British and Dutch; these countries also engaged in Mediterranean trade as they built their naval power and trading empires after 1600. Supporting our comparison between Atlantic trade and Mediterranean trade is the contrast
} 
the standards of 17th- and 18th-century Europe, and typically politically and socially very powerful. We argue below that they also played an important role in the emergence of British and Dutch capitalist institutions. Consistent with this, we document a strong empirical relationship between Atlantic trade and institutional change.

In our hypothesis, a key link is the strengthening of merchants as a result of the profits from Atlantic trade. Initial institutions constraining monarchies and allowing relatively free entry into overseas trading activities are necessary for merchants and new groups to profit from Atlantic trade, and to induce institutional change. Therefore, our hypothesis predicts an important interaction between initial institutions and Atlantic trade. The data are consistent with this prediction. In Britain and the Netherlands, new groups of merchants benefited from Atlantic trade and played a major role in inducing institutional change, unleashing a much larger economic potential from the rest of the society. In contrast, in Spain and Portugal, the monarchy and loyal groups with royal trading monopolies were the major beneficiaries of early profits from Atlantic trade and plunder because the monarchy was both strong and in tight control of the monopoly of trade.

At this level, our hypothesis on the origins of the Rise of Europe and our explanation for the new fact we document in the first part of the paper are speculative, and much more work is needed to compare our hypothesis to alternatives. Nevertheless, the main facts in this paper, the importance of the growth of Atlantic traders in the early development of European nations and the presence of a significant interaction between Atlantic trade and initial institutions, are important for understanding the Rise of Europe, and future theories need to address these patterns, even if they disagree with our interpretation.

The patterns of West European growth we document in this paper are consistent with the emphasis of a number of historians, including, among others, Cipolla (1965), Davis (1973a), de Vries (1984), Bairoch (1988), Braudel (1992), and de Vries and van der Woude (1997). Nevertheless, we are unaware of any other studies documenting the quantitative importance played by Atlantic traders and Atlantic ports, or showing that the differential growth of Western Europe is largely accounted for by the growth of Atlantic traders.

between Dutch profits from Baltic and Asian trades. The Baltic trade is widely recognized to have been important for the Dutch in the 16th century, but de Vries and van der Woude (1997) estimate that the annual profits of the Dutch East India Company alone between 1630 and 1670 were more than twice the total annual profits from Baltic trade between 1590 and 1599 (pp. 373 and 447). 
On the theoretical side, our interpretation is one where institutional change, even when socially beneficial, will be resisted by some social groups because it will reduce their economic rents, and because groups that gain from the process of institutional change cannot commit to compensate the losers. Accordingly, the process of institutional change involves significant conflict between different groups, in particular the rulers, the elite, and groups receiving privileges from the rulers on the one side, and the citizens at large or new groups, such as the nascent European bourgeoisie, on the other (see North, 1981, Olson, 1982, Krusell and Rios-Rull, 1996, Parente and Prescott, 2000, Acemoglu and Robinson, 2000b, 2002, Rajan and Zingales, 2000). Rogowski (1989) is also related, since he links political coalitions to factor prices, which are in turn determined by the patterns of trade, though he does not focus on how trade might lead to the emergence of capitalist institutions by strengthening the bourgeoisie. Our approach could also be viewed as a "marriage" between the emphasis placed by Marxist historians on the rise of the bourgeoisie and the development of the world economy (e.g., among others, Williams, 1944, Gunder Frank, 1978, Wallerstein, 1974-1980, and Hobsbawm, 1999) and the emphasis on the development of capitalist institutions and secure property rights in Western Europe by North and Thomas (1973), North (1981) and De Long and Shleifer (1993). We agree with North and Thomas (1973, p. 1) who argue that "the development of an efficient organization in Western Europe accounts for the rise of the West". Distinct from these approaches, however, we offer an explanation based on the interaction between Atlantic trade and the development of capitalist institutions for why strong private property rights emerged in Western Europe, especially in Britain and the Netherlands, and starting in the 16 th century. ${ }^{8}$

The rest of the paper is organized as follows. Section 2 documents the key fact of the paper, and shows that the pattern seen in Figure 1 and 2 is robust. Section 3 develops our

\footnotetext{
${ }^{8}$ North and Thomas, following Postan (1975), emphasize the importance of demographic factors, particularly the Black Death, in the transition from feudalism to capitalism. Yet population declines had occurred before the 14th century, and as Brenner (1977) emphasizes, population collapse in Eastern Europe led to a reintensification of feudalism rather than to capitalism. Moreover, even if one accepts the demographic view, since the general trends in population were similar in much of Europe, it would not explain why more capitalistic institutions emerged in Atlantic nations, and especially in Britain and the Netherlands, and not in other places in Europe.

North and Thomas also suggest that Britain and the Netherlands were the first to escape from the "Malthusian trap" because of historical differences in political institutions, such as the strength of the British parliament. Like them, we too emphasize differences in initial political institutions. However, our results suggest that these in themselves were insufficient to account for differences in subsequent development. Instead, it was the interaction between initial institutions and Atlantic trade that was crucial for the Rise of Western Europe.
} 
hypothesis for the Rise of Europe and the role played by Atlantic trade in this process. In this section, we also provide historical evidence supporting our interpretation. In Section 4, we introduce quantitative measures of European institutions for the period between 1300 and 1850, and show that their evolution is closely linked to Atlantic trade. Section 5 documents our second main empirical finding that there is an important interaction between initial institutions and Atlantic trade. Section 6 concludes. The Data Appendix gives details about the construction of all the variables that are used in the paper and various data sources.

\section{Atlantic Trade and the Rise of Europe}

We now present evidence showing that the takeoff of Western Europe after 1500 is largely accounted for by rapid growth among Atlantic traders and nations with easy access to the Atlantic. We also present evidence on city growth, documenting the important role played by Atlantic ports in the urban expansion of Western Europe.

\subsection{DATA}

We use three data series to measure prosperity. First, we construct estimates of urbanization based on the urban population numbers of Bairoch, Batou and Chèvre (1988). This is a comprehensive dataset with information on all 2,200 European cities which had, at some time between 800 and 1800, 5,000 or more inhabitants. These data begin in 800, and there are estimates for every 100 years until 1700, then for every 50 years through 1850. However, Bairoch, Batou and Chèvre (1988) emphasize that estimates before 1300 are rough and less reliable (and they skip the year 1100 due to lack of information). We use these data as our measure of urban population and divide by the population estimates of McEvedy and Jones (1978) to calculate urbanization. We also use estimates of urbanization rates for Asia from the quantitative and qualitative assessments of Bairoch (1988).

Bairoch (1988, Ch. 1) and de Vries (1976, p. 164) argue that only areas with high agricultural productivity and a developed transportation network could support large urban populations. In addition, in Acemoglu, Johnson and Robinson (2002) we presented evidence that both in the time-series and the cross-section there is a close association between urbanization and income per capita before as well as after industrialization. We therefore take urbanization as a proxy for GDP per capita. 
Second, we use estimates of GDP per capita from Maddison (2001). These estimates start in 1500, and are available for 1600, 1700, 1820 and then more frequently. Note that these estimates are no more than educated guesses, especially before 1820 . We therefore think of these GDP data as a check on our results using urbanization data.

Third, we use the European city-level data from Bairoch, Batou and Chèvre (1988). Again, we use their data beginning in 1300 to investigate which urban centers were driving demographic and economic growth, and also to contrast the growth of Atlantic ports to other European ports and to inland cities. We also construct measures of non-Atlantic urban population to investigate the indirect effects of the Atlantic trade on other economic activities and urban expansion in non-Atlantic areas. More detailed discussion of data sources is given in the Appendix (see Appendix Table 1 for variable definitions and Appendix Table 2 for the key data.)

Table 1 gives the estimates of urbanization and income per capita at various dates. The first column is for the whole sample and is unweighted. The second column is weighted by population in the corresponding year, giving a better sense of the aggregate changes. The remaining columns give weighted means for Atlantic traders (nations directly involved in Atlantic trade and colonialism, i.e., Britain, France, the Netherlands, Portugal and Spain), and for non-Atlantic West European countries (Austria, Belgium, Denmark, Finland, Germany, Ireland, Italy, Norway, Sweden and Switzerland), for Eastern European countries and for the Asian countries in our sample. ${ }^{9}$ These numbers confirm the patterns shown in Figures 1 and 2. In the regression analysis, we will report both weighted and unweighted results. The bottom third of the table also gives our estimates of constraint on the executive, which we will use to measure institutions. This variable is described in greater detail and used in Section 4.

\subsection{Economic Growth in Europe}

We start with data on cross-country differences in economic development. Our main measure of economic prosperity is the urbanization rate in the country. Figures $1 \mathrm{~A}$ and 1B above show the evolution of urbanization rates in Western and Eastern Europe, and

\footnotetext{
${ }^{9}$ We take current countries as the unit of observation. Of course, these do not always correspond to the independent polities at the time. For example, during the period of investigation, Italy was not a single nation, but consisted of many city-states. If we had data on each Italian city-state, their average would show the same pattern as our single Italy observation (presuming that our data for the aggregate of Italy are accurate), but because of the larger number of observations, the standard errors would be smaller. The analysis of city-level growth in Section 2.4 below is informative on differential growth across historical political boundaries.
} 
contrast the behavior of Atlantic traders - nations directly involved in Atlantic trade and colonialism - vs. non-Atlantic traders. We first look at Atlantic traders since the main beneficiaries of the opportunities offered by the Atlantic should be those countries that engaged in Atlantic trade and colonialism. However, whether or not a country is an Atlantic trader is clearly endogenous. For this reason, we also present results using a measure of access to the Atlantic, which is a country-level geographic characteristic.

We can test the idea that West European growth after 1500 was due primarily to growth in countries involved in Atlantic trade or with a high potential for Atlantic trade more formally using regressions of the following form:

$$
u_{j t}=d_{t}+\delta_{j}+\sum_{t \geq 1600} \alpha_{t} \cdot W E_{j} \cdot d_{t}+\sum_{t \geq 1500} \beta_{t} \cdot P A T_{j} \cdot d_{t}+X_{j t}^{\prime} \cdot \gamma+\varepsilon_{j t}
$$

where $u_{j t}$ is urbanization (percent of the population living in urban areas) in country $j$ at time $t$, and $W E_{j}$ is a dummy indicating whether the country is in Western Europe, the $d_{t}$ 's denote year effects and the $\delta_{j}$ 's denote country effects, $X_{j t}$ is a vector of other covariates, and $\varepsilon_{j t}$ is a disturbance term. In addition, $P A T_{j}$ is an indicator for Atlantic trader (Britain, France, the Netherlands, Portugal and Spain) or a measure of the potential for Atlantic trade (in both cases, a time-invariant characteristic of the country). The notation $\sum_{t \geq 1500}$ stands for a full set of interactions after 1500 . Since our focus is on the rise of Western Europe as a whole, our basic regressions are weighted by population in each year, but we also report unweighted regressions for completeness.

Columns 1 and 2 of Table 2 only include the interaction terms between the Western Europe dummy and the post-1600 dates, $\sum_{t \geq 1600} \alpha_{t} \cdot W E_{j} \cdot d_{t}$, capturing the differential growth of Western European countries relative to Eastern Europe. The top row reports the p-value from the F-test of the joint significance of these interactions. Column 1 includes data only for 1300-1850, while column 2 extends the sample back to 1000 . Consistent with Figure 1A, both specifications show significantly faster growth in Western Europe than in Eastern Europe. For example, the point estimates (not shown in the table to save space) indicate that in the specification of column 1, West European urbanization grew by 6.9 percentage points relative to East European urbanization between 1500 and 1850 .

Column 3 allows differential growth for countries engaged in Atlantic trade, as captured by the term $\sum_{t \geq 1500} \beta_{t} \cdot P A T_{j} \cdot d_{t}$ (we include 1500 to enable a "specification check" on the timing of the effects). We start with $P A T_{j}$ as a dummy for being an Atlantic 
trader. Significant (and positive) estimates of $\beta_{t}$ 's imply that Atlantic traders grew faster in the post-1600 era. The estimates confirm the pattern seen in Figure 1B, and show large effects from the interaction between the post-1600 dates and the Atlantic trader dummy (these effects become statistically significant after 1750; in columns 8-10, the effects are statistically significant starting in 1700). For example, the estimate for 1850, $\beta_{1850}=0.085$, implies that urbanization among Atlantic traders grew approximately by 8.5 percent more than in other Western and Eastern European nations. Notice also that the estimate of $\beta_{1500}$ in this column, which measures the differential growth of Atlantic traders between 1300-1400 and 1500, is insignificant and small. This is reassuring; since Atlantic trade was very small before 1500, this finding shows that there is no differential growth for Atlantic traders before Atlantic trade actually became important.

Consistent with the patterns shown in Figure 1B, the inclusion of the Atlantic trade interactions explains almost the entire differential growth of West European nations relative to Eastern Europe. The $\sum_{t \geq 1600} \alpha_{t} \cdot W E_{j} \cdot d_{t}$ terms are no longer statistically significant, and the point estimates (not shown in the table) imply that West European urbanization grew only by 2.9 percentage points relative to Eastern Europe between 1300-1500 and 1850 as opposed to 6.9 percentage points in column 1.

Column 4 reports similar results for the 1000-1850 period. Here the interaction between the West European dummy and the post-1500 dates is significant at the 10 percent level, which reflects the lower level of East European urbanization in the base period, which is now 1000-1400. Column 5 reports unweighted results. Here the Western Europe interaction terms with post-1600 dates are even less significant. Column 6 includes Asian countries. This has little effect on the estimates of the differential growth of Atlantic traders, but now West European countries are growing faster relative to the control group, which includes Asian countries (see Figure 1A). ${ }^{10}$ Finally, Column 7 excludes Britain from the sample. This is useful since Britain is the fastest growing country over this period, and it is of interest to know whether the results simply reflect British growth. The estimates in column 7 are about half the size of those in the other columns, but they show the same pattern.

An important concern with the results reported so far is that who became an Atlantic

\footnotetext{
${ }^{10}$ O'Rourke and Williamson (2002) argue that as China withdrew from world trade, this freed up Asian supply for export to Europe, contributing to European growth. Galor and Mountford (2002) argue that international trade has played an important role in the divergence between Europe and Asia by inducing European economies to specialize in the production of skill-intensive goods with greater technological progress, while Asian economies specialized in labor-intensive goods. See also Lucas (1988).
} 
trader was endogenously determined. It may be that only countries with high growth potential - or those that were going to grow anyway - engaged in substantial Atlantic trade and colonial activity. For example, Belgium, Ireland, Denmark, Germany and Norway also had access to the Atlantic, either directly or via the North Sea. But they did not take part in long distance oceanic trade. It may therefore be preferable to use a measure of potential access to the Atlantic as our time-invariant $P A T_{j}$ variable. In columns 8, 9 and 10, we use the measure of Atlantic coastline-to-area ratio. ${ }^{11}$ The reasoning is that Atlantic trade can potentially play a more important role in the growth of countries with more Atlantic coastline relative to their size. In constructing the Atlantic coastline-to-area ratio, we give positive Atlantic coastline-to-area numbers for Denmark, Germany and Norway. We choose this coding since it is less favorable to our hypothesis - these three countries did not engage in much Atlantic trade and did not grow rapidly until the 19th century.

The results using the coastline-to-area measure for $P A T_{j}$ are similar to those using the Atlantic trader dummy. For example, in column 8, the interactions between the West European dummy and post-1600 dates are significant only at the 9 percent level, and much smaller than those in column 1. The point estimates imply that West European urbanization grew only by an additional 2.7 percentage points over East European urbanization, from 1500 to 1850, as opposed to 6.9 percentage points in column 1 .

On the other hand, the differential growth related to the Atlantic, now captured by the interactions with the Atlantic coastline-to-area ratio, is still strong; the point estimates for the $\beta$ 's are significant starting in 1700, and quantitatively large. For example, the coefficient $\beta_{1850}=5.05$ indicates approximately 6.5 percentage points more urbanization growth in the Netherlands than in Italy between 1300-1400 and 1850 (the Atlantic coastline-to-area ratio for the Netherlands is 0.013 and for Italy it is 0 ). This explains over half of the differential 12 percentage point actual urbanization growth between Italy and the Netherlands between these two dates. ${ }^{12}$ Other specifications

\footnotetext{
${ }^{11}$ Alternatively, we could use the Atlantic coastline-to-area measure as an instrument for the Atlantic trader dummy. The results we report can be thought of as the reduced form for this IV strategy (a univariate regression of the Atlantic trader dummy on the coastline-to area measure in our sample has an $\mathrm{R}^{2}$ of 0.30 ). However, it is more plausible to think that, even conditional on being an Atlantic trader, a country with greater Atlantic coastline will also trade and grow more than another with less coastline. So we prefer to focus on the regressions here, rather than IV regressions.

Information on the length of coastline and the land area of particular countries is taken from Integrated Coastline Management (on the web at http://icm.noaa.gov/country/ICM-pro.html), which reports a standardized measure. We use only Atlantic coastline, i.e., omitting any coast in the Mediterranean or the Baltic. Details are provided in the Appendix.

${ }^{12}$ Notice that the fit of the models with the Atlantic coastline-to-area ratio is somewhat better than
} 
using the Atlantic coastline-to-area measure in columns 9 and 10 give similar results. Finally, column 11 uses another measure for $P A T_{j}$, average fraction of the population living in Atlantic ports, which again proxies for the importance of Atlantic ports relative to the size of the country. The results are once more similar.

The results reported in Panel A of Table 2 are from estimating equation (1), which allows for an arbitrary pattern of differential growth in Atlantic traders. One might conjecture that the differential growth of Atlantic traders should be related to the volume of Atlantic trade. For this reason, in Panel B we report results from estimating a "structured" model of the form:

$$
u_{i t}=d_{t}+\delta_{j}+\sum_{t \geq 1600} \alpha_{t} \cdot W E_{j} \cdot d_{t}+\beta \cdot P A T_{j} \cdot \ln A T_{t}+X_{j t}^{\prime} \cdot \gamma+\varepsilon_{j t},
$$

where $A T_{t}$ denotes our estimate of the aggregate volume of European Atlantic trade, shown in Figure 3 above. The construction of this variable is explained in the Appendix, where we also provide alternative measures. Appendix Table 3 shows regression estimates using the main alternative measure based on the work by O'Rourke and Williamson (2002), with very similar results to those reported here. Note that the model in equation (2) is more restrictive than that in (1), since we are forcing the pattern of $\beta_{t}$ 's in (1) to be the same as that of $\ln A T_{t}$. In all columns, the estimate of $\beta$, the coefficient on the interaction term between the log volume of Atlantic trade and potential for Atlantic trade at the country level, is highly significant, while the interaction terms between Western Europe and post-1600 dates are again insignificant. Notably, the $\mathrm{R}^{2}$ of this more restrictive regression is close to the $\mathrm{R}^{2}$ of the flexible specifications reported in Panel A. Using the Atlantic trader dummy in column 3, the $\mathrm{R}^{2}$ is 0.89 with the flexible specification and 0.88 with the structured specification, while using the Atlantic coastline-to-area ratio (column 8), the two $\mathrm{R}^{2}$ 's are 0.94 and 0.92 respectively. These results suggest that that the interaction between potential for Atlantic trade and post-1600 dates is likely capturing the importance of Atlantic trade, not some other parallel process. Finally, Appendix Table 4 reports estimates from a model similar to (2), except that we use the interaction between $P A T_{j}$ and estimates of (log) Atlantic trade by country $j .{ }^{13}$ The results are very similar to those reported in Table 2.

those with the Atlantic trader dummy. The former measure includes Belgium, Germany and Denmark, which did not grow very rapidly over this time period, as potential Atlantic traders, but also gives greater potential for trade to Britain and the Netherlands, which have relatively high coastline-to-area ratios.

${ }^{13}$ More formally, we use $P A T_{j} \cdot \max \left\{0, \ln A T_{j t}\right\}$ where $A T_{j t}$ is our estimate of Atlantic trade undertaken by country $j$ at time $t$. The max operator avoids the "log of 0 " problem. 
Table 3 provides regression evidence illustrating the same pattern using estimates of GDP per capita from Maddison (2001). In the top panel, we report estimates from flexible models of the following form:

$$
\log y_{j t}=d_{t}+\delta_{j}+\sum_{t \geq 1600} \alpha_{t} \cdot W E_{j} \cdot d_{t}+\sum_{t \geq 1600} \beta_{t} \cdot P A T_{j} \cdot d_{t}+X_{j t}^{\prime} \cdot \gamma+\varepsilon_{j t},
$$

where $y_{j t}$ is income per capita in country $j$ at time $t$. As before, $W E_{j}$ is a dummy indicating whether the country is in Western Europe, the $d_{t}$ 's denote year effects and the $\delta_{j}$ 's denote country effects, $X_{j t}$ is a vector of other covariates, and $\varepsilon_{j t}$ is a disturbance term. In addition, $P A T_{j}$ is again either a dummy for Atlantic trader or the Atlantic coastline-to-area ratio. Maddison (2001) reports GDP per capita for 1500, 1600, 1700, 1820 and 1870. We take 1500 as the base year, and add interactions between our measure of potential for Atlantic trade, $P A T_{j}$, and the post-1600 dates to capture the importance of Atlantic trade for the country (so we cannot conduct a specification test for pre-existing trends using the interaction between $P A T_{j}$ and 1500). Output numbers for 1870 are already heavily influenced by differential industrialization experiences of various countries, so our baseline specification stops in 1820 . For completeness, we also report regressions that extend the sample to 1870 .

Parallel to our results in Table 2, West European countries grow faster after 1500, though this pattern is somewhat less pronounced, especially when we limit the sample to 1500-1820. The interactions between the Atlantic trader dummy and the post-1600 dates are typically significant starting either in 1600 or 1700 and quantitatively large. For example, the estimate of $\beta_{1820}=0.27$ in column 3 indicates that Atlantic traders grew, on average, 31 percent $(\approx 0.27 \log$ points) more than non-Atlantic trader West European nations between 1500 and 1820 . Columns 4-7 report similar results to those in Table 2. The pattern is the same when the sample is extended to 1870 , with unweighted regressions, when Britain is excluded from the sample, and when Asian countries are included. Columns 8-11 report similar results using the Atlantic coastline-to-area measure and the fraction of the population living in Atlantic ports.

Panel B of the Table 3 reports structured models similar to (2) where instead of flexible interactions between time dummies and $P A T_{j}$, we include the structured interaction term, $\beta \cdot P A T_{j} \cdot \ln A T_{t}$. Thus the estimating equation is now:

$$
\log y_{j t}=d_{t}+\delta_{j}+\sum_{t \geq 1600} \alpha_{t} \cdot W E_{j} \cdot d_{t}+\beta \cdot P A T_{j} \cdot \ln A T_{t}+X_{j t}^{\prime} \cdot \gamma+\varepsilon_{j t} .
$$


This more restrictive specification again shows that the differential growth of Western Europe after 1600 is closely linked to the rise of Atlantic traders.

Overall both Table 2 and Table 3 show the same pattern: when the effect of Atlantic trade is not taken into account, the estimates of $\alpha_{t}$ 's are significant, positive and largeWestern Europe is growing faster than Eastern Europe. Once Atlantic trade interactions are included, $\alpha_{t}$ 's are either no longer significant or are, at the very least, reduced substantially, while the effect of Atlantic trade is very strong. We interpret this as evidence that the differential growth of Western Europe over this time period is driven by growth in countries that were engaged in Atlantic trade. Also noteworthy is that the more restrictive specifications (2) and (4) give essentially identical results and very similar $\mathrm{R}^{2}$ 's to the flexible specifications, lending further support to the notion that these interactions are linked to Atlantic trade. ${ }^{14}$

\subsection{Other Determinants of Economic Performance}

The models in Tables 2 and 3 do not control for other potential determinants of economic performance. To check the robustness of our results, Table 4 adds covariates to our basic regressions, including interactions between country religion and time, the incidence of wars, interactions between Roman heritage and time, and interactions between latitude and time. The overall patterns are not affected. To save space, Table 4 only reports the structured specifications of equations (2) and (4).

Weber (1905) and Landes (1998) argue that religion is an important determinant of economic and social development. To assess the importance of religion, we allow Protestant countries to grow at a rates different than non-Protestant countries by interacting a dummy for being a majority Protestant country in 1600 with year dummies from $1600 .^{15}$ The p-values from the joint significance test reported in columns 1 of Panels A and C

\footnotetext{
${ }^{14}$ It is also worth noting that our findings are consistent with Allen's (1998) numbers on the real wages of building craftsmen and laborers in a range of European cities. He finds that between 1500 and 1750, real wages fell in most cities, but remained roughly constant in London, Amsterdam and Antwerp.

${ }^{15}$ We use the historical encyclopedia of Langer (1972) as the basis for coding our religion variables (checking for more updated information in Stearns, 2001). The following countries were majority Protestant in 1600: Britain, the Czech Republic, Denmark, Finland, the Netherlands, Norway, Sweden, Switzerland. Germany was largely Protestant, but the balance between Protestant and Catholic remained unclear until the end of the 1600s. The specification reported in our regression tables codes Germany as Protestant in 1600, but we have also tried coding Germany as Catholic. We have also tried a more complete alternative specification in which religion is coded directly as Catholic, Muslim, Orthodox or Protestant, with essentially identical results.
} 
show that when the dependent variable is the urbanization rate, these interactions are either marginally significant or insignificant. In contrast, when the dependent variable is log GDP per capita and we use the Atlantic trader dummy for our potential Atlantic trade measure (Panel B), there is a significant effect from these religion $\times$ year interactions. Nevertheless, this has little impact on the pattern of differential growth between Western and Eastern Europe, or between Atlantic and non-Atlantic trader. Moreover, the quantitative effects of Protestantism on economic growth are considerably smaller than those of Atlantic trade. The point estimates (not reported) imply that Protestant countries experienced 4.5 percentage points greater urbanization growth between 1500 and 1850, and 30 percent more GDP growth between 1500 and 1820. The corresponding numbers for Atlantic traders in the flexible specifications including the Protestant times post-1600 interactions are 8.4 percentage points more urbanization and 41 percent more GDP growth.

Following the work by Hintze (1970) and Tilly (1990), many political scientists view war as an important factor in the process of state building and subsequent economic development. The basic idea is that countries that fight many wars will develop an effective state apparatus and bureaucracy, and this will facilitate economic development. Incidence of wars might also proxy for the importance of inter-state competition, which many historians, including Jones (1981), Mann (1986 and 1993), Hall (1985), and Mokyr (1990), have emphasized. To assess the importance of wars, in columns 2 and 6 we include a variable which is the average number of years with war during the previous period (a century or half century). ${ }^{16}$ We find that this variable itself is insignificant in the urbanization regressions and has no effect on the patterns documented so far.

A number of historians including, Jones (1981) and Landes (1998), see the roots of Western European growth in the Roman Empire (see also Anderson, 1974a), and perhaps in the culture of Ancient Greece. To investigate whether Roman heritage is important for the Rise of Europe, we created a dummy that indicates whether a country was part of the Roman Empire. ${ }^{17}$ We then interacted this variable with dates from 1600

\footnotetext{
${ }^{16}$ Kohn (1999) documents European wars from about 1000AD. He lists the dates of each war, together with a brief explanation of participants, duration and intensity. We exclude purely civil wars and colonial wars that took place outside of Europe. We calculate the average number of years of war in a time interval before each date in our dataset: for the preceding 100 years through 1700 and for the preceding 50 years for 1750,1800 , and 1850. We have experimented with alternative codings (e.g., dropping "minor" wars), but our main results are not affected. Kohn (1999) does not appear to provide reliable information on the wars of Finland and Greece during this period, so we drop these countries from regressions involving the "wars per year" variable.

${ }^{17}$ Coded from Langer (1972). Any country that was ever part of the Roman empire receives a value of
} 
to see whether there is differential growth depending on the extent of Roman heritage (columns 3 and 7). These interactions are typically insignificant, and do not affect the patterns reported in the previous tables. The only exception is when we use log GDP per capita as the dependent variable and the Atlantic trader dummy for $P A T_{j}$. But in this case, the results indicate that countries with Roman heritage grew more rapidly between 1400 and 1600, and significantly slower thereafter.

Finally, in columns 4 and 8 we add interactions between distance from the equator (measured as the absolute value of the latitude of the nation's capital) and dates from 1600 to see whether the move of economic activity away from Southern Europe towards Northern Europe can explain the rise of Atlantic nations. Once again the addition of these variables does not affect the importance of Atlantic trade, and the latitude interactions are typically insignificant (except in Panel B where, as before, the point estimates do not indicate that countries with higher latitudes grew faster over the whole time period).

\subsection{Urban Expansion and Atlantic Ports}

We next turn to the analysis of data on the population of individual cities compiled by Bairoch, Batou and Chèvre (1988). This analysis is useful for four distinct reasons. First, it will act as a check on our findings from county-level data. Second, since a number of the countries we are treating as single observations in our cross-country analysis previously consisted of distinct polities, city-level analysis provides an opportunity to capture this type of within "country" variation. Third, it will show that Atlantic ports played an important role in the urban and economic expansion of Atlantic traders and nations, substantiating that the patterns documented in Tables 2, 3 and 4 are related to Atlantic trade. Finally, by exploiting the differential growth patterns of Atlantic and Mediterranean ports, we document that the post-1500 developments in Western Europe are related to Atlantic trade, not simply to the growth of overall trade.

Figure 4 shows that the urban expansion of Western Europe was driven by cities that were Atlantic ports. Figure 5 depicts the behavior of Atlantic ports and Mediterranean ports, and shows that Mediterranean ports over this time period grew at similar rates

one; other countries receive a value of zero. The following countries had a "Roman Heritage" according to this source: Belgium, Britain, France, Italy, the Netherlands, Portugal, Spain, and Switzerland. In our base case we do not include Bulgaria, Greece, Romania, Yugoslavia, as these countries arguably had their Roman traditions eradicated by a long period of Ottoman rule. Including this set of countries weakens the "Roman Heritage" effect further. 
to inland West European cities, while Atlantic ports grew much faster. ${ }^{18}$

The rest of this subsection documents these results using regression analysis. Table 5 estimates models of the following form:

$$
\log U_{i t}=d_{t}+\delta_{i}+\sum_{t \geq 1600} \alpha_{t} \cdot W E_{i} \cdot d_{t}+\sum_{t \geq 1500} \beta_{t} \cdot A P_{i} \cdot d_{t}+X_{i t}^{\prime} \cdot \gamma+\varepsilon_{i t},
$$

where $U_{i t}$ is urban population in city $i$ at time $t, W E_{i}$ is a dummy indicating whether the city is in Western Europe, and $A P_{i}$ is a dummy indicating whether the city is an Atlantic port, or in our alternative specification, whether it is a potential Atlantic port. ${ }^{19}$ The $d_{t}$ 's denote year effects and the $\delta_{i}$ 's denote city effects, $X_{i t}$ is a vector of other covariates, and $\varepsilon_{i t}$ is a disturbance term. The Atlantic port times 1500 interaction is again included to allow a specification test on the timing of the rise of Atlantic ports. The sample for all regressions in Table 5 is the balanced panel of cities for which we have observations in each date. ${ }^{20}$ We report regressions weighted by population as well as unweighted regressions. We start with data from the Bairoch et al. data set, so exclude data from Asian cities; we then add data for 10 Asian cities for the whole period from Chandler (1987).

In column $1, A P_{i}$ is a dummy for Atlantic port. The interaction terms between the Atlantic-port dummy and the post-1500 dates, i.e., the $A P_{i} \cdot d_{t}$ terms, are positive and statistically and economically very significant. For example, the coefficient of 0.79 on the interaction between the Atlantic-port dummy and the 1800 dummy implies that Atlantic ports grew approximately 120 percent $(\approx 0.79 \log$ points) relative to other cities between 1300-1400 and 1800. Notably, there appears little differential growth of Atlantic ports before 1600, once again supporting the notion that the growth of these ports is related to the emergence of trading and colonial opportunities via the Atlantic.

In the bottom panel, we report results from a structured specification of the effect

\footnotetext{
${ }^{18}$ Both figures use only the cities in our balanced sample, and are unweighted.

${ }^{19}$ See the Appendix for exact definition and list of Atlantic ports in our panel. In Figures 4 and 5, we use the definition of actual Atlantic port. Belgian, Irish, and German potential Atlantic towns, for example Hamburg and Bremen, which were not involved in Atlantic trade, are not counted as as Atlantic ports. In the regression analysis, we also report results with a dummy for "potential Atlantic port". The distinction between Atlantic port and potential Atlantic port parallels the use of Atlantic trader dummy and our measure of access to the Atlantic in Table 2, 3 and 4.

20 The focus on a balanced panel of cities avoids problems of "composition bias", which would result from the fact that cities enter the data set only once they exceed a certain threshold (typically 5,000 people). For example, if an area is growing rapidly, many cities will also grow in population and exceed the relevant threshold, but the addition of many cities with population around 5,000 will reduce the average population of the cities in this area. We look at a larger sample of cities in Table 7 below.
} 
of Atlantic trade and estimate:

$$
\log U_{i t}=d_{t}+\delta_{i}+\sum_{t \geq 1600} \alpha_{t} \cdot W E_{i} \cdot d_{t}+\beta \cdot A P_{i} \cdot \ln A T_{t}+X_{i t}^{\prime} \cdot \gamma+\varepsilon_{i t}
$$

where recall that $A T_{t}$ is total volume of Atlantic trade. Once again, the estimate of $\beta$ is highly significant, and the $\mathrm{R}^{2}$ of this more restrictive regression is almost the same as the regression reported in the top panel. Column 2 reports a similar regression, but now observations are not weighted. The results are similar, but quantitatively smaller, since large Atlantic ports such as London and Amsterdam are not getting bigger weights.

Columns 3 and 4 report weighted and unweighted estimates from similar models, with a dummy for potential Atlantic port, that is, any city that is in our balanced panel that could have been used as a port for Atlantic trade. The results are similar to those in columns 1 and $2 .^{21}$

Column 5 drops London and Amsterdam to show that the results are not driven by these two major cities. The coefficients on Atlantic port times year interactions are approximately halved from 1700 onwards, but they remain significant. Column 6 adds a full set of country times year interactions to show the differential growth of Atlantic ports relative to other cities in the same country. The coefficients on Atlantic port times year interactions after 1700 are again about half those of column 1, but still highly statistically significant. Column 7 adds Asian cities from Chandler (1987), so now West European cities are being compared to both East European and Asian cities. The results are similar, but also show the differential growth of all West European cities relative to Asian cities. ${ }^{22}$

Is there something special about ports, or is it Atlantic ports that are behaving differently after 1500 ? To answer this question, column 8 estimates the regression:

$$
\log U_{i t}=d_{t}+\delta_{i}+\sum_{t \geq 1600} \alpha_{t} \cdot W E_{i} \cdot d_{t}+\sum_{t \geq 1500} \beta_{t} \cdot A P_{i} \cdot d_{t}+\sum_{t \geq 1500} \beta_{t}^{M} \cdot M E_{i} \cdot d_{t}+\varepsilon_{i t}
$$

\footnotetext{
${ }^{21}$ Note that some of the coefficients on potential Atlantic port are higher than the corresponding coefficients on Atlantic port. This for of two reasons: first, to allow for the specification test discussed in the text, these regressions use 1300-1400 as the base period, and there was rapid growth in a few potential, but not actual, Atlantic ports from 1400 to 1500. Cumulative growth between 1500 and any date is always higher for Atlantic ports than for potential Atlantic ports. Second, some of the potential Atlantic ports flourished as a result of secondary trade from the Atlantic. Edinburgh is a prime example, growing from 18,000 inhabitants in 1500 to 83,000 inhabitants in 1800 . In fact, to be on the conservative side, we coded Edinburgh as a potential Atlantic port, even though it had some involvement in Atlantic trade (partly through the associated port of Leith).

${ }^{22}$ In these specifications, we do not include interactions between an Asian city dummy and the post1500 dates so the comparison group is all East European and Asian cities. Including such interactions has no effect on the results.
} 
where $M E_{i}$ is a dummy for Mediterranean port, allowing the Mediterranean ports to also grow at differential rates. The estimates in column 8 confirm the patterns shown in Figure 5: there is no differential growth of Mediterranean ports, but a very strong Atlantic port effect.

Table 6 parallels Table 4 and adds the same covariates at the city level when available. The results are essentially the same as in Table 4, and none of these variables appear to be significant or affect the pattern that we have documented so far. The only noteworthy difference from Table 4 is that the interaction terms between distance from the equator and post-1600 years are now also significant, especially after 1700, though they do not affect the differential pattern of growth by Atlantic ports. The significance of these interactions presumably reflects the shift of urban populations away from Portuguese and Spanish cities to British and Dutch ports. Recall, however, that these interactions between time and distance from the equator were not significant (or had the wrong sign) in the cross-country regressions.

All the estimates shown so far use a balanced panel of cities. As discussed in footnote 20, this avoids potential "composition biases" due to the addition of smaller cities in later dates. On the other hand, it is important to know whether the importance of Atlantic ports for Western European growth holds in a larger sample of cities. In Table 7, we look at a larger set of cities between four dates 1300, 1500, 1700 and 1800. The sample is larger than the one used in Tables 5 and 6 , since, in those tables the criterion for inclusion was no missing observations at any date between 1300 and 1850. In all columns, the same pattern emerges: there is no differential growth of Atlantic ports between 1300 and 1500, but significantly faster growth between 1500 and 1700, and also between 1500 and 1800. Moreover, as in Tables 6 and 7, allowing differential growth for Atlantic ports explains all of the faster growth of Western Europe relative to Eastern Europe between 1500 and 1700. When Asian cities are included, the Western European effect between 1500 and 1800 is significant even after controlling for Atlantic ports, capturing the fact that Western European cities are growing considerably faster than Asian cities, which now form the comparison group together with East European cities.

\subsection{Non-Atlantic Urban Growth in Western Europe}

Was the urban and economic expansion of Atlantic nations driven solely by growth in Atlantic ports? The answer is yes in some cases, and no in others - and this variation is interesting in its own right, and for the hypothesis we develop below. 
Figure 6 shows the expansion of Iberian (Spanish and Portuguese) Atlantic ports, other Iberian cities, and West European inland cities. The figure shows that almost all of the differential growth of Spain and Portugal comes from Atlantic ports. In fact, non-Atlantic parts of Spain and Portugal grew slower than West European inland cities. This pattern contrasts with that shown in Figure 7: there is steady growth in nonAtlantic parts of Britain and the Netherlands (notice that the non-Atlantic British and Dutch line starts below the Western European line and overtakes it by 1850). It is also worth noting that the growth in British non-Atlantic population starts after the growth spurt of British Atlantic ports (though this cannot be seen in the figure, which combines British and Dutch data). So whatever process was responsible for British and Dutch, but not Portuguese and Spanish growth, appears to be more than the direct effect of growth of Atlantic trade.

Table 8 documents similar patterns using regression analysis. The models that are estimated are similar to (1) and (2), except that the dependent variable is now nonAtlantic urbanization, that is, total urban population in non-Atlantic ports divided by total population. We think of this as a proxy for economic activities that are not directly related to Atlantic trade. Since there were activities in Atlantic ports not related to Atlantic trade, for example in London, this measure is an understatement of these activities, while it will be an overestimate to the extent that some of the nonAtlantic-port activities were driven by Atlantic trade. The specifications are identical to those reported in Tables 2 and 3. They show that there is faster growth in nonAtlantic urbanization (non-Atlantic-related economic activity) among nations trading in the Atlantic or those with greater potential for Atlantic trade. A comparison of the results in Panel A with those in Table 3 shows that the takeoff in these activities postdates the growth of Atlantic ports and overall urbanization.

\subsection{INTERPRETATION}

The evidence presented so far shows an important relationship between the potential for Atlantic trade and post-1500 economic development. This evidence suggests that the opportunities to trade in the Atlantic and via the Atlantic, and the associated profits from colonialism and slavery, played an important role in the Rise of Europe. Almost the entire differential growth of Western Europe over Eastern Europe (but notably not over Asia) is accounted for by the growth of nations directly involved in Atlantic trade or of those with easy access to the Atlantic. This suggests that any theory of the Rise 
of Europe needs to take into account the role of Atlantic trade.

Theories linking the Rise of (Western) Europe to the continuation of pre-1500 trends driven by certain distinctive characteristics of European nations or cultures, such as Roman/Ancient Greek heritage (Landes 1998, and Jones 1981), religion (Landes 1998, and Weber 1993), do not provide a complete explanation. ${ }^{23}$ We will also show in Section 5 that there is no evidence in support of the view that some pre-1500 institutional features can explain the post-1500 developed by themselves.

This brings us to theories linking European growth directly to profits from Atlantic trade or colonialism, in particular to those emphasizing the importance of the transfer of resources from the New World, or at the very least, the contribution of profits from this trade to capital accumulation in Europe. This thesis was first put forward by Williams (1944), and has been developed by dependency theorists such as Gunder Frank (1978) and world-system theorists such as Wallerstein (1974-1980).

The fact that there was a large amount of trade after the discovery of the New World and the Atlantic routes to Asia suggests that there were at least some inframarginal rents from Atlantic trade. So it is undoubtedly true that trade with these areas contributed to European growth. The question is whether it was the decisive factor. Here, quantitative analyses by economic historians, including, among others, Engerman (1972), Engerman and O'Brien (1981), O'Brien (1982), and Bairoch (1993, chapter 5), show that the volume of trade and the profits generated by trade appear to be too small to account for much of European growth directly.

For example, O'Brien (1982) calculates that, under assumptions favorable to the importance of international trade, total profits from British trade with less developed regions of the world during the late 18th century were approximately $£ 5.6$ million, while total gross investment during the same period stood at $£ 10.3$ million. The same numbers during the early 19th century were, respectively, £15.9 million and £34.3 million. During this period, the aggregate savings rate was between 12 and 14 percent, so if we assume that this savings rate also applies to profits from trade, the contribution of profits from trade to aggregate capital accumulation would be between 5.5 and 7.5 percent. Even assuming considerably higher savings rates, the contribution would remain relatively

\footnotetext{
${ }^{23} \mathrm{As}$ an additional piece of evidence against theories emphasizing distinctive characteristics of European nations, the regression results in Tables 4 and 6 offer no evidence that any of these characteristics played a major role in the Rise of Europe (i.e., none of these variables are consistently significant or ever change the overall pattern of rapid Atlantic growth combined with comparable growth between Eastern Europe and non-Atlantic Western Europe).
} 
small.

Atlantic trade may have also played an important direct role by inducing a reallocation of resources within Europe, even if profits from trading were small (as would be the case in a competitive economy). This direct channel is also unlikely to be the whole story, since the volume of trade was small relative to the size of European economies. For example, Bairoch (1993) calculates that commodity trade between Western Europe and the rest of the world amounted to less than 4 percent of the GNP of Western Europe before $1800 .^{24}$

In view of these numbers and other assessments by economic historians, it appears unlikely that the role of Atlantic trade in the Rise of Europe was primarily through the direct effect of increased international trade. This inclines us towards a view in which the Rise of Europe reflects a major social transformation induced by Atlantic trade and colonialism. In this context, the fact that not only Atlantic ports but also other areas in some of the countries engaged in Atlantic trade prospered during the critical periods of European growth and Atlantic trade expansion is relevant. These patterns are suggestive of some indirect process of social change unleashed by Atlantic trade and colonial activity. In the next section, we outline a theory along these lines.

\section{Our Hypothesis}

Our hypothesis is that "Atlantic trade", i.e., the opening of the sea routes to the New World, Africa, and Asia and the building of colonial empires, contributed to the process of West European growth between 1500 and 1850 through its direct economic effects, as well as indirectly by inducing fundamental institutional changes. Atlantic trade enriched and strengthened new groups of merchants. Via this channel, it contributed to the emergence of capitalist institutions, i.e., economic and political institutions friendly to capital, as these merchants demanded and obtained checks on royal power, secure property rights and access to the lucrative commercial opportunities under royal monopoly. ${ }^{25}$ Our hy-

\footnotetext{
${ }^{24}$ Alternatively, Atlantic trade and the profits it generated may have been important because they created major externalities on other sectors, or because there were crucial non-convexities in the production possibilities frontier of European economies at the time. For example, in a model with multiple steady states with different growth rates, a small change may switch the economy from the basin of attraction of one steady state to that of the other (e.g., see, Zilibotti, 1995, or Ciccone and Matsuyama, 1999).

${ }^{25}$ An additional channel via which Atlantic trade may have contributed to institutional change may be the desire of the monarchy to secure the property rights of merchants in order to encourage longterm investments in long distance trade. Although our reading of the relevant history makes us believe that the greater contribution of Atlantic trade to the development of capitalist institutions was by
} 
pothesis also implies that the tendency for capitalist institutions to emerge should have been much stronger in initially non-absolutist societies than in countries with absolutist regimes and monarchy-controlled trade monopolies, because in these latter countries Atlantic trade did not strengthen new merchant groups.

If correct, our hypothesis explains not only the link between Atlantic trade and the Rise of (Western) Europe, but also why it was Britain and the Netherlands, and not Spain and Portugal, that experienced the emergence of capitalist institutions and rapid pre-industrial economic growth. In this section, we spell out this hypothesis in more detail and provide historical evidence to support our interpretation.

\subsection{The Argument}

Our main hypothesis is that the Rise of Europe is due to the direct and indirect effects of Atlantic trade, with the indirect effects working through institutional change demanded, obtained and sustained by new merchant groups enriched by Atlantic trade. This hypothesis can be broken into 4 subhypotheses:

1. Capitalist institutions are essential for the incentives to undertake investments and for sustained economic growth, such as the one experienced by Western Europe during the "First Great Divergence".

2. Capitalist institutions are favored by commercial interests, especially new groups that do not receive trading privileges from the state, but are typically not welcome by the monarchy, rulers and elites.

3. Institutions favored by economically and politically powerful groups are more likely to prevail.

4. Atlantic trade and colonial activity generated substantial growth opportunities, which enriched and strengthened commercial interests, including new groups without ties to the monarchy.

Together these four subhypotheses yield our main hypothesis: Atlantic trade generated growth opportunities and provided substantial profits for a segment of the bourgeoisie in Western Europe, and this group could demand and obtain significant institutional reforms protecting their property rights. With their newly gained property strengthening the bourgeoisie in its fight against the monarchy, the relative roles of the two mechanisms in West European institutional changes is not essential for our overall story. 
rights, the bourgeoisie of West European nations took advantage of the growth opportunities offered by Atlantic trade, invested more, traded more, and fueled the First Great Divergence.

Notice the importance of the fourth subhypothesis - if new commercial groups did not profit from the opportunities offered by Atlantic trade and colonialism, the chain of reasoning would not work. This observation qualifies and refines our hypothesis: major institutional changes are less likely in societies where the monarchy was initially strong and controlled the monopoly of trans-oceanic trade, ensuring that the major beneficiaries from Atlantic profits were the monarchy and groups allied with the monarchy. Therefore, we expect an important interaction between initial institutions and the response of a society to the opportunities presented by Atlantic trade.

We next spell out these subhypotheses in more detail and provide some historical evidence in support of each subhypothesis, with special emphasis on the fourth subhypothesis.

\subsubsection{The emergence of capitalist institutions was essential for Western European growth}

Capitalist institutions, in particular, the political institutions constraining the power of the monarchy, protected the property rights of commercial and industrial capitalists, enabled the entry of new groups into lucrative businesses ${ }^{26}$ and reduced the hold of landed aristocracy on rural labor, potentially increasing the supply of labor to commerce and industrial sectors.

At some level the notion that capitalist growth requires enforcement of property rights is obvious, even to the level of being tautological. Jones quotes the 19th-century historian William Cunningham to forcefully emphasize this point: "A man will not risk what he has in trade, except for the prospect of very large gains, if he is likely to be robbed by pirates, or to be oppressed by the government if he is successful in business" (1981, p. 85). North emphasizes the same point in formulating his theory of European growth: "The most convincing explanation for the Industrial Revolution as an acceleration the rate of innovation is... a combination of better specified and enforced property rights and increasingly efficient and expanding markets... [directing]...

\footnotetext{
${ }^{26}$ In this context, we might view British and Dutch financial system innovations, which facilitated the entry of new investors into long-distance trade, as a component of capitalist economic institutions. See the discussion in Neal (2000).
} 
resources into new channels." (1981, p. 166). North and Thomas (1973, p. 155-6) similarly state: "By 1700 the institutional framework of England provided a hospitable environment for growth ... perhaps most important, the supremacy of parliament and the embedding of property rights in the common law put political power in the hands of men anxious to exploit the new economic opportunities and provided the essential framework for a judicial system to protect and encourage productive economic activity."

Marxist historians, in particular, Dobb (1946), Brenner (1977) and Hobsbawm (1999), also link European growth to the emergence of the capitalist regime, though they do not use the term "institutions" in the sense that North and we do. Similar arguments were subsequently developed in greater detail in the British case initially by Engels (1892), and subsequently by Hill (1969) and Brenner (1973, 1993), as well as non-Marxist historians such as Tawney (1941a,b), Moore (1966), Stone (1972), and Pincus (1998, 2002). These scholars all argue that the evolution of political institutions can be explained by social conflict, itself in part resulting from economic change. These changes gave rise to new groups with commercial or capitalistic interests, the "gentry" and the "bourgeoisie," who fought to change institutions to remove the threat of arbitrary taxation and state predation, and to secure their property rights and the profits from commerce. Hill (1969, p. 13), for example, writes "movements in population and prices were roughly similar all over Europe during this period [1530-1780] but the Netherlands and England were unique in having successful political revolutions which led to greater commercial influence over governments." It was this commercial influence that enabled British and Dutch growth.

Additional empirical evidence that "capitalist" institutions are essential for the exploitation of growth opportunities is presented in Acemoglu, Johnson and Robinson (2002). We showed that societies with good institutions were the ones to take advantage of the opportunity to industrialize in the nineteenth century, while countries with institutions that did not constrain rulers and elites failed to industrialize.

\subsubsection{Capitalist institutions are typically not welcome by the whole society}

Although capitalist institutions increase total output and economic growth, they often harm the economic interests of the monarchy, landed interests and other established groups allied with the monarchy. In particular, limitations on the taxation power of the state reduce the rents of the Crown and other groups within the nobility. Similarly, the 
weakening of feudal labor relations and the migration of labor from rural to urban areas typically hurt the economic interests of the landed aristocracy (unless they can somehow successfully transition into commercial agriculture or other commercial businesses). Moreover, with the rise of the bourgeoisie to political power, many of the policies that protect the economic interests of landed groups are discontinued (the repeal of the Corn Laws in 1846 in Britain is a salient example of this).

Despite the fact that capitalist institutions increase total surplus in the society, it is often impossible for the emerging commercial and industrial interests to compensate the monarchy and other established groups that are being harmed by the resulting economic and social changes (see, e.g., Acemoglu and Robinson, 2002b). The main reason for this is that the groups that will gain from institutional change cannot commit to compensate the losers. More specifically, institutions curtailing the power of the monarchy not only provide secure property rights to the commercial and industrial interests, but also reduce the rents of the monarchy and groups allied with it. In addition, as the bourgeoisie gains economic power, it will also gain political power. Both factors imply that after the development of capitalist institutions, there will be limited redistribution away from the winners, the bourgeoisie, to compensate the losers, the Crown and various segments of the landed interests.

Because the monarchy and the landed aristocracy expect to lose from the emergence of capitalist institutions, they will often oppose it. The classic account of the rise of capitalist institutions in England by Barrington Moore expresses this as follows (1966, p. 21): "Both the capitalist principle and that of parliamentary democracy are directly antithetical to the ones they superseded and in large measure overcame during the Civil War..." Moore goes on to argue that the emergence of capitalist institutions in England happened against the wishes of the landed interests (1966, chapter 1). This account also receives support from other historians. For example, Hill (1961) writes of the 17thcentury landed aristocracy: "in general the official attitude to industrial advance was hostile, or at best indifferent. It was suspicious of social change and social mobility, of the rapid enrichment of capitalists, afraid of the fluctuations of the market and of unemployment, of vagabondage, and social unrest ....the Elizabethan Codes aimed at stabilizing the existing class structure, the location of industry and the flow of labor supply by granting privileges and by putting hindrances in the way of mobility and the freedom of contract." 


\subsubsection{Institutions favored by powerful groups are more likely to prevail}

History is full of examples where powerful groups are able to impose their institutional choices on the rest of the society. ${ }^{27}$ In the context of the emergence of capitalist institutions, it is clear that the nascent bourgeoisie wants these institutions, while the monarchy and groups allied with it typically oppose them. As a result, there will be frequent conflicts over the control of political power and the state, and on how to reform institutions. In his history of Europe in the 18th century, Rude describes the situation as follows (1972, p. 175): "It was inevitable ... that tensions should arise and demands be voiced for an extension of authority by one or other of the principal contenders and for a share in government by those who had been hitherto excluded".

Therefore, the evolution of institutions typically reflects the relative power of various groups in the society: when the bourgeoisie becomes more powerful, the emergence of capitalist institutions becomes more likely. Again Barrington Moore argues that: “...in England the chief carriers of what was eventually to be a modern and secular society were... men of commerce in both the countryside and the towns" (1966, p. 13). And capitalist institutions emerged because capitalist groups were powerful enough during certain periods. In North's words "control of the state was, for a brief period of time, in the hands of groups whose self-interest promoted the growth of market forms of resource allocation" (1981, p. 180). ${ }^{28}$

\footnotetext{
${ }^{27}$ The emergence of democratic institutions in Western Europe during the 19th century is a salient example. In most instances, democratization occurred when groups excluded from political power were strong and wanted to change the prevailing institutions so that they could share power in the future (see Acemoglu and Robinson, 2000a). Another example is the introduction of proportional representation into Western European countries which, Rokkan (1970) argued, was due to conservative parties attempting to undermine the electoral strength of socialists. A final interesting example is the Napoleon's imposition of the "Napoleonic" legal codes in France and the territories he occupied to increase his control of judges and the administration of justice.

${ }^{28} \mathrm{An}$ interesting question, which falls beyond the scope of our inquiry, is why the new groups that gained strength attempted to set up institutions restricting the power of the monarchy and securing broad-based property rights rather than replacing the monarchy with their own oligarchy or a regime that simply enforced their own rights. We conjecture that this may have been because the coalition against the monarchy had to be broad-based, including commercial farmers, overseas merchants and merchants involved in domestic trade. Given the heterogeneity of this coalition, limiting the expropriation powers of the monarchy may have been a lowest common denominator. Though plausible, this is only a conjecture, and future research on this question might reveal different underlying reasons for this outcome.
} 


\subsubsection{Atlantic trade strengthened the nascent bourgeoisie}

The political power of the nascent bourgeoisie reflected, to a large extent, its economic power. As the commercial interests became richer they could demand and obtain reforms. This was both because other groups in the society needed their economic cooperation, and also because their economic power often bought them military power, or at least the power to undertake social unrest and mount threats to the regime. Examples of the bourgeoisie using its economic power to disrupt the system - in fact, to disrupt it quite violently - include the English Civil War in the 1640's and the social unrest leading up to the 1832 Reform Act in England, the Dutch rebellion against the Spanish Empire beginning in 1572, and perhaps, the 1789 Revolution in France.

With the surge in Atlantic trade, the economic power of commercial and industrial interests grew considerably. Even though O'Brien's (1982) estimates imply that the contribution of profits from international trade to capital accumulation was modest, the size of these profits were very large - about 5.5 to 7.5 percent of GDP. Perhaps more significantly, these profits were concentrated in the hands of a relatively small section of the bourgeoisie.

Many historians also emphasize the role of merchants, and especially of merchants engaged in Atlantic trade, in the transformation of British and Dutch institutions (see Brenner, 1973, 1993, Stone, 1972, Pincus, 1998, 2002, on Britain; and Israel, 1989,1995, de Vries and van der Woude, Ch 11, on the Netherlands). ${ }^{29}$

In the next subsection, we provide more detailed historical evidence from the British and Dutch cases that Atlantic trade indeed strengthened the commercial bourgeoisie in these countries, and via this channel, played an important role in the emergence of capitalist institutions. We focus on Britain and the Netherlands, since according to our hypothesis, the beneficial institutional changes should take place in societies where new merchants are the main beneficiaries of the profits from trade, and not in relatively absolutist countries such as Spain and Portugal. ${ }^{30}$

\footnotetext{
${ }^{29}$ It is also useful to note at this point that we are not arguing that international trade will create a tendency towards better institutions. International trade may strengthen groups that favor the status quo, or non-capitalist institutions. Over the same period, trade with Western Europe may have strengthened the landed aristocracy in Eastern Europe, or even led to the emergence of highly absolutist and extractive institutions there, for example with the second serfdom (Brenner, 1977). Similarly, trade with Europe was almost undoubtedly important for the power of sugar planters in the Caribbean, who maintained highly extractive institutions based on slavery and forced labor (e.g., Williams, 1944).

${ }^{30}$ In this context, France can be viewed as an intermediate case. Early Atlantic activity enriched some merchant groups, in particular, the protestant Huguenots. The monarchy soon clashed with and
} 


\subsection{Atlantic Trade and the Bourgeoisie}

\subsubsection{The British case}

In the British case, the period under the rule of Charles I witnessed intense conflict between the Crown and other social groups on the extent of the powers of the monarchy, the security of private property, and the extent of royal monopoly in the trading activities. Charles I dissolved his third parliament in 1629 and attempted to rule without parliament, raising taxes in an unconstitutional way and using the Star Chamber to manipulate legal decisions in his favor. Charles's reign slowly disintegrated into the Civil War in 1642. The Civil War and the Glorious Revolution of 1688, where James II was deposed and replaced by William of Orange and a parliamentary regime, are seen as two milestones towards the emergence of British political institutions constraining the monarchy, though the emphasis placed on each varies from historian to historian. For example, North and Weingast (1989), following Macaulay (1849), and Trevelyan (1938), emphasize the importance of the Glorious Revolution. Yet the struggle for these institutions may be dated back to the reign of Elizabeth I, for example when the Commons obstructed the creation of monopolies and the sale of titles, and they were established initially by the Long Parliament in 1641 where Charles I made many critical concessions. After the Restoration of the monarchy in 1660, the parliament kept most of what it had won until the struggle with James II.

For our purposes, the relative importance of the Civil War and the Glorious Revolution in the development of capitalist institutions is secondary. What is important is that both of these major changes came as a result of political conflict between the monarchy and (new) bourgeois interests demanding protection for their property and commerce. ${ }^{31}$ Merchants who benefitted from Crown monopolies had complex positions,

defeated the Huguenots, first with the siege of La Rochelle by Louis XIII and then, the outlawing of the Protestant church by Louis XIV (see, e.g., Scoville, 1960, and Valone, 1994). The monarchy then kept much of overseas trading activity under its monopoly, especially under Colbert (see, e.g., Davis, 1973a, pp. 222-224, and Doyle, 1974, pp. 210-211). Nevertheless, certain strong French bourgeois elements developed, and arguably, forced institutional change before, during and after the French Revolution (see Lefebvre, 1947, and Doyle, 1988, for the debate on the origins of the French Revolution).

${ }^{31}$ Other prominent interpretations of the English Civil War have emphasized various factors apart from those we stress here. Russell (1990) emphasizes the idea that the Civil War was a plot by the traditional aristocracy to regain power it had lost under the Tudors. Many, for example, Morrill (1993), stress the role of religious differences in determining who supported which side, and more recent work by Manning (1996) stresses more general class conflict. Nevertheless, although there are doubtless elements of truth in most of these approaches, the general role of mercantile interests seems undeniable (see Richardson, 1998, for a balanced overview of the debate). 
but the evidence is relatively uncontroversial that the majority of the merchants, and even many of those with royal monopolies, supported the Parliament. ${ }^{32}$ For example, detailed analyses of the initial members of the Long Parliament in 1640 indeed show that a significant majority of merchants supported the Parliamentarian cause (see Keeler, 1954, and Brunton and Pennington, 1954). The latter authors, for example, document that of the 552 members of the Long Parliament, 50-70 were "members whose wealth came chiefly from trade" (Brunton and Pennington, 1954 p. 54). ${ }^{33}$ The members of the Commons from the City of London (the main center of mercantile activity), as well as many non-London commercial constituencies, such as Southampton, Newcastle and Liverpool, supported the Parliament against the King. ${ }^{34}$ Sacks (p. 230-247) shows that in Bristol trading, commercial and industrial interests outside of the local monopolistic trading company, the Merchant Adventures, were Parliamentarians. Brunton and Pennington (1954, p. 62) also note "in the country as a whole there was probably a prepondernace of Parliamentarian feeling among merchants." 35

More recent historical analyses tend to support the view that mercantile interests were Parliamentarian and they played an important role in the political conflict. Brenner (1993, p. 316) states: “The political activities and alignments of London's merchant community both expressed and helped determine the character of City and national conflict in the period leading up to the outbreak of Civil War. From November 1640, London politics and national politics became ever more inexorably intertwined, and overseas merchants played key roles at both levels." Moreover, the support of City of London for the Parliament was in fact critical because of the resources and manpower

\footnotetext{
${ }^{32}$ Pearl's seminal study (1961) argued that there were political divisions between groups such as the Merchant Adventurers who benefited from monopolies granted by the Crown and new merchants, who did not. Ashton $(1979,1996)$, on the other hand, argued that even merchants who enjoyed monopolies, tended to oppose the Crown by the Civil War. Ashton argues (1996, p. 3) "the majority of the City fathers, far from being the natural supporters of Stuart absolutism at the end of the period of Charles I's personal rule in the late 1630's, were as alienated from royal policies as were the vast majority of the political nation."

${ }^{33}$ This in itself shows the great social mobility of the age since in 1584 mercantile interests were practically unrepresented in the House of Commons (see Neale, 1949).

${ }^{34}$ See Brunton and Pennington (1954, especially p. 60). The two MP's for Bristol, Humphrey Hooke and Richard Long were Royalists, but this reflected the intra-merchant conflict emerging from the granting of monopoly trading rights (see Pearl, 1961, and Sacks, 1991).

${ }^{35}$ There are some other regularities about who sided with whom in the Civil War which are consistent with our thesis. Brunton and Pennington (1954, p. 178) note the existence of "the predominantly Royalist North and West and the predominantly Parliamentarian South and East." The South and East were the most prosperous, commercial and modern areas of the country. See Hughes (1998) for a general discussion of this issue and Broxap (1972) for the intra-Lancashire pattern.
} 
it made available. In his seminal book Stone (1972, p. 144) writes: “... other important merchant elements can now be identified, men interested especially in the American trades, in New England colonization, and in breaking the monopoly of the East India and Levant Companies. They were new men in new fields of entrepreneurial endeavor who chafed at the political and economic stranglehold of the older established monopolistic oligarchies. These men were important members of the group of radicals who seized control of London at a critical moment in 1641, and so swung the power and influence of the city decisively on the side of Parliament."

The economic policies after 1649 and the final triumph of the Parliament are consistent with the rising power of merchants. Most significant were the Navigation Acts of 1651 and 1660 which restricted trade in British colonies to British ships and merchants (see Farnell, 1964, Cooper, 1972, and Guaci, 2001). One immediate implication was that British merchants could capture the lucrative slave trade from the Dutch, since the Navigation Acts banned the Dutch from supplying slaves to the British West Indian colonies. Holmes (1993, p. 64) refers to the African slave trade as "manifestly a child of the Navigation Act, which illegalised the activities of the Dutch slavers who had hitherto supplied the labour needs of the British planters."

A similar argument which emphasizes the critical role of mercantile interests in the Glorious Revolution of 1688 has recently been developed by Pincus (1998, 2001, 2002). He notes that James II favored the East India Company and granted various monopoly privileges, alienating the merchant class. Thus, "no wonder the merchant community poured money into William of Orange's coffers in 1688." (Pincus, 2002, p. 32-33). He concludes (p. 34) "England's merchant community actively supported William's plan for invasion, and provided a key financial prop to the regime in the critical early months."

The Glorious Revolution led to a whole series of policies which initiated the financial revolution, particularly the founding of the Bank of England and, with the exception of the East India Company, the wholesale demise of monopoly charters (see Carruthers, 1996). Guaci (2001, p. 218), for example, describes this process of increasing free entry into trading activities as follows: "Parliament was used to attack monopolies, and the great onslaughts against the London overseas trading companies accounted for nearly a third of all petitions considered there. This colossal wave of anti-company sentiment demonstrated that Parlaiment, and not the Crown, was regarded as the national arbiter on commerce, and its enhanced post-Revolutionary authority was sought as a weapon to undermine the royal authority of the company charters." 


\subsubsection{The Dutch case}

Turning to the Dutch case, it would be a fair characterization to view the history of the Netherlands during the 16th and early 17th centuries as the history of the struggle between merchants, especially the wealthy and politically powerful Regents, and the Habsburg monarchy. While the monarchy tried to increase its tax revenues from the Netherlands, the merchants tried to minimize taxes and fought for security of property and for independence from Spain.

An early milestone was the granting of the Grand Privilege of 1477 which gave the States General of the Burgundian Netherlands the right to gather on their own initiative and curbed the right of the ruler to raise taxes. However, by 1493 Maximilian of Habsburg reversed the privileges. After 1552, war with France increased the Habsburgs' fiscal needs and led them to impose a large tax burden on Netherlands. In 1556 when Charles V abdicated in favor of his son Philip II, the Netherlands rejected his first set of fiscal demands, only grudgingly paying up in 1558 under their own terms.

Growing fiscal and religious resentment in 1572 led to a series of uprisings against the Habsburgs, mostly orchestrated by commercial interests (see Israel, 1995). De Vries and van der Woude (1997, p. 369) argue that "urban economic interests ultimately believed it advantageous to escape the Habsburg imperial framework". In the case of Amsterdam, de Vries and van der Woude (1997, p. 365) note: "the ruling faction instinctively chose the cautious path of loyalty to Catholicism and the Habsburg regime... Their opponents included most of the city's international merchants.....[I]n 1578 a new Amsterdam city council threw the city's lot in with the Prince of Orange... among the merchants returning from... exile were [those whose families] and several generations of their decendents would long dominate the city."

Not only did commercial interests wish to escape the Habsburg regime, but they were becoming rich enough to turn their wishes into action. Israel (1995, pp. 241242) describes this as follows: "From 1590, there was a dramatic improvement in the Republic's economic circumstances. Commerce and shipping expanded enormously, as did the towns. As a result, the financial power of the states rapidly grew, and it was possible to improve the army vastly, both qualitatively, and quantitatively, within a short space of time. The army increased from 20,000 men in 1588 to 32,000 by 1595, and its artillery, methods of transportation, and training were transformed" (see also Israel, 1989, Chapter 3). By 1629, the Dutch were able to field an army of 77,000 men, 
50\% larger than the Spanish army of Flanders (Israel, 1995, p. 507).

After the Dutch revolt, it was the wealthy, predominantly Protestant merchants, the Regents, that dominated the city and state politics. ${ }^{36}$ De Vries and van der Woude (1997, p. 587) in their analysis of the relationship between soico-economic position and political influence note the that the richest people consisted of those "6 to $8 \%$ of urban households with incomes in excess of 1,000 guilders per year. This was the grote burgerij from whom was drawn the political and commercial leadership of the country. Here we find, first and foremost, the merchants." 37 In fact, the Dutch Revolt also served to weaken the position of Dutch nobles in the two largest states, Zeeland and Holland. Again quoting de Vries and van der Woude (1997, pp. 507-508): "Many nobles ... were ... excluded from the political system when the new Republican order triumphed... Only the Prince of Orange remained as a qualified representative of the noble order, and three attempts by other nobles (in 1615, 1616 and 1651) to be restored to their ancient rights were torpedoed by the cities in Zeeland. These cities, indeed, were the great winners of this process."

Full independence for the Dutch Republic was not secure until the war against the Habsburgs was completed with the Peace of Westphalia in 1648. In this process, the role of merchants was central. Dutch bankers and trading companies financed the independence war and dictated policy. Adams (1994, p. 329) quotes Elias in arguing that "The leading edge of commercial expansion shifted to the colonial and rich trades, and the merchants engaged in colonial trades, proclaiming the need for the states to help merchants secure wider opportunities in the Indies, swept into power in Amsterdam in 1601". De Vries and van der Woude (1997, p. 366) note that it was "the traditional pillars of the maritime economy ... that supported and strengthened the young Republic in its hour of need."

\section{Atlantic Trade and Institutional Change}

We now attempt to substantiate our hypothesis further by providing empirical evidence on the link between the emergence of capitalist institutions and conflict between different

\footnotetext{
${ }^{36}$ The strength and interests of the Dutch merchants can also be seen in the following episode. Following Spain's offer to recognize Dutch independence if they withdrew from the East and the West Indies, the Dutch responded that "too many prominent personages in the Republic were involved in the East India Company for it to be disbanded" (Israel, 1995, p. 9).

${ }^{37}$ For example, de Vries and van der Woude (1997, p. 587) show how merchants dominated the governments of Leiden and Rotterdam.
} 
social groups, and on the role of Atlantic trade in institutional change.

\subsection{Measuring Institutions}

A prerequisite for this exercise is a measure of capitalist institutions. Ideally, we would like to measure the essential ingredients of our definition of capitalist (political and economic) institutions, which included both political and economic elements: the degree of constraints on the monarchy (or equivalently the degree of absolutism) and other established groups; the security of property rights for a broad cross-section of society; and the extent of free entry into lucrative businesses. Unfortunately, no such measure exists for the period that we are analyzing. So as a first step, we attempted to create a measure of political institutions for European countries between 1300 and 1850. We started with the definition of "constraint on the executive" from Gurr's Polity data set, which gives a score between 1 to 7 for every (independent) country starting in 1800 . This is a useful concept since it measures limitations on the arbitrary use of power by the executive (for the relevant time period, the monarchy), and is presumably correlated with the security of property rights of merchants and the control over the monopoly of overseas trade by the monarchy.

We follow the Polity IV coding handbook in using the following criteria for coding "constraint on the executive" (Marshall and Jaggers, 2000). A value of 1 means "there are no regular limitations on the executive's actions," 3 means "there are some real but limited restraints on the executive," 5 means "the executive has more effective authority than any accountability group, but is subject to substantial constraints by them," and 7 means "accountabilty groups have effective authority equal to or greater than the executive in most activity." Scores of 2, 4, and 6 are used for intermediate values.

The measure of constraint on the executive is not ideal for our purposes, however, since during European history a number of significant constraints on monarchs were imposed by the nobles, and did not necessarily serve to protect the rights of the bourgeoisie. For example, in much of the 1500-1750 period, Poland had a highly constrained executive. But there was relatively little protection for urban merchants-most of the rights rested with the nobility.

For this reason, we modified the definition of constraint on the executive to create an alternative measure, which we refer to as "protection for capital". The coding of this measure depends on the formal rights given to urban merchants, particularly their protection in the event of a dispute with the nobility or monarch. A code of 1 indicates 
that these merchants have no effective protection against arbitary confiscation by the ruler (e.g., as was the case in most absolutist regimes). A code of 3 indicates that there are some city charters that give some rights to merchants, for example to be tried in courts run by their peers. A code of 5 indicates that the merchants and the "middle classes" have effective parliamentary representation. A code of 7 indicates that the government is formed by and largely influenced or controlled by merchants and middle classes. Other codes indicate intermediate values. In practice, our view of the appropriate coding was based on our assessment of constraint on the executive, adjusted by available evidence on legal protections for merchants. We believe that the protection of capital is a better proxy for capitalist institutions, while the constraint on the executive measure makes comparison with Polity IV data set easier.

For 1800 and 1850, we use the Polity coding for constraint on the executive, where available. For earlier periods, we coded these measures ourselves, as well as asking an able research assistant to code them independently from the same sources (and without knowing our hypothesis). The main source for this exercise was Langer (1972), a classic historical encylopedia, written with a focus on constitutional events. We supplemented this work with the more recent edition by Stearns (2001). The Appendix gives our coding and describes the procedure in more detail. ${ }^{38}$ More generally, while there may be disagreement about the precise values used in particular years, the general level of constraint on the executive does not appear to be controversial. For example, the absolutist regimes of France and Spain clearly had much less constraint on the executive than did the Netherlands after independence or England after the Civil War. Details on our coding strategy and the full series and some reasonable alternatives are given in the Appendix. ${ }^{39}$

Other evidence, both on the the extent of absolutism and on the control of overseas trading activity by the monarchy, also supports our coding based on formal constraints. Davis (1973b, p. 210) contrasts the constraints on the monarchy in England with Spain and France, and writes: "the financial check held back the crown from costly expenditure

\footnotetext{
${ }^{38}$ We have also checked our results using the three codings of institutions in De Long and Shleifer (1993). While their measures of institutions are somewhat different, for example awarding a much "better" score to feudal systems than does coding based on the Polity criteria, the overall results using their codes are the same. Essentially, in their coding as in ours, republics have more protection for capital than absolutist regimes. This point is both critical to our empirical analysis and fairly uncontroversial.

${ }^{39}$ One of the major issues is how to code Ireland. For much of the period, Ireland was under British control, so one possibility would be to assign Ireland British institutions. An alternative would be to give them lower scores, since they were "a colony" of Britain. Our results are robust to both alternatives.
} 
in wartime; the vast and ruinous outpouring of treasure which Philip II or Louis XIV were able to continue over long periods was not matched by any English monarch until the responsibility for war became largely a parliamentary one after the Revolution of 1688." Elsewhere, he emphasizes the high degree of absolute control by the monarchy in Spain as follows: [in Castile] "the king ruled subject only to weak constitutional restraints. In the first decades of the sixteenth century the crown had reduced the pretensions of the Castilian nobility and towns, so that the representative body, the Cortes, could obstruct but not in the last resort prevent royal tax raising." (Davis, 1973a, p. 66). ${ }^{40}$

Historians also emphasize the differences in the organization of trade between Britain and Spain, in particular, the role played by monopoly companies, and how these differences determined who the main beneficiaries of the gains from overseas activities were. Davis shows that in Britain "most trade was carried on by individuals and small partnerships, and not by the Company of Merchant Adventurers, the Levant Company....or others of their kind" (Davis, 1973b, p. 41). At least by 1600 there was quite free entry into the the British merchant class (Lang, 1974). In contrast, in Spain and Portugal, overseas activities were monopolies tightly controlled by their monarchies. Cameron (1993, p. 127) describes the situation as follows: "The spice trade in the East Indies of the Portuguese Empire was a crown monopoly; the Portuguese navy doubled as a merchant fleet, and all spices had to be sold through the Casa da India (India House) in Lisbon ... no commerce existed between Portugal and the East except that organized and controlled by the state" (see also Boxer, 1985, and Hamilton, 1948). In Spain, similarly, colonial trade was a monopoly of the Crown of Castille, which they delegated to the Casa de Contratación (House of Trade) in Seville. This merchants guild was closely monitored by the government (Parry, 1966, Ch 2). ${ }^{41}$

\footnotetext{
${ }^{40}$ The modern literature, in particular, Thompson (1994) and Graves (2001), suggests that the extent of Spanish absolutism has been overemphasized by scholars such as North and Thomas (1973), and points out important differences between Castile, and other parts of Iberia such as Aragon and Catalonia. Nevertheless, it is certainly true that the Spanish Crown was able to create trade monopolies and raise taxes in ways that the Tudor and Stuart monarchies were unable to do and much evidence still supports the claim of North and Thomas (1973, p. 128) that: "The price of domestic peace and secure property rights [...brought by Ferdinand and Isabella]... was loss of liberty in the Cortes, the grant to the Crown of the sole power to set taxes".

${ }^{41}$ Why were Spain and Portugal more absolutist than Britain and the Netherlands? These questions are beyond the scope of our study, but there are some obvious conjectures. Pre-1500 developments in Britain, including the balance of power between the Crown and the nobles, for example as encapsulated by the Magna Carta of 1215, placed a number of restrictions on the monarchy, even on those with absolutist tendencies such as Henry VII or Henry VIII. In the context of the Netherlands, it has been argued that the political system was more "participatory" because these areas were faced with collective action problems due to their low elevation above sea level, which necessitated a high degree of
} 
Finally, we also looked at whether each major institutional change happened amidst significant social conflict. Most of the major changes towards capitalist institutions in Europe between 1300 and 1850 were driven by significant social and political conflict: the Dutch revolt, the Civil War in England, and the French Revolution. Through 1800, almost all institutional changes happened amidst significant conflict, and according to our interpretation, because of significant conflict. In other words, this reading of the historical evidence is consistent with the view that capitalist institutions were not given by the monarchy and landed aristocracy, they were demanded and taken by new segments of the bourgeoisie.

\subsection{Explaining European Institutional Changes}

Figure 8 plots average institutions, using the above measure of constraint on executive and with population as weights as before, in Atlantic traders and non-Atlantic traders. It depicts much more marked improvement in the institutions of Atlantic traders. Table 9 shows the same pattern using regression analysis (see Appendix Table 5 for results with the alternative coding of constraint on executive). It estimates models of the following form

$$
I_{j t}=d_{t}+\delta_{j}+\sum_{t \geq 1600} \alpha_{t} \cdot W E_{j} \cdot d_{t}+\sum_{t \geq 1500} \beta_{t} \cdot P A T_{j} \cdot d_{t}+X_{j t}^{\prime} \cdot \gamma+\varepsilon_{j t},
$$

where $I_{j t}$ is our measure of institutions in country $j$ at time $t$ (constraint on the executive in the first part and protection for capital in the second part) and as before, $W E_{j}$ is a dummy indicating whether the country is in Western Europe, the $d_{t}$ 's denote year effects and the $\delta_{j}$ 's denote country effects, $X_{j t}$ is a vector of other covariates, and $\varepsilon_{j t}$ is a disturbance term. This equation is identical to (1), except for the dependent variable. $P A T_{j}$ is either a dummy for Atlantic trader or the Atlantic coastline-to-area ratio. The interactions between $P A T_{j}$ and the post-1600 dates capture the importance of Atlantic trade for institutional changes (and the 1500 interaction again allows a specification test).

cooperation in towns and some amount of urban autonomy. In addition, the quality of the land and soil was relatively poor, and this appears to have discouraged the formation of strong feudalistic structures (see de Vries and van der Woude, 1997, see also Anderson, 1974b, and Ertman, 1997).

In the Spanish case, the war against the Moors and the struggle over law and order until late in the 15th century appear to have strengthened the central state. Moreover, there was a crucial civil war between Charles V and Nobles at the beginning of the 16th century. In 1538 Charles expelled the Nobles from the parliament (the Cortes) leaving only the representatives of the towns (Graves, 2001, p. 72-73). This victory of Charles V strengthened the Crown and reduced the power of the Cortes further. 
Significant estimates of $\alpha_{t}$ 's imply that there was a differential evolution of institutions in Western Europe after 1500. This can be seen in column 1. When we include the interaction terms with Atlantic trade, i.e., the $P A T_{j} \cdot d_{t}$ 's terms, this leads to significant estimates of $\beta_{t}$ 's, indicating that there is a close connection between Atlantic trade and the development of capitalist institutions. For example, the estimate of $\beta_{1850}=2.96$ in column 2 indicates that the average score of the constraint on the executive increased by 2.96 points more among Atlantic traders between 1300-1400 and 1850 (for a sense of the scale, note that the improvement in British institutions between 1600 and 1750 is 3). Again, notably, $\beta_{1500}$ is insignificant (in fact, here it is negative), showing that there were no differential pre-existing trends between Atlantic traders and other Western European nations.

The inclusion of interaction terms with Atlantic trade weakens the differential improvement in West European institutions relative to East European institutions, and there is no longer a statistically significant differential improvement institutions in West Europe in column 2. However, the differential West European effects continue to be significant in the structured specification of column 3, and when we use the coastlineto-area ratio measure in column 8 .

Other columns in these tables use the same controls and time interactions as in Table 4. Although the F-statistics show that many of these time interactions are significant, being Protestant, having more wars, having a Roman heritage or being further north do not appear to have led to greater institutional change after 1500 (for example, institutions in Protestant countries improved more rapidly until 1750, and significantly slower thereafter). ${ }^{42}$ Overall, these results suggest that there were greater strides towards better institutions in nations engaged in Atlantic trade, or those with a greater potential to engage in Atlantic trade, more or less around the time of the surge in Atlantic trade.

\section{The Role of Initial Institutions}

As emphasized in Section 3, our hypothesis also suggests that Atlantic trade should have induced more rapid institutional and economic development when new merchants,

\footnotetext{
${ }^{42}$ In our base estimates, we measure institutions in Northern Italy and we ascribe "Italian" GDP per capita and urbanization to Northern Italy. Adding Southern Italy would strengthen our results. This region was relatively rich in 1500 (though slightly less so than Northern Italy), with somewhat weaker constraint on the executive. Over the next 300 years it did not participate actively in Atlantic trade, stagnated in economic terms and did not improve its institutions, so adding this country to our data would be equivalent to adding another country like Austria - it would increase our ability to distinguish between Atlantic and non-Atlantic Western Europe.
} 
the groups in favor of institutional change, benefited substantially from Atlantic trade. However, as discussed above, the Spanish, Portuguese and to some extent French monarchies were quite powerful at the turn of the 15th century and during the early stages of the 16th century, and managed to tightly control overseas activities, granting monopolies to groups loyal to themselves, and new groups benefited relatively little from the opportunities offered by Atlantic trade (see, e.g., Davis, 1973a, Cameron, 1993, Parry, 1966, Davis, 1973a, Doyle, 1974). As a result, in all three countries, the monarchy and groups allied with the monarchy became the major beneficiaries of the profits from trade and plunder from the New World and Asia via the Atlantic. So our hypothesis implies a weaker tendency towards beneficial institutional change in countries where institutions placed little checks on the monarchy and allowed the monarchy to control the monopoly of trade. Armed with a quantitative measure of institutions, we now turn to investigating this aspect of our hypothesis.

\subsection{ECONOMETRIC EVIDENCE}

We would like to establish that it was predominantly societies with less absolutist initial institutions and those with relatively free entry into trading activities that took advantage of the opportunities offered by Atlantic trade. Since we have no quantitative measures of the organization of trade (the degree of monarchy-controlled monopoly in overseas trade), we are going to proxy both of these characteristics with our constraint on the executive variable. This is reasonable since sales of trading privileges were one of the major fiscal tools of relatively absolutist monarchies (see North, 1981). Therefore, we will look for differential responses of societies with different scores of initial constraint on executive to the opportunity to engage in Atlantic trade and colonialism.

We will also take this opportunity to test against a related hypothesis which is nonetheless quite different from ours: this alternative hypothesis is that post-1500 developments simply reflect divergence between societies that had very different institutions at the turn of the 15th century (see North and Thomas, 1973). This differs from our hypothesis which emphasizes the interaction between initial institutions and Atlantic trade.

To investigate these ideas, we estimate models of the following form:

$u_{j t}=d_{t}+\delta_{j}+\sum_{t \geq 1600} \alpha_{t} \cdot W E_{j} \cdot d_{t}+\beta \cdot \ln A T_{t} \cdot P A T_{j}+\sum_{t \geq 1500} \gamma_{t} \cdot I_{j, 1415} \cdot d_{t}+\eta \cdot \ln A T_{t} \cdot P A T_{j} \cdot I_{j, 1415}+\varepsilon_{j t}$ 
where, as before, $u_{j t}$ is the urbanization rate, $\ln A T_{t}$ is our measure of Atlantic trade, $P A T_{j}$ is again either a dummy for Atlantic trader or the Atlantic coastline-to-area ratio, and $I_{j, 1415}$ is country $j$ 's "initial institutions," the average of its institutions (constraint on the executive) in 1400 and 1500 . We choose the average of these two dates to capture the long-term institutional differences in the pre-1500 period. The $\gamma_{t} \cdot I_{j, 1415} \cdot d_{t}$ terms allow any differential economic trends simply related to differences in initial institutions, which would apply with no access to the Atlantic. Significant coefficients on these interaction terms would imply that at least part of the post-1500 developments in Europe reflect divergent paths taken by countries with different initial institutions, independent of the effects of Atlantic trade. The table reports the p-value from a joint significance test for all of these interaction terms. The $\ln A T_{t} \cdot P A T_{j}$ term, on the other hand, measures the effect of Atlantic trade for a given level of institutions. In the table, this term is evaluated at the lowest score of institutions, i.e., for $I_{j, 1415}=1$, so the coefficient on this term measures the contribution of Atlantic trade and access to the Atlantic to the growth of a society with the worst possible initial institutions.

The variable $\ln A T_{t} \cdot P A T_{j} \cdot I_{j, 1415}$ tests the hypothesis of interest. A significant coefficient $\eta$ implies that there were divergent paths taken by countries with different initial institutions, but this divergence relates significantly to whether they took advantage of the opportunities presented by Atlantic trade.

We report the results in Tables 10A and 10B, where the first table uses the definition of Atlantic trader for $P A T_{j}$, while the second uses the coastline-to-area ratio measure. Panel A in both tables presents estimates from equation (9), while Panel B presents estimates from a similar equation with log income per capita as the dependent variable and Panel $\mathrm{C}$ shows regressions with institutions as the left-hand side variables, to document the role of the interaction between initial institutions and Atlantic trade for the development of capitalist institutions. To save space, we only report results using the constraint on the executive measure of institutions. Results with the protection for capital are similar.

The results in all three panels are similar. The interaction between the aggregate measure of Atlantic trade and potential for Atlantic trade, $\ln A T_{t} \cdot P A T_{j}$, is generally significant by itself, and also when entered against the $\gamma_{t} \cdot I_{j, 1415} \cdot d_{t}$ terms. This shows that the ability to take advantage of Atlantic trade was of major importance for post1500 developments. When we add the triple interaction $\ln A T_{t} \cdot P A T_{j} \cdot I_{j, 1415}$, this term 
is typically the only significant term. ${ }^{43}$ The coefficients on this triple interaction term implies that urbanization in an Atlantic trader with constraint on the executive equal to 3, like the Netherlands, grew by 15.7 percentage points more than urbanization in an Atlantic trader country with the worst initial institutions, $1(0.021 \times 2 \times 3.74 \approx 0.157)$.

The results in Tables 10A and 10B imply that the patterns reported so far are explained almost exclusively by societies with initial institutions constraining rulers taking advantage of the opportunities presented by Atlantic trade. In some sense, this is not surprising given the historical patterns. The "winners" of pre-modern Europe were Britain and the Netherlands, the two countries that started with relatively good initial institutions. Although Spain and Portugal took advantage of the resources transferred from the New World during the 16th century, they neither developed capitalist institutions to support economic growth nor experienced sustained economic development. This evidence, as well as our historical reading discussed below, suggest that these differential patterns are closely related to the fact that they started around 1500 with strong absolutist regimes that controlled overseas activity and became the main beneficiaries of the gains from trade and plunder. Italy, or more accurately the Italian city-states, which started with relatively non-absolutist institutions around 1500, did not experience further economic development either. The evidence in Table 10A and 10B explains these patterns by the fact that Spain and Portugal started the era of pre-modern economic development with relatively absolutist institutions and monarchy-controlled organization of trade, while Italy did not have as easy access to the Atlantic as Britain and the Netherlands. Britain and the Netherlands were the winners because they had both relatively good institutions to start with and easy access to the Atlantic.

\subsection{Historical Perspective and Discussion}

The empirical results presented so far, especially those in Tables 10A and 10B, paint a picture in which societies with relatively good initial institutions circa 1500 and with easy access to the Atlantic developed rapidly in the centuries after 1500, and this development was in large part driven by commercial growth under relatively capitalist institutions. In

\footnotetext{
${ }^{43}$ With the interaction term between institutions and potential for Atlantic trade, $\ln A T_{t} \cdot P A T_{j} \cdot I_{j, 1415}$, is included, $\ln A T_{t} \cdot P A T_{j}$ has typically a negative, and sometimes significant, coefficient reinforcing the conclusion that nations with absolutist institutions did not benefit much, or even at all, from the opportunity to trade in the Atlantic. In addition, in three specifications in Table 10A and one in Table 10B, the initial institutions and post-1600 interactions are jointly significant, but the coefficients (not shown in the tables) are negative in Table 10A and only initially positive in Table 10B.
} 
the meantime, societies with highly absolutist institutions and those without easy access to the Atlantic failed to develop such capitalist institutions and did not experience similar economic development. Is the historical evidence also consistent with this hypothesis?

Our reading of the relevant history suggests that the answer is yes. Consistent with our interpretation here, the initial differences in the organization of trade discussed in Section 4.1 had a major effect on who benefited from trade, and the subsequent political development of the countries. While Britain progressed down the path leading to capitalist institutions, the state became more absolutist in Spain and Portugal.

These different institutional paths of Britain and Spain appear to have led to divergent economic outcomes. Secure property rights in Britain encouraged commerce, industry and production for the market, while the Spanish economy crumbled under high taxes and insecure property rights. For example, the most common argument in the literature is that the Spanish decline resulted from a succession of kings bankrupting the country with high taxes and irresponsible fiscal policy (e.g., Kamen, 1965, and Kennedy, 1987). The classic work of Earl Hamilton (1938, p. 175) also develops the same argument. He writes: "The unbearable burden of taxation at the end of the sixteenth century and throughout the seventeenth was an important factor in the decline of Spain."

What about Italy? Italian urbanization grew between 1500 and 1600, but largely stagnated between 1600 and 1850, and according to Maddison (2001), Italian GDP was approximately stagnant between 1500 and 1820. Our hypothesis suggests that Italy did not develop as rapidly as Britain and the Netherlands because Italian city-states did not take part in Atlantic trade and colonialism. This most likely reflects lack of easy access to the Atlantic. Although to sail from Venice or Genoa to the Atlantic was not much harder than to sail from London or Amsterdam, it involved passage through the Straits of Gibraltar, which is 36 miles long and narrows down to 8 miles in width between Point Marroqui in Spain and Point Cires in Morocco, making such a passage difficult and dangerous when the Straits are controlled by the a rival strong naval power. The Straits were controlled first by the Spaniards and then subsequently by the British. Given the fact that the 16th and 17th centuries are predominantly characterized by incessant wars between Britain, the Netherlands, Spain, Portugal and France for the control of the Atlantic, this situation must have made it highly impractical for the Venetians and the Genoese to venture into the Atlantic relative to the ease with which the British or Dutch 
could engage in trading and pirating activities in the Atlantic. ${ }^{44}$

As a result, Italian city-states failed to benefit both from the direct and indirect effects of Atlantic trade, and in fact, part of the growth of Atlantic trade was replacing Italian Mediterranean trade, creating a negative impact on Italy. In the words of Cipolla (1970, p. 210) "the development of Atlantic trade routes progressively and irreversibly eliminated the Italians from the international trade in spices and tropical products". ${ }^{45}$ He also estimates that the value of goods imported and exported from Genoa in 1700 was $1 / 3$ of what it had been in 1600 (p. 199), and states that "the economic prosperity of Italy was fundamentally dependent on massive exports of manufactured articles (above all textiles), and on a huge volume of invisible exports such as banking and shipping services. The entire economic structure of the country depended on being able to sell abroad a large proportion of the goods it manufactured and of the services it could provide" (p. 202). In addition, during this period, the guilds may have started playing a negative role and Italian states pursued many growth-stifling policies, in particular imposing high rates of taxes. For example, Cipolla (1952, p. 207) writes: "The pressure of taxation in Italian states seems to have been too high, and badly conceived." This is somewhat similar to high taxes in Spain and Portugal stifling growth. ${ }^{46}$ Overall, therefore, it appears that Italian city-states stagnated for a combination of reasons, most importantly, because of the lack of access to the growth opportunities in the Atlantic, because they lost a large part of their export markets, and also because of a range of

\footnotetext{
${ }^{44}$ This is not to deny that other factors, for example existing Venetian and Genovese investments in Mediterranean trade, may have reduced Italian interest in the Atlantic, either through a social opportunity cost argument, or reminiscent of Olson (1982), because of existing vested interests who did not want a switch from the Mediterranean to other trading routes. Nevertheless, it seems clear that Italian city-states did not have easy access to the Atlantic at the turn of the 15th century.

${ }^{45}$ Lane (1940) shows evidence that the Mediterranean Spice Trade fell after 1500, but then recovered through 1600. That Venice and other parts of Italy experienced a declining share of Asian trade after that date is not controversial.

${ }^{46}$ Interestingly, Italian institutions not only failed to improve after the 15th century, but they may have actually deteriorated. This might reflect fluctuations due to idiosyncratic factors, or the fact that Italian merchants became weaker as they lost their export markets. It also possible that Italian institutions in 1500 were not as good as our numbers and most historians suggest, because they were highly oligarchic, giving the control of the states to established groups. (Or perhaps, quasi-capitalist institutions require new groups to gain economic power and prevent established groups from becoming too entrenched, which did not happen in Italian city-states in the post-1500 era). Currently, we cannot distinguish between these various views. However, what seems clear is that there were important political failures in Italian city-states. For example, Cipolla (1970) and Braudel (1992) suggest that the guilds stopped innovation in Italy, in particular they forbade the production of exactly the type of lower quality goods that were taking their markets. In contrast, Rapp (1976) argues that the failure did not originate in the guilds, but in the state. He documents that the guilds attempted to reform, but this was prevented by the state.
} 
policies stifling growth.

\section{Conclusion}

This paper documented a distinctive and interesting pattern in the process of European growth: during the critical period of European development, between 1500 and 1850, the growth of Atlantic nations and Atlantic ports accounts for most of the differential growth of Western Europe relative to other regions. In other words, the Rise of Europe between 1500 and 1850 was largely the rise of nations engaged in Atlantic trade and colonialism, and the rise of Atlantic ports. This fact has important consequences for theories of European growth. In particular, it appears that successful theories must give a prominent role to "Atlantic trade", and deemphasize the continuation of pre-1500 trends and permanent European characteristics, such as religion, Roman heritage or European culture. Instead, the interaction between these factors and the opportunity to trade in the Atlantic appears to have been crucial for the Rise of Europe.

We suggested that Atlantic trade contributed to European growth through an indirect institutional channel as well as its more obvious direct effects. Our hypothesis is that Atlantic trade generated large profits for a segment of the bourgeoisie in Western Europe, and this group could demand, obtain and sustain significant institutional reforms protecting their property rights. With their newly gained property rights, the bourgeoisie of Western European nations invested more, traded more and spurred economic growth. Our reading of European history is consistent with this interpretation, and we provided empirical evidence to further support this point of view.

The theory of European growth that emerges from this paper is quite different from many existing views. While it emphasizes the importance of property rights and institutions as in the work by North (1981), North and Thomas (1973) and De Long and Shleifer (1993), it sees the roots of these institutions not in Roman heritage or pre1500 developments, but in the strengthening of the bourgeoisie, especially new merchant groups, in the post-1500 period, most likely as a result of the profits from Atlantic trade and colonialism.

Our analysis stopped before West European industrialization, focusing instead on the economic and political developments between the 16th and 19th centuries. This period of the "First Great Divergence" likely laid the seeds of the Industrial Revolution and European industrialization as well as of modern capitalism. We did not try to analyze why some successful Atlantic nations, like the Dutch, did not industrialize, while Britain 
and non-Atlantic nations such as Germany did. We suspect that the answer is related to inter-state competition and "defensive modernization" responses of certain European nations, but this is a topic for another paper (Acemoglu, Johnson and Robinson, in progress).

At this point, we also must stress that the process of early modern European growth is undoubtedly multi-faceted. Any account of the history of a large and heterogeneous continent in terms of a few factors will be at best simplistic and at worst misleading. We are aware that many important aspects of the social and economic development of Western Europe are left out. It is nonetheless our hope that these hypotheses are plausible and will encourage high quality research on these topics. 


\section{REFERENCES}

Acemoglu, Daron, Simon Johnson and James A. Robinson (2001) "The Colonial Origins of Comparative Development: An Empirical Investigation," American Economic Review, December, Volume 91, Number 5, 1369-1401.

Acemoglu, Daron, Simon Johnson and James A. Robinson (2002) "Reversal of Fortune: Geography and Institutions in the Making of ther Modern World Income Distribution," forthcoming Quarterly Journal of Economics.

Acemoglu, Daron, Simon Johnson and James A. Robinson (in progress) "Inter-State Competition, Defensive Modernization and Industrialization in Europe" in progress.

Acemoglu, Daron and James A. Robinson (2000a) "Why Did the West Extend the Franchise? Democracy, Inequality and Growth in Historical Perspective," Quarterly Journal of Economics, 115, 1167-1199.

Acemoglu, Daron and James A. Robinson (2000b) "Political Losers as a Barrier to Economic Development," American Economic Review, 90, 126-130.

Acemoglu, Daron and James A. Robinson (2002) "Economic Backwardness in Political Perspective," NBER Working Paper \#8831.

Adams, Julia (1996) "Trading States, Trading Places: The Role of Patrimonialism in Early Modern Dutch Development," Comparative Studies in Society and History, 35, 319-355.

Allen Robert C. (1998) "The Great Divergence: Wages and Prices in Europe from the Middle Ages to the First World War," Discussion Paper 98-12, Department of Economics, University of British Columbia, August.

Anderson, Perry (1974a) Passages from Antiquity to Feudalism, London; NLB Press.

Anderson, Perry (1974b) Lineages of the Absolutist State, London; NLB Press.

Ashton, Robert (1979) The City and the Court, New York; Cambridge University Press.

Ashton, Robert (1996) "Insurgency, Counter-Insurgency and Inaction: Three Phases in the Role of the City in the Great Rebellion," in Stephen Porter ed. London and the Civil War, New Tork; St. Martin's Press.

Bairoch, Paul (1988) Cities and Economic Development: From the Dawn of History to the Present, University of Chicago Press, Chicago. 
Bairoch, Paul (1995) Economics and World History: Myths and Paradoxes, University of Chicago Press, Chicago.

Bairoch, Paul, Jean Batou and Pierre Chèvre (1988) La Population des villes Europeenees de 800 a 1850: Banque de Données et Analyse Sommaire des Résultats, Centre d'histoire économique Internationale de l'Uni. de Genève, Libraire Droz, Geneva.

Blaut, James M. (1993) The Colonizer's Model of the World: Geographical Diffusionism and Eurocentric History, New York; Guilford Press.

Boxer, Charles R. (1985) Portuguese Conquest and Commerce in Southern Asia, 1500-1750, London, Variorum Reprints.

Broxap, Ernest (1972) The Great Civil War in Lancashire 1641-1651, Manchester; University of Manchester Press.

Braudel, Fernand (1992) Civilization and Capitalism 15th-18th Century; Volume III The Perspective of the World, Berkeley; University of California Press.

Brenner, Robert (1973) "The Civial War Politics of London's Merchant Community, Past and Present, 58, 53-107.

Brenner, Robert (1977) "Agrarian Class Structure and Economic Development in Preindustrial Europe" Past and Present, No. 70, February.

Brenner, Robert (1993) Merchants and Revolution: Commercial Change, Political Conflict, and London's Overseas Traders, 1550-1653, Princeton; Princeton University Press.

Brunton, Douglas and D.H. Pennington (1954) Members of the Long Parliament, London; Allen and Unwin.

Butel, Paul (1997) Histoire de l'Atlantique, Perrin, Paris.

Cameron, Rondo (1993) A Concise Economic History of the World, New York; Oxford University Press.

Carlos, Ann, Yongmin Chen, and Ron Smith (2002), "Purchasing Strategies: The Case of the Royal African Company 1672-1699," unpublished manuscript, University of Colorado and Birkbeck College, September.

Carruthers, Bruce G. (1996) City of Capital: Politics and Markets in the English Financial Revolution, Princeton; Princeton University Press.

Chandler, Tertius (1987) Four Thousand Years of Urban Growth: An Historical Census, St. David's University Press, Lewiston, N.Y.

Ciccone, Antonio and Matsuyama, Kiminori (1999) "Efficiency and Equilibrium with Dynamic Increasing Aggregate Returns Due to Demand Complementarities" 
Econometrica vol 67, n3, 499-525.

Cipolla, Carlo M. (1952) "The Decline of Italy: The Case of a Fully Matured Economy," Economic History Review, 2nd ser., 5, 178-187.

Cipolla, Carlo M. (1965) Guns, Sails, and Empires: Technological Innovation and the Early Phases of European Expansion, 1400-1700, Minerva Press, location unspecified.

Cipolla, Carlo M. (1970) "The Economic Decline of Italy," in Carlo M. Cipolla ed. The Economic Decline of Empires, New York; Barnes and Noble.

Cipolla, Carlo M. (1981) Before the Industrial Revolution: European Society and Economy, 1000-1700, New York; W.W. Norton \& Co.

Cooper, J.P. (1972) "Social and Economic Policies under the Commonwealth," in G.E. Aylmer ed. The Interregnum: The Quest for Settlement 1646-1660, London; Macmillan.

Curtin, Philip (1984) Cross-Cultural Trade in World History, Cambridge.

Davis, Ralph (1956) "Merchant Shipping the Economy of the Late Seventeenth Century," The Economic History Review, New Series, Volume 9, Issue 1, 59-73.

Davis, Ralph (1962) The Rise of the English Shipping Industry in the Seventeenth and Eighteenth Centuries, Macmillan, London.

Davis, Ralph (1973a) The Rise of the Atlantic Economies, Ithaca; Cornell University Press.

Davis, Ralph (1973b) English Overseas Trade 1500-1700, Macmillan; London.

De Long, J. Bradford and Andrei Shleifer (1993) "Princes and Merchants: European City Growth before the Industrial Revolution, Journal of Law and Economics, 36, October, 671-702.

de Vries, Jan (1976) The Economy of Europe in an Age of Crisis, 1600-1750, Cambridge University Press, Cambridge.

de Vries, Jan (1984) European Urbanization, 1500-1800, Harvard University Press, Cambridge, Massachusetts.

de Vries, Jan (2001) "Connecting Europe and Asia: A Quantitative Analysis of the Cape Route Trade, 1497-1795," forthcoming in Dennis Flynn, Arturo Giraldez, and Richard von Glahn, editors, Monetary History in Global Perspective, London, Ashgate Publishers.

de Vries, Jan and Ad van der Woude (1997) The First Modern Economy: Success, Failure, and Perseverance of the Dutch Economy, 1500-1815, New York; Cam- 
bridge University Press.

Diamond, Jared M. (1997) Guns, Germs and Steel: The Fate of Human Societies, W.W. Norton \& Co., New York NY.

DK Publishing (1997) World Atlas, New York and London.

Dobb, Maurice H. (1946) Studies in the Development of Capitalism, London; Routledge \& Kegan Paul.

Doyle, William (1974) The Parlement of Bordeaux and the End of the Old Regime, 1771-1790, London: Ernest Benn.

Doyle, William (1988) Origins of the French Revolution, Oxford: Oxford University Press.

Eltis, David and Stanley L. Engerman (2000) "The Importance of Slavery and the Slave Trade to Industrializing Britian," Journal of Economic History, 60, 123-144.

Eltis, David, Stephen D. Behrendt, David Richardson, and Herbert S. Klein (1999). "The Trans-Atlantic Slave Trade: A Database on CD-Rom," compiled at the W.E.B. Du Bois Institute at Harvard, Cambridge University Press.

Engels, Freidrich (1892) [1945] Socialism: Utopian and Scientific, New York; International Publishers.

Engerman, Stanley L. (1972) "The Slave Trade and British Capital Fomration in the Eighteenth Century: A Comment on the Williams Thesis," Business History Review, 46, 430-443.

Engerman, Stanley L. and O'Brien, Patrick K. (1991) "Export and the growth of the British economy from the Glorious Revolution to the Peace of Amiens", in Solow, Barbara L. ed. Slavery and the Rise of the Atlantic System, Cambridge University Press, Cambridge.

Ertman, Thomas (1997) Birth of the Leviathan: Building States and Regimes in Medieval and Early Modern Europe, New York; Cambridge University Press.

Farnell, J.E. (1964) The Navigation Act of 1651, the First Dutch War, and the London Merchant Community, Economic History Review, New Series, 16, 439-545.

Frank, Andre Gunder (1978) Dependent Accumulation and Underdevelopment, Macmillan, London.

Galor, Oded and Andrew Mountford (2002) "Why Are a Third of People Indian and Chinese? Trade, Industrialization and Demographic Transition" Brown University mimeo. 
Gardiner, Robert (2000) Cogs, Caravels and Galleons: The Sailing Ship 10001650, Chartwell Books, Edison, New Jersey.

Graves, Michael A.R. (2001) The Parliaments of Early Modern Europe, New York; Longman.

Guaci, Perry (2001) The Politics of Trade: The Overseas Merchant in State and Society, 1660-1720, New York; Oxford University Press.

Gurr, Ted Robert (1997) "Polity II: Political Structures and Regime Change, 1800-1986," Unpublished paper, University of Colorado, Boulder.

Hall, John A. (1985) Powers and Liberties: The Causes and Consequences of the Rise of the West, Oxford; Blackwell.

Hamilton, Earl J. (1938) "Revisions in Economic History. VIII.- The Decline of Spain," Economic History Review, 8, 168-179.

Hamilton, Earl J. (1948) "The Role of Monopoly in the Overseas Expansion and Colonial Trade of Europe before 1800," American Economic Review, Volume 38, Issue 2, May, 33-53.

Hespanha, Antonio Manuel (1994), "Cities and the State in Portugal," in Charles Tilly and Wim P. Blockmans, editors, Cities and the Rise of States in Europe, A.D. 1000 to 1800, Westview Press, Boulder.

Hill, Christopher (1961) [1980] The Century of Revolution, 1603-1714, New York; W.W. Norton \& Co.

Hill, Christopher (1969) From Reformation to Industrial Revolution 1530-1780, Baltimore; Penguin Books.

Hintze, Otto (1970) [1906] "Military Organization and the Organization of the State." In Felix Gilbert (ed.). The Historical Essays of Otto Hintze, New York: Oxford University Press.

Hobsbawm, Eric J. (1999) Industry and Empire: From 1750 to the Present Day, New York; The New Press.

Holmes, Geoffery (1993) The Making of a Great Power: Late Stuart and early Georgian Britain, New York; Longman.

Hughes, Ann (1998) The Causes of the English Civial War, Second Edition, New York; St. Martin's Press.

Inikori, J.E. (1981) "Market Structure and the Profits of the British African Trade in the Late Eighteenth Century," The Journal of Economic History, Volume 41, Issue 4, December, 745-776. 
Inikori, J.E. (1983) "Market Structure and the Profits of the British African Trade in the Late Eighteenth Century: A Rejoinder," The Journal of Economic History, Volume 43, Issue 3, September, 723-728.

Inikori, J.E. (1985) "Market Structure and Profits: A Further Rejoinder," The Journal of Economic History, Volume 45, Issue 3, September, 708-711.

Israel, Jonathan I. (1989) Dutch Primacy in World Trade, 1585-1740, Oxford; The Clarendon Press.

Israel, Jonathan I. (1995) The Dutch Republic: Its Rise, Greatness and Fall 1477-1806, New York; Oxford University Press.

Jones, Eric L. (1981) The European Miracle: Environments, Economies, and Geopolitics in the History of Europe and Asia, Cambridge University Press, New York.

Kamen, Henry (1964) "The Decline of Castile: The Last Crisis," The Economic History Review, New Series, Volume 17, Issue 1 (1964), 63-76.

Kamen, Henry (1965) Confiscations in the Economy of the Spanish Inquisition, The Economic History Review, New Series, Volume 18, Issue 3, 511-525.

Keeler, Mary (1954) The Long Parliament, 1640-1641; A Biographical Study of its Members, Philadelphia; American Philosophical Society.

Kennedy, Paul M. (1987) The Rise and Fall of the Great Powers: Economic Change and Military Conflict from 1500 to 2000, Random House, New York.

Kohn, George Childs (1999) Dictionary of Wars, Revised Edition, Checkmark Books (an imprint of Facts on File, Inc.), New York.

Krusell, Per and Jose-Victor Rios-Rull (1996) "Vested Interests in a Theory of Stagnation and Growth," Review of Economic Studies, 63, 301-330.

Landes, David S. (1998) The Wealth and Poverty of Nations: Why Some Are So Rich and Some So Poor, W.W. Norton \& Co., New York.

Lane, Frederic Chapin (1934), Venetian Ships and Shipbuilding of the Renaissance, Johns Hopkins University Press, Baltimore.

Lane, Frederic Chapin (1940) "The Mediterranean Spice Trade: Further Evidence of its Revival in the Sixteenth Century," The American Historical Review, Volume 45, Issue 3, April, 581-590.

Lane, Frederic Chapin (1944), Andrea Barbarigo: Merchant of Venice, 14181449, The Johns Hopkins Press, Baltimore.

Lane, Frederic C. (1973) Venice: A Maritime Republic, Baltimore; Johns Hopkins University Press, Baltimore 
Lang, R. G. (1974) "Social Origins and Social Aspirations of Jacobean London Merchants," The Economic History Review, New Series, Volume 27, Issue 1, February, $28-47$.

Langer, William L. (1972) An Encylopedia of World History, Fifth Edition, Houghton Mifflin Company, Boston.

Lefebvre, G. (1947) The Coming of the French Revolution, Princeton: Princeton University Press.

Leunig, Tim (1998) "New Answers to Old Questions: Transport Costs and the Slow Adoption of Ring Spinning in Lancashire," University of Oxford, Discussion Papers in Economic and Social History, Number 22, February.

Lucas, Robert E. (1988), "On the Mechanics of Economic Development." Journal of Monetary Economics, 22, 3-42.

McEvedy, Colin and Richard Jones (1978) Atlas of World Population History, Facts on File, New York.

Maddison, Angus (2001) The World Economy: A Millenial Perspective, Development Centre of the Organization for Economic Cooperation and Development, OECD, Paris.

Mann, Michael (1986) and (1993) The Sources of Social Power (Two Volumes), Cambridge University Press, Cambridge.

Manning, Brian (1996) Aristocrats, Plebeians, and Revolution in England, 16401660, Pluto Press; New Haven.

Marshall, Monty G. and Keith Jaggers (2000) "Polity IV Project, Political Regime Characteristics and Transitions 1800-1999, Dataset Users Manual," Center for International Development and Conflict Management, University of Maryland.

Marx, Karl and Frederick Engels [1848] (1998) The Communist Manifesto, Mass Market Paperback, New York.

Mokyr, Joel (1990) The Lever of Riches: Technological Creativity and Economic Progress, Oxford University Press, New York and Oxford.

Moore, Barrington Jr. (1966) Social Origins of Dictatorship and Democracy: Lord and Peasant in the Making of the Modern World, Boston; Beacon Press.

Morgan, Kenneth (2000) Slavery, Atlantic Trade and the British Economy, 16601800, New York; Cambridge University Press.

Morrill, John S. (1993) The Nature of the English Revolution, Longman; New York. 
Neal, Larry (2000) "How It All Began: The Monetary and Financial Architecture of Europe during the first global capital markets, 1648 to 1815," Financial History Review, 7:2, 117-140.

Neale John E. (1949) The Elizabathen House of Commons, London; Jonathan Cape.

North, Douglass C. (1968) "Sources of Productivity in Ocean Shipping, 16001850," Journal of Political Economy, Volume 76, Issue 5, Sept.-Oct. 953-970.

North, Douglass C. (1981) Structure and Change in Economic History, New York; W.W. Norton \& Co.

North, Douglass C. (1990) Institutions, Institutional change, and Economic Performance, Cambridge University Press, New York.

North, Douglass C. and Robert P. Thomas (1973) The Rise of the Western World: A New Economic History, Cambridge University Press, Cambridge UK.

North, Douglass C. and Barry R. Weingast (1989) "Constitutions and Commitment: Evolution of Institutions Governing Public Choice in Seventeenth Century England, Journal of Economic History, 49, 803-832.

O'Brien, Patrick K. (1982) "European Economic Development: The Contirubution of the Periphery," Economic History Review, 2nd ser., 35, 1-18.

O'Brien, Patrick K., Trevor Griffiths, and Philip Hunt (1982) "Political Components of the Industrial Revolution: Parliament and the English Cotton Textile Industry, 1660-1774," The Economic History Review, New Series, Volume 44, Issue 3 (August), 395-423.

Olson, Mancur (1982) The Rise and Decline of Nations: Economic Growth, Stagflation, and Economic Rigidities, Yale University Press, New Haven and London.

Olson, Mancur (2000) Power and Prosperity: Outgrowing Communist and Capitalist Dictatorships, Basic Books, New York.

O'Rourke, Kevin H. and Jeffrey G. Williamson (2001) "After Columbus: Explaining the Global Trade Boom 1500-1800," Journal of Economic History, volume 62, March.

Pacey, Arnold (1991), Technology in World Civilization, MIT Press, Cambridge.

Parente Stephen and Edward C. Prescott (1999) "Monopoly Rights as Barriers to Riches," American Economic Review, 89, 1216-1233.

Parry, J.H. (1966) The Spanish Seaborne Empire, Berkeley; University of California Press. 
Pearl, Valerie (1961) London and the Outbreak of the Puritan Revolution; City Government and National Politics, 1625-43, London; Oxford University Press.

Phillips, Carla Rahn (1990), "The growth and composition of trade in the Iberian empires, 1450-1750," in The Rise of Merchant Empires: Long-Distance Trade in the Early Modern World, 1350-1750, edited by James D. Tracy, Cambridge University Press, Cambridge.

Pincus, Steven (1998) "Neither Machiavellian Moment nor Possessive Individualism: Commercial Society an the Defenders of the English Commonwealth," American Historical Review, 103, 705-736.

Pincus, Steven (2001) "From Holy Cause to Economic Interest: The Study of Population and the Invention of the State," in Alan Houston and Steven Pincus eds. A Nation Transformed: England after the Restoration, New York; Cambridge University Press.

Pincus, Steven (2002) "Civic Republicanism and Political Economy in an Age of Revolution: Law, Politics, and Economics in the Revolution of 1688-89," Unpublished, Department of History, University of Chicago.

Pomeranz, Kenneth (2000) The Great Divergence: Europe, China, and the Making of the Modern World Economy, Princeton University Press, Princeton.

Postan, M.M. (1975) The medieval economy and society : an economic history of Britain in the Middle Ages, Harmondsworth [Eng.] : Penguin.

Rajan, Raghuram G. and Zingales, Luigi (2000) "The Tyranny of Inequality" Journal of Public Economics vol 76, n3 521-58.

Rapp, Richard T. (1975) "The Unmaking of the Mediterranean Trade Hegemony: International Trade Rivalry and the Commercial Revolution," Journal of Economic History, 35, 499-525.

Rapp, Richard T. (1976) Industry and Economic Decline in Seventeenth-Century Venice, Cambridge MA; Harvard University Press.

Richardson, R.C. (1998) The Debate on the English Revolution, 3rd Edition, Manchester; University of Manchester Press.

Rogowski, Ronald (1989) Commerce and Coalitions: How Trade affects Domestic Political Alignments, Princeton; Princeton University Press.

Rokkan, Stein (1970) Citizens, Elections, Parties; Approaches to the Comparative Study of the Processes of Development, New York; McKay. 
Rosenberg, Nathan and L.E. Birdzell Jr. (1986) How the West Grew Rich: The Economic Transformation of the Industrial World, New York; Basic Books.

Royal Geographic Society (1997) Oxford Atlas of Exploration, Oxford University Press, Oxford.

Rudé, George (1972) Europe in the Eighteenth Century: Aristocracy and the Bourgeois Challenge, Cambridge MA; Harvard University Press.

Russell, Conrad (1990) The Causes of the English Civil War, New York; Oxford University Press.

Sacks, David H. (1991) The Widening Gate: Bristol and the Atlantic Economy, 1450-1700, Berkeley; University of California Press.

Scoville, Warren C. (1960) The Persecution of Huguenots and Franch Economic Development, 1680-1720, Berkeley: University of California Press.

Showers, Victor (1979) World Facts and Figures, Wiley, New York.

Smith, Adam [1776] (1999) The Wealth of Nations (Two Volumes), Penguin Classics, London.

Stearns, Peter N. (2001) The Encylopedia of World History, Sixth Edition, Houghton Mifflin Company, Boston.

Steensgaard, N. (1974), The Asian Trade Revolution of the Seventeenth Century, Chicago, 1974.

Stone, Lawrence (1972) The Causes of the English Revoluition, 1529-1642, New York; Routledge.

Sutherland, L.S. (1947) "The East India Company in Eighteenth-Century Politics," The Economic History Review, Volume 17, Issue 1, 15-26.

Tawney, R.H. (1941a) "The Rise of the Gentry, 1558-1640," Economic History Review, 11, 1-38.

Tawney, R.H. (1941b) "Harrington's Interpretation of his Age," Proceedings of the British Academy, 27.

Tilly, Charles (1990) Coercion, Capital, and European States, AD 990-1990, Cambridge MA; Basil Blackwell.

Thompson, I.A.A. (1994) "Castile: Absolutism, Constitutionalism and Liberty," in Philip T. Hoffman and Kathryn Norberg eds. Fiscal Crisis, Liberty and Representative Government, Stanford; Stanford University Press.

Tracy, James D. 1990, "Introduction," in The Rise of Merchant Empires: LongDistance Trade in the Early Modern World, 1350-1750, edited by James D. Tracy, Cam- 
bridge University Press, Cambridge.

Trevelyan, George M. (1938) The English Revolution, 1688-1689, London; T. Butterworth Ltd.

United Nations (UN) (1969) Growth of the World's Urban and Rural Population, 1920-2000, Department of Economic and Social Affairs, Population Studies, No. 44, New York.

Valone, James S. (1994) Huguenot Politics, 1601-1622, Lewiston: The Edwin Mellen Press.

Van der Wee, Herman (1990), "Structural changes in European long-distance trade, and particularly in the re-export trade from south to north, 1350-1750," in The Rise of Merchant Empires: Long-Distance Trade in the Early Modern World, 1350-1750, edited by James D. Tracy, Cambridge University Press, Cambridge.

Wallerstein, Immanuel M. (1974-1980) The Modern World-System, 3 Volumes, Academic Press, New York.

Weber, Max (1993) [1905] The Protestant Ethic and the Spirit of Capitalism, Routledge, London.

White, Lynn, Jr. (1962) Medieval Technology and Social Change, Oxford University Press, London.

Williams, Eric E. (1944) Capitalism and Slavery, University of North Carolina Press, Chapel Hill.

Wilson, Charles (1984), England's Apprenticeship 1603-1763, Longman, London, Second Edition.

World Bank (1999) World Development Indicators, CD-Rom and Book, Washington DC.

World Coal Institute (2000) Coal - Power for Progress, on the web at http://www.wcicoal.com/pfp.htm, March.

Zilibotti, Fabrizio (1995) "A Rostovian Model of Endogenous Growth and Underdevelopment Traps" European Economic Review vol 39, n8, 1569-1602. 


\section{Appendix (Not for Publication)}

\subsection{Country-Level Urbanization Data}

Our baseline data on European urban population are from Bairoch, Batou and Chèvre (1988). Bairoch, Batou and Chèvre start in $800 \mathrm{AD}$ (although their data are more reliable from $1300 \mathrm{AD}$ ) and include all cities in Eastern and Western Europe that crossed a threshold of 5,000 inhabitants at any time between 800 and 1800 (p. ix). We also use Bairoch (1988) for his qualitative assessment of country-level data, for his interpretation of some city-level information, and for urbanization estimates in India and China. ${ }^{47}$ We convert these urban population estimates to urbanization estimates using the total population numbers in McEvedy and Jones (1978).

We have checked Bairoch, Batou and Chèvre's estimates where possible against the data in de Vries (1984). De Vries's data, unfortunately, only start in 1500 AD and primarily cover Western Europe. For Western Europe, De Vries includes all cities with at least 10,000 inhabitants during 1500-1800. As a result, de Vries' urbanization estimates are generally lower, but the pattern over time, in particular the growth of Atlantic ports, is very similar. For example, de Vries (1984, p. 39) agrees that the level of urbanization in 1500 was very low in the British Isles $(2 \%)$ and low throughout northern Europe (3.3\%) with the exception of the Low Countries (18.5\%, with $21.1 \%$ in Belgium and $15.8 \%$ in the Netherlands). Urbanization was $6.1 \%$ in Spain and $12.4 \%$ for the whole of Italy (ranging from $11.4 \%$ in Central Italy to $15.1 \%$ in Northern Italy in 1550). This pattern is quite consistent with the numbers in Bairoch, Batou and Chèvre.

Irrespective of the precise definition of countries or the urbanization series we use, the available estimates support our main finding: the timing of urbanization increases during this period is closely correlated with increases in Atlantic trade. Bairoch (pp. 178$179,1988)$ points out that "new patterns of trade centering on the Atlantic" affected urbanization. Using a threshold of 5,000 inhabitants, the biggest change was in the Netherlands, where urbanization rose from 8-12\% in 1300 to $20-26 \%$ in 1500 and $38-49 \%$ in 1700 (the highest in Europe at that time). De Vries (1984, Table 3.7, p. 39), using a threshold of 10,000 inhabitants, shows a similar surge in urban percentage of total population: Portuguese urbanization jumped from 3\% in 1500 to $11.5 \%$ in 1550 and $14.1 \%$ in 1600 , Spanish urbanization rose from $6.1 \%$ in 1500 to $11.4 \%$ in 1600 , Dutch urbanization was $15.8 \%$ in 1500 and $33.6 \%$ in 1700, and urbanization in England and Wales rose from $5.8 \%$ in 1600 to $16.7 \%$ in 1750 . In contrast, urbanization changed little over this period in countries not connected closely to Atlantic trade: German urbanization was $3.2 \%$ in 1500 and only $5.5 \%$ in 1800 , Swiss urbanization was $1.5 \%$ in 1500 and $3.7 \%$ in 1800, and Polish urbanization was still only $1 \%$ in 1750.

\footnotetext{
${ }^{47}$ Bairoch (1988) was originally published in 1985 in French. The English edition reflects some revisions made through February 1988. Bairoch, Batou and Chèvre (1988) provide in large part the data on Europe that underlies much of the analysis in Bairoch (1988). These two sources should be seen as highly complementary.
} 


\subsection{City-Level Data}

We use city-level data in two ways. First, we use all cities for which Bairoch, Batou and Chèvre provide information in particular pairs of years. Second, we construct a balanced panel that contains only cities for which we have urban population data (from Bairoch, Batou and Chèvre) in 1300, 1400, 1500, 1600, 1700, 1750, 1800, and 1850. The balanced panel therefore includes only cities that have been in existence (and for which there are archival data) for a relatively long period of time. Overall, we have 193 European cities in the balanced panel. We also add data on 11 Asian cities from Chandler (1987) for robustness checks.

There are 13 Atlantic ports in our balanced panel. This list comprises almost all the cities that became major Atlantic ports through 1850. In Britain we have Plymouth, London, Bristol, and Glasgow. In the Netherlands we have Amsterdam, Dordrecht, and Middleburg. The Netherlands is a difficult country to code as most of the cities were on rivers or canals with easy access to the sea. We base our coding on whether a city is mentioned as a port in de Vries and van der Woude (1997). We have also tried an alternative coding which classifies all Dutch cities connected by water to the coast as ports. In France we have Rouen and Bordeaux, in Spain we have Seville and Santander, and in Portugal we have Porto and Lisbon.

There are also 8 "potential" Atlantic ports in our data, i.e., ports that could have become involved in Atlantic trade given their geographical location, but for various reasons were not. These are King's Lynn, Newcastle-upon-Tyne, Aberdeen, and Edinburgh in Britain, Dublin in Ireland, Antwerp in Belgium, and Hamburg and Bremen in Germany.

In our broader sample of cities, we have data on other cities that were involved in Atlantic trade, but which do not make it into our balanced panel. This supports our conclusions. For example, Nantes became an important French slave-trading city, but does not make it into our balanced panel as we are missing data for 1400 (Bairoch, Batou and Chèvre, p.28). This city started with a population of 8,000 in 1300 , reached 40,000 in 1700 and 77,000 in 1800 , a pattern of growth that is quite similar to that in Bristol (a major British slave-trade port that is in our balanced panel.) Rotterdam, for which we do not have data before 1500, rose from 5,000 inhabitants in 1500 to 51,000 in 1700. Liverpool, for which we also do not have data before 1500 , rose from 6,000 inhabitants in 1700 to 83,000 in 1800 and 376,000 inhabitants in 1850. Cádiz, for which we are missing data for 1400, rose from 2,000 inhabitants in 1300 to 40,000 in 1700 and 70,000 in $1800 .^{48}$

\footnotetext{
${ }^{48}$ The Spanish crown initially required that most Atlantic trade be run through Seville. However, Seville's port became partially blocked by a sandbar in 1718, and Cádiz became the official center for Spanish New World trade. From 1600 to 1700, Seville's population fell from 135,000 to 72,000 and Cádiz's population rose from 5,000 to 40,000. In the eighteenth century, Cádiz accounted for $75 \%$ of Spanish trade with America (see http://www.andalucia.com/cities/cadiz/history.htm). After Spain lost its colonies at the start of the nineteenth century, Cadiz's population declined.
} 


\subsection{Coding of Institutions}

The Polity dataset (now in version IV) codes various "institutionalized authority" characteristics of political regimes (Marshall and Jaggers, 2000). We use the Polity coding rules to assign a value of constraint on the executive before 1800 (the details are in the main text).

Where Polity IV provides a code for a country after 1800, we use that information. The earliest information in the Polity dataset is as follows (with the first year for which this code appears): 7 in the United Kingdom (in 1800), 1 in the Netherlands (in 1815, rising to 3 in 1840, 5 in 1848 and 6 in 1849), 5 in Belgium (in 1831, rising to 7 in 1853), 1 in France (in 1800, rising to 3 in 1814, 5 in 1830 and arriving, after some volatility, at 7 in 1877), 7 in Switzerland (in 1848), 1 in Spain (in 1800, rising to 3 in 1820, falling back to 1 in 1823, rising again to 5 in 1837, but falling steadily though 1867 and only reaching 7 in 1876), 1 in Portugal (in 1800, rising to 3 in 1834), 1 in German states (in 1800, rising to 3 only after 1848), 1 in Austria (in 1800, rising to 3 after 1860), 1 in all Italian states (rising to 3 only with unification in 1861), 1 in Serbia (in 1830), 1 in Greece (in 1827), 1 in Sweden (in 1800, rising to 3 in 1812), 3 in Norway (in 1814), 1 in Denmark (in 1800, rising to 5 after 1848) and 1 in Russia (in 1800). In general, we use a 40-year window around a date, e.g., we code 1800 as the average of 1780, 1790, 1800, 1810 and 1820. This avoids distortion due to a few unusual years.

The principle we follow, using Langer (1972), is to look for formal rules that constrain the executive in a way that matches the Polity criteria. If a monarch acted in a constrained way, e.g., imposing low taxes, but only because he or she chose to do so, this does not amount to a strong constraint on the executive. At the same time, however, we also look for evidence that formal rules were actually implemented.

Again we have to be careful when the political units that existed between 1500 and 1800 are not those that existed after 1800 (e.g., when the country entered the Polity dataset). To some extent therefore we have to map institutions at the level of political entities in 1500, e.g., the Duchy of Burgundy or the Hapsburg empire, into modern countries. For the most part this is not too difficult - Langer (1972) reports institutional developments at the level of modern countries, although we have to supplement his information on the Netherlands with the more detailed account in Israel (1995).

The main issues are with regards to Germany and Italy. Germany was comprised of many states during this period, but with only minor differences in institutions - all of them were run in a fairly autocratic fashion. With the exception of a few cities, we have not found evidence of strong constraint on the executive or protection for capital through 1800 anywhere in the modern borders of Germany.

Italy is more difficult because we know that institutions through 1500 at least were relatively pro-capital in the North and probably less so in the Papal States and in the Kingdom of Naples. Of course, there was arguably also significant variation within Northern Italy, for example between Venice, Milan, Genoa and Florence. We use an average measure of institutions, with Southern, Central and Northern Italy having equal weights. Within Northern Italy we assign equal weights to Venice, Milan, Florence and Genoa.

The only other coding of institutions before 1800 that we have found is from De Long 
and Shleifer (1993). The main difference in coding between following the Polity rules and using De Long and Shleifer (1993) is that the Polity coding rules imply feudal regimes had a weak constraint on the executive. De Long and Shleifer (1993) code regimes as either Free or Prince, and according to this scheme feudal regimes are "Free". Thus the move to absolutism in France after 1650 and Austria after 1500 (and by conquest, in Belgium and Italy) is a movement from Free to Prince, i.e., an equal and opposite move to that experienced by Britain when it moves from Prince to Free after 1650. ${ }^{49}$ In contrast, the Polity rules imply that the constraint on the executive in France before 1500 was not as high as, for example, in Britain in 1700, so the move to absolutism is a lower "step down" in terms of institutional quality. Nevertheless, the Polity rules applied to Langer (1972) produce the same qualitative conclusion as that of De Long and Shleifer (1993) for the period after 1500.

We also use an alternative coding of the protection for capital. We did this independently, using Langer to adjust constraint on the executive, so that a protection only counts if it is for "capital" (i.e., urban-based merchants of some kind) not for the nobility. In this view, early feudal regimes are almost as bad as absolutism almost everywhere and Poland, for example, never has good institutions.

Precise codings of this nature will always be controversial. But the qualitative ranking of institutions does not seem to be in doubt. The main points that emerge from our assessment are:

1. Institutions were roughly similar around 1500, with "better" institutions in the Low Countries, Northern Italy and Britain. In terms of the protection of capital, for example, Northern Italy was ahead of England and Spain in 1500 (a score of 3 vs. 2 for England and 1 for Spain). ${ }^{50}$ The only other places with a score of 3 in 1500 are Belgium and the Netherlands.

2. Institutions became worse from 1500 to 1750 in countries that experienced absolutist regimes (e.g., France, Austria, Italy, Germany and to some extent Spain). This seems quite uncontroversial - parliaments ceased to meet in general, religious (trading) minorities such as the Huguenots and Jews were mistreated and eventually expelled. In all these "absolutist" countries, constraint on the executive fell from an initial score of 2 or 3 to a score of 1 . Institutions improved in France from the end of the eighteenth century, although the French Revolution was associated with considerable political volatility.

3. Institutions "improved", with stronger constraint on the executive and more protection of capital, from 1500 to 1700 in Britain and the Netherlands. In the Netherlands

\footnotetext{
${ }^{49}$ De Long and Shleifer also code Tilly (1990) and use a scheme proposed by Putnam. All variants of their codings produce similar results for our analysis.

${ }^{50}$ According to Langer (1972), the Cortes (parliament) had some significant powers in Castille around 1400 in Spain. However, this did not last, in part because the monarch gained access to large cash revenues in the form of gold and silver from the New World. The Inquisition also played an important part in undermining property rights (Kamen, 1965). Catalonia had relatively good initial institutions but was undermined by the Castilian monarchy (and of course does not have direct access to the Atlantic). In contrast, city charters and customary rights provided considerable constraint on the executive in the Low Countries, primarily by limiting the ability of the sovereign to tax. The constraint on the executive was probably higher in the Netherlands, but not by much in 1400: we assign a score of 3 to the Netherlands and a score of 2 to Spain.
} 
the key event was the struggle for independence, as discussed in the text. The independent Netherlands was probably the place between 1600 and 1750 with the strongest protection for the rights of capital - there was a nominal head of state, but the real power was at the level of cities and regional assemblies (see Israel, 1995). Through 1850 institutions continued to improve in Britain, particularly with the steady strengthening of Parliament, but not in the Netherlands. According to the Polity data, Britain reached a score of 7 by 1800 (the highest possible measure of constraint on the executive) while the Netherlands, after a period of Napoleonic rule, reached only a 3 by 1840 .

\subsection{Estimates of Trade Levels}

\subsubsection{Units of Measurement}

We measure the number of annual average voyages-equivalent, where one "voyageequivalent" is defined to be the round-trip of a ship with a deadweight tonnage (i.e., carrying capacity without overloading) of 400 tons. Deadweight tonnage was a standard measure in the age of sail (see Lane, 1934, p .246). ${ }^{51}$

While 400 tons is larger than European ships in medieval times, it is smaller than many of the long-distance sailing ships in use by 1600 . Venetian merchant galleys had a carrying capacity of 110-115 metric tons in 1318-20, 170 metric tons in 1420 and 280 metric tons in 1549-59 (Maddison, 2001, Table 2-2, p. 54.) Portuguese Atlantic trade ships averaged about 400 tons in early 1500s, rising to 600 tons in mid-1500s, and by 1600 had some carracks of 1000-1500 tons; subsequently, however, long-distance trading ships became smaller (Phillips, 1990, de Vries, 2002).

\subsubsection{Mediterranean Trade}

To construct a series for Mediterranean trade comparable with our estimates of Atlantic trade, we measure the trans-Mediterranean trade between Western Europe in the Mediterranean (particularly Italy and Spain) and the Levant broadly defined (in particular, Constantinople, Syria, and Egypt). Thus we are not counting local coastal trade between Italian ports or within the Adriatic. We are also not counting trade between Britain or the Netherlands and the Levant.

The best quantitative evidence on trans-Mediterranean trade in this period is for Venice. From the second quarter of the fifteenth century (van der Wee 1990, p.20), Venice was "leading commercial and financial center of Europe". Catalonian and Valencian ports also had a strong position in Mediterranean trade in the 15th century, and Genoa was also strong at least until 1500. But Venice held Mediterranean trade supremacy from the sack of Constantinople in 1208 at least until 1700.

\footnotetext{
${ }^{51}$ While there are differences in the measure of "tons" used by various sources, these are not large enough to affect our analysis. A long ton (the standard British measure) is a unit of mass in the avoirdupois system of units equal to 2240 pound-masses or 20 long hundredweights. A long ton weighs $1016 \mathrm{~kg}$, while a short ton (the standard U.S. measure) is $2000 \mathrm{lb}(907 \mathrm{~kg})$. A metric tonne is $1000 \mathrm{~kg}$. The Spanish tonelada is equal to approximately 2000 English pounds (i.e., a short ton). The English ton, derived from the wine tonneau of Bordeaux, was one tenth larger (what mariners still call today a "long ton"). One English ton equaled four large barrels, or hogsheads.
} 
The Venetian merchant marine comprised two very different kinds of ships: galleys and cogs. Galleys were large and regarded as good defensive and offensive naval vessels. They were often preferred for the most valuable cargoes. Cogs varied in size, but the largest were bigger than the ships used in the early Atlantic trade. These large cogs were strong in defense, but could not effectively attack galleys before ship-mounted cannon became viable.

At the time of Doge Mocenigo (1420-1450), 45 state galleys sailed each year: 3 to Romania and the Tana (Romania is here a geographical term which at the time included Greece, with particularly important trade on the Peloponnesian peninsula; Tana is in the Black Sea at the mouth of the Don); 4 to Flanders and England; 3 to Alexandria; 4 to Beyrut (sic) and 2 to Aigues Mortes (near Marseilles) in France (Lane, 1934, p. 253). Two or three private galleys sailed with pilgrims each year to Jaffa. ${ }^{52}$ Lane (1934, pp. 253-4) writes, "Of other private galleys I have found no mention."

In the first half of the fifteenth century, there were two voyages a year from Venice to Syria (organized by the state). For the eight years of most frequent records, there were an average of 5.75 cogs per year (1420s and 1430s) with total capacity of 4966 botte (the conversion is to multiply by $2 / 3$ to get tons, i.e. 3,311 tons, so the cogs had a carrying capacity of 575 tons each). In the early 1400s there were in the Venetian merchant marine at least 6 ships of 1000 botte or over (Lane, 1934, p. 256).

According to Lane (1944, p. 257) there were about 15-16 ships (i.e., cogs) per year sailing to Syria/Cyprus and to Constantinople in both 1448 and $1558 .{ }^{53}$ The total number botte was only slightly higher in 1558 (15,000, i.e., about 10,000 tons or 25 voyage-equivalents using our measure of 400 tons per voyage)

Our estimate of 40 Mediterranean voyages per year in 1400 and 50 in 1500. More recent research on trade levels within the Mediterranean after 1500 confirms this overall pattern. Initial trade levels were quite low. "In the mid-fourteenth century, just after the arrival of the Black Death, Venice sent an average of one ship to the Levant every two years. By the end of the fifteenth century an annual average of five to seven galleys made the trip. In the mid-fifteenth century Venetians also sent a dozen "round ships" a year to Syria" (Phillips, 1990, p. 37). Table 2.1 (Phillips, 1990, p. 40) gives ships per year for Venice as 7.5 in 1391-1400 and 6.1 in 1441-50. Genoa sent 6 ships of all types to the Levant in the late 1360s (p. 38). Catalonia, "whose trade ran far behind that of Venice and Genoa", sent 2 ships per year to the Levant in the end of the 1300s and 5-6 during the 1420s, and 4.5 ships per year in 1450s and 1460s. The level of Mediterranean trade remained roughly constant from 1500 to 1700 (Phillips, 1990).

After the Portuguese expansion into Indian Ocean, there was some initial fall in the spice trade through the eastern Mediterranean. But as Tracy (1990, p. 8) points out, despite repeated attempts, the Portuguese did not capture Aden, so they could not control Bab el Mandeb (the 14 mile wide strait that connects the Indian Ocean with the Red Sea). Thus they were not able to fully control flow of pepper and fine spices. The

\footnotetext{
${ }^{52}$ These were not quick voyages, with usually one round trip per year. The voyage to England took a year.

${ }^{53}$ At around this time, Venice also had about 300 navi, which were round ships of about 100 tons or larger (Lane, p. 254).
} 
Venetians were able to carry on their traditional spice trade at Alexandria (Lane, 1940). Van der Wee (1990, p.15) puts it as follows, "The discovery of alternative sea routes to Asia around 1500 by Portugal and Spain disturbed Italy's dominant position [in re-exporting goods from Near and Far East], but it did not lead to an immediate decline in its re-export trade from south to north." However, Venetian and other transMediterranean trade was roughly stagnant from the start of seventeenth century.

Note that the Dutch grabbed an increasing share of shipping to the Mediterranean, particularly as they developed markets for colonial re-exports. Their shipping to this area comprised 4,129 tons in 1591-1600 and 15,789 tons in 1601-10. It was 9,298 tons in 1701-10 and 13,952 tons in 1711-20 (equivalent to 3.5 standard 400 ton voyages per year and much smaller than their Asian trade) (de Vries and van der Woude, 1997, p.381).

\subsubsection{Atlantic Trade}

There is no complete series of "Atlantic trade" statistics. We use four series based on three separate sources, all of which agree on the main points. De Vries (2002) provides the latest estimate of trade from Europe to Asia. His estimates are by decade, so we convert these into an estimate for a particular year. We supplement this information with estimates from other sources of the level of trade between Europe and the Americas. Our main sources are the recent essays in Tracy (1990), but we also use information from the classic Davis (1962) and Steensgaard (1974). Note that the Africa trade was largely "triangular," i.e., involved goods to Africa, slaves to the Americas, and agricultural products to Europe on the same trip.

We also construct two alternative estimates of Atlantic trade from O'Rourke and Williamson (2002). They give growth rates, but not levels, of long-distance trade from 1500 to 1850 . We apply these rates to our estimates of initial trade (in annual voyagesequivalent) to give an estimate of trade in each year. (We have also checked our results using an alternative Williamson-O'Rourke based series, with a much lower starting point for trade in 1500 and no growth from 1400 to 1500. Using this series does not change our findings in any substantive way).

Inikori (1992) gives the following estimates of Atlantic trade, including services and intra-American trade (all in British pounds): 14.7 for middle decades of seventeenth century, 38.4 for middle decades of eighteenth century, 102.7 for last decades of the eighteenth century. This is somewhat lower growth between 1650 and 1750 (growth by a factor of 2.61 versus our estimate of 3.86) and slightly higher growth between 1650 and 1800 (a factor of 6.99 versus our estimate of 6.45). Overall, this series is white consistent with our estimates and using this does not change our main results.

\section{Trade in 1500}

In 1500, most of the "Atlantic" trade was Spanish and Portuguese. The Spanish traded almost exclusively with the Americas and the Portuguese traded primarily with Asia (their trade with Brazil was low at this time.) We do not have estimates from the literature for 1500 precisely, but there are good numbers for the first few decades of the sixteenth century. For 1506-10, there were 45.2 ships to and from the Spanish West Indies per year, rising through the century (Table 2.1 in Philips 1990). The average 
weight of these ships was 99.1 tonnelada, i.e., about $\frac{1}{4}$ of our standard measure of 400 tons. A ship could make at least one round-trip per year and our data are for sailings to and from the Spanish West Indies. Most of the Spanish ships were around 100 tons deadweight at this time.

The round-trip from Lisbon to Goa could take from 6 to 18 months (Phillips, 1990, p. 49), depending on the weather. "Between 1500 and 1635, about seven ships left Lisbon each year for India, and about four began the return trip" (p. 49). Around the end of the 1500s, losses on outbound Portuguese voyages were about $11 \%$ and $15 \%$ on inbound (Phillips, 1990, p. 53). Maddison (2001, Table 2-7, p. 64) reports that the average duration of the outward trip from Lisbon to Cochin was about 5.75 months and the return took 6.5 months "once the trade was firmly established."

Maddison (2001) provides a good crosscheck on our data as he compiles comparable numbers from various secondary sources. Maddison (2001, Table 2-7) reports annual average voyages from Lisbon to the Indian Ocean as 9.0 in 1500-49 and 5.1 in 1550-99. There were fewer return journeys (5.2 per year 1500-49 and 4.2 per year 1550-99) in part due to ship losses but also because some ships stayed in Asia. The intra-Asia trade was highly profitable in these early years - see de Vries (2002) for estimates of the use of European ships in this trade. Pacey (1991) discusses how and why Europeans used ships built in India for intra-Asian trade, so a great deal of this trade will not show up in our data on voyages in and out of Europe.

De Vries (2002) puts the number of Portuguese voyages from Europe to Asia as 151 in 1501-10. The number of ship departures falls over the century in his data, but tonnage per ship rises, so that outbound Portuguese tonnage in 1501-10 was 42,778 and 49,201 in 1591-1600. De Vries' (2002) data show that the English entered the Europe-Asia trade only in 1581-90 (with 11 ships in the decade, with a total of just 5,060 tons) and the Dutch entered only in 1591-1600. However, the Dutch quickly reached high levels of activity-more than half the Portuguese tonnage in the first decade and passing Portuguese levels by 1630 .

Total tonnage to Asia from de Vries (2002) from 1501-1600 is 465,144, which is 1,163 "400 ton equivalent voyages" over the whole 100 years. Total return tonnage from Asia was somewhat less: 320,735 or 802 "equivalent voyages" over the century. Total equivalent round-trip voyages are therefore 802 plus 181, which is equivalent to about 10 per year. ${ }^{54}$

Therefore our main estimate for Atlantic trade in 1500 is 11.3 Spanish "standard" voyages (45.2 divided by 4 ) plus 8.8 voyages to Asia, mostly Portuguese, for a total of 20.1 voyages per year. For our alternative estimate, using the O'Rourke and Williamson growth numbers, we use the same starting level (but we have checked our results using

\footnotetext{
${ }^{54}$ As a crosscheck on these estimates of ship size, consider the amount of spice production (from Curtin, 1984, p.131), keeping in mind that the early Portuguese ships carried primarily spices (Maddison, 2001, p.84). In the second half of the fifteenth century, annual production of mace was about 100 metric tons and production of nutmeg was about 1200 tons (both from the Banda Islands). Production of cloves, from Maluku (sic), was about 1200 tons. Apparently production was lower when the Europeans dealt directly with the islands. According to these sources, Sumatra exported as much pepper in the fifteenth century as it did at its eighteenth-century peak. Pepper came from India as well as Sumatra.
} 
an alternative, lower level of 1). Note that this implies a relatively small percentage increase from 1400 to 1500 (compared to later rates of increase) - this is reasonable as by all accounts there was relatively little Atlantic trade until the Spanish conquered the Aztecs and Incas. Our estimate of Dutch and British Atlantic trade at this date is zero.

\section{Trade in 1600}

By 1600 the Dutch had made substantial inroads into the Asian trade (de Vries 2002), but the Portuguese remained important. Most of the trade with the Americas was through Spain, but the British were starting to have an impact here. Overall, the level of trade through the Atlantic probably passed the level of trade through the Mediterranean around $1600 .{ }^{55}$

In 1596-1600 there were 188.6 ships to and from the Spanish West Indies per year. Phillips (1990), p.88, writes, "In the late 1620s, there were still nearly 120 ships per year in the Indies trade... [to and from Spain]... By the late 1640s, an annual average of fewer than 75 ships carried the trade, and from the late 1650s to the late 1660s, between 30 and 35 ships."

According to Phillips (1990, Table 2.1), Spanish ships going to and from the West Indies in 1596-1600 had an average weight of 236.2 tonneladas. Note that our measure is a round-trip voyage, and there is some danger of double counting on the West Indies route (less likely a problem on the Asian route). Dividing this Spanish estimate by 2 for round-trip voyage equivalents of 400-ton ships seems reasonable.

There were also some British voyages, but these were mostly small-scale piracy (run by the likes of Hawkins and Drake). These were more ad hoc occasional expeditions than regular trade, although they were highly profitable and created the basis for the navy that defeated the Spanish Armada in 1588.

From de Vries (2002) we have total outbound tonnage from Europe to Asia of $1,745,318$ from 1601-1700, which is about 44 voyages per year (in 400 ton equivalent units). Return tonnage, however, was only 871,334 for the century, which is about 22 voyages per year. Therefore we take return trip equivalent voyages to be 33 per year.

In 1602-25 Holland sent an average of 10 ships per year to Asia, while in the 17th and 18th centuries, Portuguese sent 10-20 ships each year to Goa (Phillips, 1990, p. 54). Maddison (2001, Tables 2-7) reports annual average voyages "departures" from Lisbon to the Indian Ocean as 5.8 in 1600-35 and 2.5 in 1636-1700.

Therefore our base estimate is 63 Spanish voyages (188.6 divided by 3, rounding up) plus 33 voyages from Europe to Asia, including the Portuguese, Dutch and British, for a total of 96 voyages. Our alternative estimate from the O'Rourke and Williamson method is 71.5 voyages. Our estimate of Dutch trade at this time is 10 voyages and our estimate of British trade is 5 voyages.

Trade in 1700

By 1700 most of the "Atlantic trade" was Dutch and British. However, in 1695-99 there were still 35 ships per year to and from the Spanish West Indies. There was a rise

\footnotetext{
${ }^{55}$ Phillips (1990, p. 82) points out that the export of silver from Venice to the Levant in 1610-14 was worth about $5.7 \%$ of total value of silver arriving in Seville in same period. She sees this as evidence that the Levant trade "far smaller" than Indies trade.
} 
from about 30 ships per year in the late 1710 s to about 100 ships per year in the late 1770s (Phillips 1990, p.98). We do not have a weight estimate for those years, but in 1717-20 the average size of a ship on this route was 296.5 toneladas (Philips 1990, Table 2-1). Again, we need to adjust for the fact that a ship doing a round-trip voyage will be counted twice in these statistics.

Maddison (2001, Table 2-7) reports annual average voyages "departures" from Lisbon to the Indian Ocean as 1.9 in 1701-1800. In 1671-1750, Holland sent an average of 29 ships per year to Asia

The shipping tonnage engaged in England's overseas trade was as follows (Davis, 1962, p. 17): in 1663, for America and West Indies, 36,000, and for East India, 8,000; in 1686, for America and West Indies, 70,000, and for East India, 12,000; in 1771-3, for America and West Indies, 153,000, and for East India, 29,000. East India tonnage was fairly consistently $1 / 5$ of America and West Indies tonnage.

Davis (1962), p.15, puts England's total merchant shipping tonnage at 150,000 tons in 1640 and 340,000 in 1686. Transoceanic trade was essentially zero in 1600, rising to over $40 \%$ of overseas trading tonnage in 1686 (i.e., before the Glorious Revolution). Through 1713, however, there was little additional increase in merchant tonnage and perhaps some decline (Davis 1962, p.25).

From Davis (1962), p.200, shipping tonnages in 1686 for clearances (outbound) were as follows (we divide by 400 for voyage equivalents). From all English ports to the Mediterranean, 18,800 tons, which is equivalent to 47 voyages; to East India 8,400; to the West Indies, 34,000; and to North America: 33,100. Therefore "Atlantic" trade (last three categories) comprised 75,500 tons, or 189 equivalent voyages (and was four times the level of Mediterranean trade). The ratio of East India voyages to West Indies/North America voyages was 8 .

De Vries (2002) puts total outbound Europe-Asia tonnage in 1701-1750 at 1,897,377 and 1751-1795 at 2,623,906. This implies equivalent outbound "standard" voyages of 95 and 146 for the two half-centuries respectively, i.e., a doubling of the levels 1601-1700. The return tonnage numbers imply 71 voyages per year in both half centuries.

For 1701-1710, de Vries (2002) has outbound Europe-Asia tonnage at 266,909, which is 667 one-way voyages (in our equivalent units) or 67 per year. Return tonnage is 164,357 in his series, which is 411 one-way voyages or 41 per year. For 1700 we take round-trip voyages to be 41 plus 13, i.e., 54 .

According to de Vries (2002), British voyages to Asia were 40,445 tons in 1701-05, which is equivalent to about ten 400-ton voyages per year (this is half the level from Davis, p.200, for 1686; de Vries numbers imply about a $25 \%$ fall over this period, using decade averages - there was some general European-wide depression in trade). Assuming British voyages to the Americas were 8 times the level to Asia gives 80 voyages per year. We assume French trade to the Americas was about 20 equivalent voyages (this is approximately the ratio from the slave trade at this time.)

Therefore our base estimate for Atlantic trade in 1700 is 12 Spanish voyages (35 divided by 3) plus 54 Portuguese, Dutch, British, French and others voyages to Asia plus 80 voyages by the British to the Americas plus 20 voyages by the French to the 
Americas, giving 166 voyages total. ${ }^{56}$ Our estimate from O'Rourke and Williamson is 152 voyages. Our estimate of Dutch trade is 29 voyages and our estimate of British trade is 90 voyages (note that this would have been much higher in 1686, but trade was quite depressed around 1700).

Trade in 1750

In 1750 most of the "Atlantic" trade was British, French and some Dutch. In 1746-50 there were 51.4 ships to and from the Spanish West Indies.

For 1751-60, de Vries (2002) has outbound Europe-Asia tonnage of 520,662, which is 130 equivalent one-way voyages per year, and return tonnage of 405,039, which is 101 equivalent voyages. We take 115 per year as our estimate.

From Phillips (1990), in 1671-1750 Holland sent an average of 29 ships per year to Asia. British voyages to Asia in 1751-60 amounted to 85,823 tons, which is 21 voyages per year; voyages to the Americas (using the 5x multiple) would have been 105 . North (1968) confirms that tobacco ships made only one round trip per year, spending approximately 100 days in port in the Americas, waiting for and loading cargo. There was some speeding up of turnaround from the mid-eighteenth century.

Davis (1962, p. 200) has clearances from English ports in 1715-17 and 1771-73 (both are totals for 3 year periods). We take the average of the two estimates for each type of trade. This would put clearances for East India (i.e., Asia) at 3,033 tons per year. ${ }^{57}$ Clearances for the West Indies would be 23,367 tons and clearances for North America would be 23,217 tons. These estimates for clearances to the Americas imply total voyage equivalents of 349 voyages (assuming two or more round-trips per year; see North, 1968, on the improvement in sailing time.)

The evidence on French trade to the Americas is more limited. We rely on the qualitative analysis in Butel (1997) to arrive at a rough estimate of 25 standard voyages equivalent.

Therefore our main estimate for 1750 is 17 Spanish voyages (51.4 divided by 3 ) plus 115 total voyages to Asia, including Portuguese, Dutch, British, French and others, plus 349 British voyages to the Americas, plus 25 French voyages to the Americas, for a total of 506 standard equivalent voyages. From O'Rourke and Williamson (2001) we have an alternative estimate of 383 voyage-equivalents. Our estimate for Dutch trade is 29 voyages and our estimate of British trade is 356 voyages.

\section{Trade in 1800}

In 1800 most of the Atlantic trade was in the hands of the British and French. However, in 1776-78, there were still 102.7 ships traveling to and from the Spanish West Indies (Phillips 1990).

For 1781-90, the last full decade in his data, de Vries (2002) has total outbound Europe-Asia tonnage as 673,940, which is 1,685 "400-ton voyages" or 169 per year. He

\footnotetext{
${ }^{56}$ This is consistent with Hamilton (1938, p. 170), "From the last quarter of the sixteenth century to the last quarter of the seventeenth the tonnage of the ships plying between Spain and the Indies fell by approximately 75 per cent."

${ }^{57}$ Note that de Vries has a similar estimate for this time period - he puts outbound tonnage from England to Asia as 49,605 in 1711-20, i.e., an average of around 5,000 tons per year.
} 
puts inbound Asia-Europe tonnage at 206,900, which is 52 equivalent voyages per year. We take 111 voyages per year as our estimate, i.e., approximately the same level as in $1750 . .^{58}$

Direct estimates of British trade to the Americas are available from Davis, 1962, p.200. Clearances in 1771-73 (over the three year period) were 13,900 tons to the East Indies, 104,500 to the West Indies (including the slave coasts of Africa), and 99,000 to North America. Total tonnage to these destinations was 217,400 over three years (up from 80,300 in 1715-17). However, there was also an increase in productivity (North, 1968). We estimate total voyage equivalents, excluding Asia, in 1771-73 to be 508.75 .

British voyages to Asia were 228,315 tons in 1781-90 (de Vries, 2002), which are equivalent to 57 voyages per year. British (and American) equivalent-voyages to the Americas, we assume were around 600 - there was some disruption of trade due to the war of independence, but trade grew quickly thereafter.

French trade to the Americas was severely disrupted by the French Revolution and consequent civil war. Even more important, was the loss of sugar production when Haiti rebelled, defeated the army sent to subdue it, and became independent. From Butel (1997) we infer French standard-equivalent voyages of 100.

Therefore our main estimate for 1800 is 34 Spanish (102.7 divided by 3) plus 111 total to Asia, including Portuguese, Dutch, British and others, plus 600 British (and American) to the Americas, plus 100 French to the Americas, for a total of 845 . From the O'Rourke and Williamson (2001) alternative method we have 676 voyages. Our estimate of Dutch voyages is 40 voyages and our estimate of British voyages is 657 .

\section{Trade in 1850}

At this date most of the Atlantic trade was British, French, and American. We do not have total tonnage of shipping for this year. However, from Maddison, 2001, p.95, we know the total carrying capacity of world shipping in various years. This generally tracks Atlantic-trading volumes well. In tons, "sail equivalent", shipping capacity was 320,000 tons in $1470,730,000$ in $1570,1,450,000$ in $1670,3,950,000$ in $1780,5,880,000$ in 1820 (20,000 tons of which were steam), and 14,600,000 in 1850 (800,000 tons of which were steam). Of these totals, 100,000 is Maddison's (2001) estimate of Asian countries' shipping from $1470-1780 . .^{59}$

For our baseline estimate, we therefore assume that Atlantic trade increased in the same proportion as shipping tonnage between 1800 and 1850, i.e., by a factor of 3 . This puts our baseline Atlantic trade estimate at 2,535 voyages. From O'Rourke and Williamson's (2001) rapid growth rate for trade in this period we have trade in 1850 as 3762.7 equivalent voyages. Our estimate of Dutch trade is 120 voyages and our estimate of British trade is 1971 voyages.

\footnotetext{
${ }^{58}$ In 1750-80, Holland sent an average of 26 ships per year to Asia (Phillips, 1990).

${ }^{59}$ Note that Maddison (2001) assumes that one steam ton is equivalent to 4 sail tons due to increased productivity, primarily a higher average speed of sailing (see also North 1968). For more on the tonnage of English owned shipping, see Davis (1962, pp. 26-27). London comprises about half of total tonnage in 1686 , falling to about one-quarter in 1786 .
} 
Table 1

Descriptive Statistics

\begin{tabular}{|c|c|c|c|c|c|c|}
\hline & $\begin{array}{c}\text { Whole } \\
\text { Sample, } \\
\text { unweighted }\end{array}$ & $\begin{array}{c}\text { Whole } \\
\text { Sample, } \\
\text { weighted }\end{array}$ & $\begin{array}{c}\text { Atlantic } \\
\text { Western } \\
\text { Europe }\end{array}$ & $\begin{array}{c}\text { Non- } \\
\text { Atlantic } \\
\text { Western } \\
\text { Europe } \\
\end{array}$ & $\begin{array}{l}\text { Eastern } \\
\text { Europe }\end{array}$ & Asia \\
\hline & & & \multicolumn{4}{|c|}{ Weighted by population } \\
\hline Urbanization in 1300 & $\begin{array}{c}6.6 \\
(5.2)\end{array}$ & $\begin{array}{c}9.9 \\
(3.2)\end{array}$ & $\begin{array}{l}8.0 \\
(2.8)\end{array}$ & $\begin{array}{l}10.0 \\
(6.1)\end{array}$ & $\begin{array}{l}4.1 \\
(3.3)\end{array}$ & $\begin{array}{l}11.0 \\
(0.7)\end{array}$ \\
\hline Urbanization in 1400 & $\begin{array}{l}7.6 \\
(9.5)\end{array}$ & $\begin{array}{l}10.3 \\
(3.6)\end{array}$ & $\begin{array}{l}8.5 \\
(2.4)\end{array}$ & $\begin{array}{c}12.1 \\
(10.0)\end{array}$ & $\begin{array}{l}3.9 \\
(1.5)\end{array}$ & $\begin{array}{l}11.1 \\
(0.5)\end{array}$ \\
\hline Urbanization in 1500 & $\begin{array}{c}8.3 \\
(7.6)\end{array}$ & $\begin{array}{l}10.6 \\
(3.4)\end{array}$ & $\begin{array}{l}10.1 \\
(5.3)\end{array}$ & $\begin{array}{l}11.4 \\
(6.8)\end{array}$ & $\begin{array}{l}4.0 \\
(1.8)\end{array}$ & $\begin{array}{l}11.5 \\
(0.7)\end{array}$ \\
\hline Urbanization in 1600 & $\begin{array}{c}9.6 \\
(7.6)\end{array}$ & $\begin{array}{l}11.7 \\
(4.0)\end{array}$ & $\begin{array}{l}13.6 \\
(7.6)\end{array}$ & $\begin{array}{l}14.0 \\
(8.8)\end{array}$ & $\begin{array}{l}4.4 \\
(2.7)\end{array}$ & $\begin{array}{l}12.0 \\
(0.7)\end{array}$ \\
\hline Urbanization in 1700 & $\begin{array}{l}10.7 \\
(8.5)\end{array}$ & $\begin{array}{l}11.2 \\
(4.1)\end{array}$ & $\begin{array}{l}14.5 \\
(6.8)\end{array}$ & $\begin{array}{l}13.1 \\
(8.1)\end{array}$ & $\begin{array}{l}3.7 \\
(2.2)\end{array}$ & $\begin{array}{l}11.6 \\
(0.7)\end{array}$ \\
\hline Urbanization in 1800 & $\begin{array}{l}14.1 \\
(9.1)\end{array}$ & $\begin{array}{l}10.3 \\
(4.9)\end{array}$ & $\begin{array}{l}19.8 \\
(7.9)\end{array}$ & $\begin{array}{l}16.9 \\
(7.5)\end{array}$ & $\begin{array}{l}7.0 \\
(3.3)\end{array}$ & $\begin{array}{l}8.9 \\
(1.4)\end{array}$ \\
\hline GDP per capita in 1500 & $\begin{array}{l}627.54 \\
(159.3)\end{array}$ & $\begin{array}{l}608.3 \\
(118.0)\end{array}$ & $\begin{array}{c}721.46 \\
(31.1)\end{array}$ & $\begin{array}{l}850.73 \\
(217.1)\end{array}$ & $\begin{array}{c}506.94 \\
(78.2)\end{array}$ & $\begin{array}{c}575 \\
(35.4)\end{array}$ \\
\hline GDP per capita in 1600 & $\begin{array}{l}740.73 \\
(225.6)\end{array}$ & $\begin{array}{c}630.5 \\
(144.2)\end{array}$ & $\begin{array}{l}916.31 \\
(149.3)\end{array}$ & $\begin{array}{l}908.22 \\
(167.3)\end{array}$ & $\begin{array}{l}578.29 \\
(112.3)\end{array}$ & $\begin{array}{l}576.8 \\
(35.3)\end{array}$ \\
\hline GDP per capita in 1700 & $\begin{array}{l}862.12 \\
(348.4)\end{array}$ & $\begin{array}{c}622.2 \\
(208.1)\end{array}$ & $\begin{array}{c}1079.21 \\
(321.4)\end{array}$ & $\begin{array}{l}980.82 \\
(128.2)\end{array}$ & $\begin{array}{c}636.0 \\
(136.1)\end{array}$ & $\begin{array}{l}574.2 \\
(35.3)\end{array}$ \\
\hline GDP per capita in 1820 & $\begin{array}{l}988.00 \\
(373.6)\end{array}$ & $\begin{array}{c}691.7 \\
(264.5)\end{array}$ & $\begin{array}{l}1321.95 \\
(348.7)\end{array}$ & $\begin{array}{c}1095.40 \\
(125.3)\end{array}$ & $\begin{array}{c}719.5 \\
(174.9)\end{array}$ & $\begin{array}{l}575.5 \\
(45.7)\end{array}$ \\
\hline Constraint on Executive in 1500 & $\begin{array}{l}1.67 \\
(0.76)\end{array}$ & $\begin{array}{l}1.73 \\
(0.79)\end{array}$ & $\begin{array}{l}1.80 \\
(0.59)\end{array}$ & $\begin{array}{l}1.99 \\
(0.99)\end{array}$ & $\begin{array}{l}1.46 \\
(0.79)\end{array}$ & \\
\hline Constraint on Executive in 1600 & $\begin{array}{l}1.67 \\
(1.01)\end{array}$ & $\begin{array}{l}1.53 \\
(0.84)\end{array}$ & $\begin{array}{c}1.65 \\
(1.15)\end{array}$ & $\begin{array}{l}1.54 \\
(0.59)\end{array}$ & $\begin{array}{l}1.45 \\
(0.79)\end{array}$ & \\
\hline Constraint on Executive in 1700 & $\begin{array}{c}1.83 \\
(1.31)\end{array}$ & $\begin{array}{l}1.52 \\
(1.17)\end{array}$ & $\begin{array}{c}1.96 \\
(1.71)\end{array}$ & $\begin{array}{l}1.41 \\
(0.94)\end{array}$ & $\begin{array}{l}1.30 \\
(0.76)\end{array}$ & \\
\hline Constraint on Executive in 1800 & $\begin{array}{l}2.25 \\
(1.82)\end{array}$ & $\begin{array}{l}2.18 \\
(1.83)\end{array}$ & $\begin{array}{l}4.16 \\
(1.72)\end{array}$ & $\begin{array}{l}1.90 \\
(1.78)\end{array}$ & $\begin{array}{l}1.00 \\
(0.00)\end{array}$ & \\
\hline Atlantic Coast-to-Area & $\begin{array}{l}0.0057 \\
(0.0117)\end{array}$ & $\begin{array}{l}0.0014 \\
(0.0065)\end{array}$ & $\begin{array}{l}0.0118 \\
(0.0181)\end{array}$ & $\begin{array}{l}0.0026 \\
(0.0052)\end{array}$ & 0.00 & 0.00 \\
\hline $\begin{array}{l}\text { Average Population in } \\
\text { Atlantic Ports }\end{array}$ & $\begin{array}{l}1.15 \\
(2.53) \\
\end{array}$ & $\begin{array}{c}0.25 \\
(1.18) \\
\end{array}$ & $\begin{array}{l}2.34 \\
(3.22) \\
\end{array}$ & $\begin{array}{l}0.18 \\
(0.66) \\
\end{array}$ & 0.00 & 0.00 \\
\hline
\end{tabular}

First column is unweighted means; other columns are mean values weighted by total population in year indicated. Standard deviation is in parentheses. There are 24 European countries in these data. Atlantic Western Europe is England, France, the Netherlands, Portugal, and Spain. Non-Atlantic Western Europe is Austria, Belgium, Denmark, Finland, Germany, Ireland, Italy, Norway, Sweden and Switzerland. Eastern Europe is Albania, Bulgaria, the Czech Republic, Greece, Hungary, Poland, Romania, Russia, and Serbia. Asia is India and China. Urbanization for Europe is percent population living in towns where the population was at least 5,000, at some time between 800 and 1800, from Bairoch, Batou and Chèvre for Europe; comparable data for Asia are from Bairoch. GDP per capita is from Maddison. Constraint on executive is on a scale from 1 to 7 , where a higher score indicates more constraints; this is coded using the Polity IV methodology, as explained in the text. We have not coded constraint on the executive for Asia.

Atlantic Coast-to-Area includes those parts of Germany, Denmark and Norway that are on the North Sea. Average population in Atlantic ports is the percent of population living in Atlantic ports in our balanced panel dataset on average from 1300 to 1850 . For more detailed definitions and sources see Appendix Table 1. 
Table 2

Atlantic Trade and Urbanization

\begin{tabular}{|c|c|c|c|c|c|c|c|c|c|c|c|}
\hline & \multicolumn{11}{|c|}{ Dependent variable is country-level urbanization } \\
\hline & $\begin{array}{l}\text { Panel, } 1300-1850 \\
\quad(1) \\
\end{array}$ & $\begin{array}{l}\text { Panel, } 1000-1850 \\
\text { (2) }\end{array}$ & $\begin{array}{l}\text { Panel, } 1300- \\
1850 \\
(3)\end{array}$ & $\begin{array}{l}\text { Panel, } 1000- \\
1850 \\
(4)\end{array}$ & $\begin{array}{c}\text { Panel, 1300- } \\
1850, \\
\text { unweighted } \\
(5)\end{array}$ & $\begin{array}{l}\text { Panel, 1300- } \\
\text { 1850, with Asia } \\
(6)\end{array}$ & $\begin{array}{c}\text { Panel, } 1300- \\
\text { 1850, without } \\
\text { Britain } \\
(7) \\
\end{array}$ & $\begin{array}{l}\text { Panel, 1300- } \\
1850 \\
(8) \\
\end{array}$ & $\begin{array}{l}\text { Panel, 1000- } \\
1850 \\
(9) \\
\end{array}$ & $\begin{array}{c}\text { Panel, 1300- } \\
1850 \\
\text { unweighted } \\
(10)\end{array}$ & $\begin{array}{l}\text { Panel, 1300- } \\
\quad 1850 \\
(11) \\
\end{array}$ \\
\hline & & & \multicolumn{9}{|c|}{ Atlantic Trade is measured by: } \\
\hline & & & \multicolumn{5}{|c|}{ Atlantic trader dummy } & \multicolumn{3}{|c|}{ Atlantic coastline-to- land area } & $\begin{array}{c}\text { Average pop. in } \\
\text { Atlantic ports }\end{array}$ \\
\hline & & & & & Danel $A: f l$ & exible specif & ication & & & & \\
\hline $\begin{array}{l}\text { p-value for Western Europe } x \\
\text { year dummies, } 1600-1850\end{array}$ & {$[0.00]$} & {$[0.00]$} & {$[0.45]$} & {$[0.10]$} & {$[0.80]$} & {$[0.00]$} & {$[0.12]$} & {$[0.09]$} & {$[0.01]$} & {$[0.78]$} & {$[0.15]$} \\
\hline Atlantic Trade x 1500 & & & $\begin{array}{l}0.016 \\
(0.021)\end{array}$ & $\begin{array}{l}0.0086 \\
(0.019)\end{array}$ & $\begin{array}{l}0.055 \\
(0.026)\end{array}$ & $\begin{array}{l}0.014 \\
(0.022)\end{array}$ & $\begin{array}{l}0.018 \\
(0.016)\end{array}$ & $\begin{array}{l}0.50 \\
(0.68)\end{array}$ & $\begin{array}{l}0.38 \\
(0.65)\end{array}$ & $\begin{array}{l}0.75 \\
(0.87)\end{array}$ & $\begin{array}{l}0.57 \\
(0.45)\end{array}$ \\
\hline Atlantic Trade x 1600 & & & $\begin{array}{l}0.006 \\
(0.023)\end{array}$ & $\begin{array}{l}-0.004 \\
(0.021)\end{array}$ & $\begin{array}{l}0.0495 \\
(0.028)\end{array}$ & $\begin{array}{l}0.0054 \\
(0.028)\end{array}$ & $\begin{array}{l}0.0085 \\
(0.018)\end{array}$ & $\begin{array}{l}0.21 \\
(0.68)\end{array}$ & $\begin{array}{c}0.03 \\
(0.64)\end{array}$ & $\begin{array}{l}0.94 \\
(0.94)\end{array}$ & $\begin{array}{l}0.25 \\
(0.45)\end{array}$ \\
\hline Atlantic Trade x 1700 & & & $\begin{array}{l}0.032 \\
(0.021)\end{array}$ & $\begin{array}{l}0.022 \\
(0.019)\end{array}$ & $\begin{array}{l}0.071 \\
(0.028)\end{array}$ & $\begin{array}{l}0.032 \\
(0.026)\end{array}$ & $\begin{array}{l}0.024 \\
(0.016)\end{array}$ & $\begin{array}{l}1.81 \\
(0.63)\end{array}$ & $\begin{array}{l}1.64 \\
(0.58)\end{array}$ & $\begin{array}{l}2.01 \\
(0.94)\end{array}$ & $\begin{array}{l}1.20 \\
(0.39)\end{array}$ \\
\hline Atlantic Trade x 1750 & & & $\begin{array}{l}0.032 \\
(0.021)\end{array}$ & $\begin{array}{l}0.022 \\
(0.018)\end{array}$ & $\begin{array}{l}0.073 \\
(0.028)\end{array}$ & $\begin{array}{l}0.032 \\
(0.025)\end{array}$ & $\begin{array}{l}0.023 \\
(0.015)\end{array}$ & $\begin{array}{l}2.16 \\
(0.62)\end{array}$ & $\begin{array}{l}1.99 \\
(0.57)\end{array}$ & $\begin{array}{l}2.60 \\
(0.94)\end{array}$ & $\begin{array}{l}1.20 \\
(0.38)\end{array}$ \\
\hline Atlantic Trade x 1800 & & & $\begin{array}{l}0.048 \\
(0.019)\end{array}$ & $\begin{array}{l}0.038 \\
(0.017)\end{array}$ & $\begin{array}{l}0.110 \\
(0.028)\end{array}$ & $\begin{array}{l}0.047 \\
(0.023)\end{array}$ & $\begin{array}{l}0.028 \\
(0.015)\end{array}$ & $\begin{array}{l}3.30 \\
(0.57)\end{array}$ & $\begin{array}{l}3.12 \\
(0.51)\end{array}$ & $\begin{array}{l}3.76 \\
(0.94)\end{array}$ & $\begin{array}{l}1.70 \\
(0.35)\end{array}$ \\
\hline Atlantic Trade x 1850 & & & $\begin{array}{l}0.085 \\
(0.018)\end{array}$ & $\begin{array}{l}0.076 \\
(0.016)\end{array}$ & $\begin{array}{l}0.115 \\
(0.028)\end{array}$ & $\begin{array}{l}0.084 \\
(0.022)\end{array}$ & $\begin{array}{l}0.043 \\
(0.014)\end{array}$ & $\begin{array}{l}5.05 \\
(0.51)\end{array}$ & $\begin{array}{l}4.88 \\
(0.44)\end{array}$ & $\begin{array}{l}4.67 \\
(0.94)\end{array}$ & $\begin{array}{l}2.50 \\
(0.33)\end{array}$ \\
\hline R-Squared & 0.87 & 0.85 & 0.89 & 0.87 & 0.82 & 0.84 & 0.93 & 0.94 & 0.92 & 0.83 & 0.92 \\
\hline Number of Observations & 192 & 240 & 192 & 240 & 192 & 208 & 184 & 192 & 240 & 192 & 192 \\
\hline $\begin{array}{l}\text { p-value for Western Europe } \mathrm{x} \\
\text { year dummies, } 1600-1850\end{array}$ & {$[0.00]$} & {$[0.00]$} & {$[0.35]$} & {$[0.06]$} & $\begin{array}{l}\text { nel B: stru } \\
\text { [0.83] }\end{array}$ & $\begin{array}{l}\text { ictured spec } \\
{[0.00]}\end{array}$ & $\begin{array}{r}\text { ification } \\
{[0.11]}\end{array}$ & {$[0.16]$} & {$[0.02]$} & {$[0.81]$} & {$[0.15]$} \\
\hline $\begin{array}{l}\text { Atlantic Trade } \mathrm{x} \\
\text { Volume of Aggregate Atlantic Trade }\end{array}$ & & & $\begin{array}{l}0.011 \\
(0.0024)\end{array}$ & $\begin{array}{l}0.0083 \\
(0.0020)\end{array}$ & $\begin{array}{l}0.016 \\
(0.0034)\end{array}$ & $\begin{array}{l}0.011 \\
(0.0029)\end{array}$ & $\begin{array}{l}0.005 \\
(0.0018)\end{array}$ & $\begin{array}{l}0.75 \\
(0.07)\end{array}$ & $\begin{array}{l}0.65 \\
(0.06)\end{array}$ & $\begin{array}{l}0.62 \\
(0.11)\end{array}$ & $\begin{array}{l}0.37 \\
(0.04)\end{array}$ \\
\hline R-Squared & 0.87 & 0.85 & 0.88 & 0.86 & 0.81 & 0.84 & 0.92 & 0.92 & 0.90 & 0.82 & 0.92 \\
\hline Number of Observations & 192 & 240 & 192 & 240 & 192 & 208 & 184 & 192 & 240 & 192 & 192 \\
\hline
\end{tabular}

Standard errors are in parentheses. Panel regressions with full set of country and year dummies; regressions are weighted unless otherwise stated. Weighted regressions use total population in each year as weights, from McEvedy and Jones. Dependent variable is level of urbanization (percent of population living in towns which had at least 5,000 population at some point between 800 and 1800) in each country in each year. Urbanization in Europe is from Bairoch, Batou and Chèvre, and urbanization in Asia is from Bairoch. We report results with three different measures of Atlantic trade: a dummy for whether a country was an Atlantic trader (one for Britain, the Netherlands, France, Spain and Portugal; zero for all others) in columns 3, 4, 5, 6 and 7; the ratio of Atlantic coastline to land area, defining the Atlantic broadly to include Belgium, Denmark, Germany, Ireland, and Norway (columns 8, 9, and 10); the average percentage population in Atlantic ports during 1300-1850 is multiplied by 100 (column 11). Column 6 includes the available data on Asia (just for India and China) and column 7 drops the data for Britain. Total Atlantic Trade is the log average number of voyages per year. For more detailed data definitions and sources see Appendix Table 1. 
Table 3

Atlantic Trade and GDP per capita

\begin{tabular}{|c|c|c|c|c|c|c|c|c|c|c|c|}
\hline & \multicolumn{11}{|c|}{ Dependent Variable is country-level log GDP per capita } \\
\hline & $\begin{array}{l}\text { Panel, } 1500-1820 \\
\quad(1)\end{array}$ & $\begin{array}{l}\text { Panel, } 1500-1870 \\
(2)\end{array}$ & $\begin{array}{c}\text { Panel, } 1500- \\
1820 \\
(3) \\
\end{array}$ & $\begin{array}{c}\text { Panel, 1500- } \\
1870 \\
(4)\end{array}$ & $\begin{array}{c}\text { Panel, 1500- } \\
1820 \\
\text { unweighted } \\
(5)\end{array}$ & $\begin{array}{l}\text { Panel, 1500- } \\
\text { 1820, with Asia } \\
(6)\end{array}$ & $\begin{array}{c}\text { Panel, 1500- } \\
\text { 1820, without } \\
\text { Britain } \\
(7)\end{array}$ & $\begin{array}{c}\text { Panel, } 1500- \\
1820 \\
(8) \\
\end{array}$ & $\begin{array}{c}\text { Panel, } 1500- \\
1870 \\
(9) \\
\end{array}$ & $\begin{array}{c}\text { Panel, 1500- } \\
1820, \\
\text { unweighted } \\
(10)\end{array}$ & $\begin{array}{c}\text { Panel, 1500- } \\
1820 \\
(11) \\
\end{array}$ \\
\hline & & & \multicolumn{9}{|c|}{ Atlantic Trade is measured by: } \\
\hline & & & \multicolumn{5}{|c|}{ Atlantic trader dummy } & \multicolumn{3}{|c|}{ Atlantic coastline-to- land area } & $\begin{array}{l}\text { Average pop. in } \\
\text { Atlantic ports }\end{array}$ \\
\hline & & & & & anel $A: f l$ & exible speci & ication & & & & \\
\hline $\begin{array}{l}\text { p-value for Western Europe } \mathrm{x} \\
\text { year dummies, } 1600-1820 \text { or }-1870\end{array}$ & {$[0.44]$} & {$[0.05]$} & {$[0.92]$} & {$[0.23]$} & {$[0.17]$} & {$[0.01]$} & {$[0.89]$} & {$[0.97]$} & {$[0.58]$} & {$[0.31]$} & {$[0.96]$} \\
\hline Atlantic Trade x 1600 & & & $\begin{array}{l}0.14 \\
(0.07)\end{array}$ & $\begin{array}{l}0.15 \\
(0.11)\end{array}$ & $\begin{array}{l}0.16 \\
(0.07)\end{array}$ & $\begin{array}{l}0.14 \\
(0.13)\end{array}$ & $\begin{array}{l}0.13 \\
(0.07)\end{array}$ & $\begin{array}{l}4.43 \\
(2.42)\end{array}$ & $\begin{array}{c}4.46 \\
(3.61)\end{array}$ & $\begin{array}{l}3.42 \\
(2.21)\end{array}$ & $\begin{array}{l}3.00 \\
(1.30)\end{array}$ \\
\hline Atlantic Trade x 1700 & & & $\begin{array}{l}0.18 \\
(0.07)\end{array}$ & $\begin{array}{l}0.19 \\
(0.10)\end{array}$ & $\begin{array}{l}0.21 \\
(0.07)\end{array}$ & $\begin{array}{l}0.18 \\
(0.12)\end{array}$ & $\begin{array}{l}0.14 \\
(0.06)\end{array}$ & $\begin{array}{l}8.84 \\
(2.27)\end{array}$ & $\begin{array}{l}8.80 \\
(3.40)\end{array}$ & $\begin{array}{l}6.32 \\
(2.21)\end{array}$ & $\begin{array}{l}5.40 \\
(1.30)\end{array}$ \\
\hline Atlantic Trade x 1820 & & & $\begin{array}{l}0.27 \\
(0.06)\end{array}$ & $\begin{array}{l}0.27 \\
(0.10)\end{array}$ & $\begin{array}{l}0.18 \\
(0.07)\end{array}$ & $\begin{array}{l}0.27 \\
(0.11)\end{array}$ & $\begin{array}{l}0.20 \\
(0.06)\end{array}$ & $\begin{array}{l}12.03 \\
(2.10)\end{array}$ & $\begin{array}{l}11.89 \\
(3.14)\end{array}$ & $\begin{array}{l}8.06 \\
(2.21)\end{array}$ & $\begin{array}{l}6.20 \\
(1.10)\end{array}$ \\
\hline Atlantic Trade x 1870 & & & & $\begin{array}{l}0.22 \\
(0.09)\end{array}$ & & & & & $\begin{array}{l}15.84 \\
(2.93)\end{array}$ & & \\
\hline R-Squared & 0.94 & 0.94 & 0.96 & 0.95 & 0.96 & 0.92 & 0.96 & 0.96 & 0.96 & 0.96 & 0.96 \\
\hline Number of Observations & 96 & 120 & 96 & 120 & 96 & 104 & 92 & 96 & 120 & 96 & 96 \\
\hline $\begin{array}{l}\text { p-value for Western Europe } \mathrm{x} \\
\text { year dummies, } 1600-1850\end{array}$ & {$[0.44]$} & {$[0.05]$} & {$[0.92]$} & {$[0.48]$} & $\begin{array}{l}\text { inel B: str } \\
{[0.14]}\end{array}$ & $\begin{array}{l}\text { uctured spec } \\
\quad[0.01]\end{array}$ & $\begin{array}{r}\text { ification } \\
{[0.88]}\end{array}$ & {$[0.99]$} & {$[0.54]$} & {$[0.23]$} & {$[0.93]$} \\
\hline $\begin{array}{l}\text { Atlantic Trade } \mathrm{x} \\
\text { Volume of Aggregate Atlantic Trade }\end{array}$ & & & $\begin{array}{l}0.069 \\
(0.016)\end{array}$ & $\begin{array}{l}0.040 \\
(0.017)\end{array}$ & $\begin{array}{l}0.047 \\
(0.018)\end{array}$ & $\begin{array}{c}0.069 \\
(0.028)\end{array}$ & $\begin{array}{l}0.051 \\
(0.015)\end{array}$ & $\begin{array}{c}3.21 \\
(0.53)\end{array}$ & $\begin{array}{l}3.18 \\
(0.50)\end{array}$ & $\begin{array}{l}2.22 \\
(0.58)\end{array}$ & $\begin{array}{l}1.58 \\
(0.31)\end{array}$ \\
\hline R-Squared & 0.94 & 0.94 & 0.96 & 0.95 & 0.96 & 0.92 & 0.96 & 0.96 & 0.96 & 0.96 & 0.96 \\
\hline Number of Observations & 96 & 120 & 96 & 120 & 96 & 104 & 92 & 96 & 120 & 96 & 96 \\
\hline
\end{tabular}

Standard errors are in parentheses. Panel regressions with full set of country and year dummies; regressions are weighted unless otherwise stated. Weighted regressions use total population in each year as weights, from McEvedy and Jones. Dependent variable is log GDP per capita, from Maddison. We report results with three different measures of Atlantic trade: a dummy for whether a country was an Atlantic trader (one for Britain, the Netherlands, France, Spain and Portugal; zero for all others) in columns 3, 4, 5, 6 and 7; the ratio of Atlantic coastline to land area, defining the Atlantic broadly to include Belgium, Denmark, Germany, Ireland, and Norway (columns 8, 9, and 10); the average percentage population in Atlantic ports during 1300-1850, multiplied by 100 (column 11). Column 6 includes the available data on Asia (just for India and China) and column 7 drops the data for Britain. Total Atlantic Trade is the log average number of voyages per year. For more detailed data definitions and sources see Appendix Table 1. 


\begin{tabular}{|c|c|c|c|c|c|c|c|c|}
\hline & $\begin{array}{l}\text { Panel, } 1300-1850, \\
\text { controlling for } \\
\text { religion } \\
\text { (1) }\end{array}$ & $\begin{array}{l}\text { Panel, } 1300 \text { to } \\
1850 \\
\text { controlling for } \\
\text { wars } \\
\text { (2) }\end{array}$ & $\begin{array}{l}1850, \\
\text { controlling for } \\
\text { Roman } \\
\text { heritage } \\
\text { (3) }\end{array}$ & $\begin{array}{l}\text { Panel, } 1300 \text { to } \\
1850 \text {, } \\
\text { controlling for } \\
\text { latitude } \\
\text { (4) }\end{array}$ & $\begin{array}{l}\text { Panel, 1500-1820, } \\
\text { controlling for } \\
\text { religion } \\
\text { (5) }\end{array}$ & $\begin{array}{l}\text { Panel, } 1500 \text { to } \\
1820 \text {, } \\
\text { controlling for } \\
\text { wars } \\
(6)\end{array}$ & $\begin{array}{l}\text { Panel, } 1500 \text { to } 1820, \\
\text { controlling for } \\
\text { Roman heritage } \\
\text { (7) }\end{array}$ & $\begin{array}{l}\text { Panel, } 1500 \text { to } \\
1820 \text {, controlling } \\
\text { for latitude } \\
\text { (8) }\end{array}$ \\
\hline & \multicolumn{8}{|c|}{ Using Atlantic trader dummy measure of Atlantic Trade } \\
\hline & \multicolumn{4}{|c|}{$\begin{array}{c}\text { Panel A: Dependent Variable is Level of } \\
\text { Urbanization }\end{array}$} & \multicolumn{4}{|c|}{ Panel B: Dependent Variable is Log GDP per capita } \\
\hline $\begin{array}{l}\text { p-value for Western Europe x } \\
\text { year dummies, } 1600-1850\end{array}$ & {$[0.73]$} & {$[0.49]$} & {$[0.49]$} & {$[0.09]$} & {$[0.24]$} & {$[0.91]$} & {$[0.15]$} & {$[0.85]$} \\
\hline $\begin{array}{l}\text { Atlantic Trader Dummy x } \\
\text { Volume of Aggregate Atlantic Trade }\end{array}$ & $\begin{array}{l}0.013 \\
(0.002)\end{array}$ & $\begin{array}{l}0.011 \\
(0.003)\end{array}$ & $\begin{array}{l}0.011 \\
(0.003)\end{array}$ & $\begin{array}{l}0.011 \\
(0.002)\end{array}$ & $\begin{array}{l}0.089 \\
(0.013)\end{array}$ & $\begin{array}{l}0.070 \\
(0.017)\end{array}$ & $\begin{array}{l}0.125 \\
(0.017)\end{array}$ & $\begin{array}{l}0.078 \\
(0.015)\end{array}$ \\
\hline $\mathrm{p}$-value for Protestant $\mathrm{x}$ Year & {$[0.05]$} & & & & {$[0.00]$} & & & \\
\hline Wars per year in preceding century & & $\begin{array}{r}-0.0006 \\
(0.008)\end{array}$ & & & & $\begin{array}{c}0.075 \\
(0.029)\end{array}$ & & \\
\hline p-value for Roman Heritage $\mathrm{x}$ Year & & & {$[0.89]$} & & & & {$[0.00]$} & \\
\hline p-value for Latitude x Year & & & & {$[0.11]$} & & & & {$[0.00]$} \\
\hline R-Squared & 0.89 & 0.89 & 0.89 & 0.89 & 0.97 & 0.95 & 0.97 & 0.97 \\
\hline \multirow[t]{3}{*}{ Number of Observations } & 192 & 176 & 192 & 192 & 96 & 88 & 96 & 96 \\
\hline & \multicolumn{8}{|c|}{ Using coastline-to-area measure of Atlantic Trade } \\
\hline & \multicolumn{4}{|c|}{$\begin{array}{c}\text { Panel C: Dependent Variable is Level of } \\
\text { Urbanization }\end{array}$} & \multicolumn{4}{|c|}{ Panel D: Dependent Variable is Log GDP per capita } \\
\hline $\begin{array}{l}\text { p-value for Western Europe x } \\
\text { year dummies, } 1600-1850\end{array}$ & {$[0.19]$} & {$[0.26]$} & {$[0.39]$} & {$[0.09]$} & {$[0.99]$} & {$[0.98]$} & {$[0.71]$} & {$[0.81]$} \\
\hline $\begin{array}{l}\text { Coastline-to-area x } \\
\text { Volume of Aggregate Atlantic Trade }\end{array}$ & $\begin{array}{l}0.79 \\
(0.08)\end{array}$ & $\begin{array}{l}0.76 \\
(0.08)\end{array}$ & $\begin{array}{l}0.75 \\
(0.07)\end{array}$ & $\begin{array}{l}0.78 \\
(0.07)\end{array}$ & $\begin{array}{l}2.78 \\
(0.54)\end{array}$ & $\begin{array}{l}3.33 \\
(0.56)\end{array}$ & $\begin{array}{l}3.32 \\
(0.54)\end{array}$ & $\begin{array}{l}2.96 \\
(0.56)\end{array}$ \\
\hline $\mathrm{p}$-value for Protestant $\mathrm{x}$ Year & {$[0.51]$} & & & & {$[0.05]$} & & & \\
\hline Wars per year in preceding century & & $\begin{array}{l}0.0082 \\
(0.007)\end{array}$ & & & & $\begin{array}{c}0.032 \\
(0.026)\end{array}$ & & \\
\hline p-value for Roman Heritage x Year & & & {$[0.77]$} & & & & {$[0.32]$} & \\
\hline p-value for Latitude x Year & & & & {$[0.52]$} & & & & {$[0.38]$} \\
\hline R-Squared & 0.93 & 0.93 & 0.92 & 0.93 & 0.97 & 0.96 & 0.97 & 0.97 \\
\hline Number of Observations & 192 & 176 & 192 & 192 & 96 & 88 & 96 & 96 \\
\hline
\end{tabular}

Standard errors are in parentheses. Weighted panel regressions with full set of country and year dummies. Weights are total population of country in each year from McEvedy and Jones. Dependent variable in Panels A and C is level of urbanization (percent of population living in towns with more than 5,000 population.) Urbanization in Europe is from Bairoch, Batou and Chèvre, and urbanization in Asia is from Bairoch. Dependent variable in Panels B and D is log GDP per capita, from Maddison. Panels A and B use the Atlantic trader dummy as the measure of Atlantic trade (one for Britain, France, Spain, Portugal and the Netherlands, zero for all others). Panels C and $\mathrm{D}$ use the ratio of Atlantic coastline to land area. Total Atlantic Trade is the log average number of voyages per year. Protestant is a dummy for whether country was majority Protestant in 1600. Protestant $x$ Year is the Protestant dummy interacted with year dummies for 1600 and after. Wars per year are in preceding century through 1700, 1700-1750 for 1750, 1750-1800 for 1800 and $1800-1850$ for 1850.

Roman heritage is dummy for whether country was in Roman empire and not subsequently in Ottoman empire; this is interacted with year dummies for 1600 and after. Latitude is distance from the equator for capital city of this country today; this is interacted with year dummies for 1600 and after. For more detailed data definitions and sources see Appendix Table 1. 
Table 5

Growth of Atlantic Ports: Balanced Panel

\section{Dependent Variable is log city population}

Balanced Panel,

Balanced Panel,

Balanced Panel

300-1850, weighted, 1300-1850, weighted, Balanced Panel, 1300-1850; with

Balanced Panel, Balanced Panel, Balanced Panel, 1300Balanced Panel, $\quad 1300-1850, \quad 1300-1850, \quad 1300-1850, \quad$ without London and with full set of country 1300-1850, with Mediterranean 1300-1850, weighted unweighted weighted unweighted Amsterdam x year interactions Asia and Atlantic ports

\begin{tabular}{|c|c|c|c|c|c|c|c|c|}
\hline \multirow[b]{4}{*}{$\begin{array}{l}\text { p-value for Western Europe } x \\
\text { year dummies, } 1600-1850\end{array}$} & $(1)$ & $(2)$ & $(3)$ & (4) & $(5)$ & $(6)$ & $(7)$ & $(8)$ \\
\hline & \multicolumn{8}{|c|}{ Panel A: flexible specification } \\
\hline & \multicolumn{2}{|c|}{ Atlantic port } & \multicolumn{2}{|c|}{ Potential Atlantic port } & \multicolumn{4}{|c|}{ Atlantic port } \\
\hline & {$[0.34]$} & {$[0.05]$} & {$[0.30]$} & {$[0.16]$} & {$[0.28]$} & {$[0.30]$} & {$[0.41]$} & {$[0.32]$} \\
\hline Atlantic port x 1500 & $\begin{array}{l}-0.04 \\
(0.19)\end{array}$ & $\begin{array}{l}-0.05 \\
(0.20)\end{array}$ & $\begin{array}{l}0.027 \\
(0.17)\end{array}$ & $\begin{array}{l}0.048 \\
(0.16)\end{array}$ & $\begin{array}{l}-0.008 \\
(0.20)\end{array}$ & $\begin{array}{l}-0.072 \\
(0.20)\end{array}$ & $\begin{array}{l}-0.03 \\
(0.20)\end{array}$ & $\begin{array}{l}-0.05 \\
(0.19)\end{array}$ \\
\hline Atlantic port x 1600 & $\begin{array}{l}0.36 \\
(0.16)\end{array}$ & $\begin{array}{c}0.46 \\
(0.20)\end{array}$ & $\begin{array}{c}0.41 \\
(0.14)\end{array}$ & $\begin{array}{c}0.43 \\
(0.16)\end{array}$ & $\begin{array}{c}0.41 \\
(0.17)\end{array}$ & $\begin{array}{c}0.36 \\
(0.17)\end{array}$ & $\begin{array}{c}0.36 \\
(0.16)\end{array}$ & $\begin{array}{l}0.40 \\
(0.16)\end{array}$ \\
\hline Atlantic port x 1700 & $\begin{array}{l}0.71 \\
(0.14)\end{array}$ & $\begin{array}{c}0.62 \\
(0.20)\end{array}$ & $\begin{array}{c}0.76 \\
(0.13)\end{array}$ & $\begin{array}{c}0.76 \\
(0.16)\end{array}$ & $\begin{array}{l}0.297 \\
(0.17)\end{array}$ & $\begin{array}{c}0.47 \\
(0.17)\end{array}$ & $\begin{array}{c}0.71 \\
(0.15)\end{array}$ & $\begin{array}{l}0.74 \\
(0.15)\end{array}$ \\
\hline Atlantic port x 1750 & $\begin{array}{l}0.70 \\
(0.14)\end{array}$ & $\begin{array}{c}0.71 \\
(0.20)\end{array}$ & $\begin{array}{c}0.79 \\
(0.13)\end{array}$ & $\begin{array}{c}0.89 \\
(0.16)\end{array}$ & $\begin{array}{l}0.26 \\
(0.16)\end{array}$ & $\begin{array}{l}0.46 \\
(0.16)\end{array}$ & $\begin{array}{c}0.7 \\
(0.15)\end{array}$ & $\begin{array}{l}0.72 \\
(0.14)\end{array}$ \\
\hline Atlantic port x 1800 & $\begin{array}{l}0.79 \\
(0.14)\end{array}$ & $\begin{array}{c}0.92 \\
(0.20)\end{array}$ & $\begin{array}{c}0.95 \\
(0.12)\end{array}$ & $\begin{array}{c}1.10 \\
(0.16)\end{array}$ & $\begin{array}{c}0.32 \\
(0.15)\end{array}$ & $\begin{array}{c}0.57 \\
(0.15)\end{array}$ & $\begin{array}{l}0.799 \\
(0.14)\end{array}$ & $\begin{array}{l}0.84 \\
(0.14)\end{array}$ \\
\hline Atlantic port x 1850 & $\begin{array}{l}1.09 \\
(0.13)\end{array}$ & $\begin{array}{c}1.00 \\
(0.20)\end{array}$ & $\begin{array}{l}1.19 \\
(0.12)\end{array}$ & $\begin{array}{l}1.23 \\
(0.16)\end{array}$ & $\begin{array}{l}0.48 \\
(0.14)\end{array}$ & $\begin{array}{l}0.46 \\
(0.14)\end{array}$ & $\begin{array}{c}1.09 \\
(0.14)\end{array}$ & $\begin{array}{l}1.10 \\
(0.13)\end{array}$ \\
\hline $\begin{array}{l}\text { p-value for Mediterranean port } x \\
\text { year dummies, } 1500-1850\end{array}$ & & & & & & & & {$[0.19]$} \\
\hline R-Squared & 0.92 & 0.79 & 0.92 & 0.80 & 0.89 & 0.95 & 0.94 & 0.92 \\
\hline Number of Observations & 1544 & 1544 & 1544 & 1544 & 1528 & 1544 & 1624 & 1544 \\
\hline $\begin{array}{l}\text { p-value for Western Europe } \mathrm{x} \\
\text { year dummies, } 1600-1850\end{array}$ & {$[0.23]$} & {$[0.04]$} & {$[0.23]$} & $\begin{array}{l}\text { Panel B: s } \\
\quad[0.10]\end{array}$ & $\begin{array}{c}\text { pecificat } \\
{[0.31]}\end{array}$ & {$[0.33]$} & {$[0.20]$} & {$[0.20]$} \\
\hline $\begin{array}{l}\text { Volume of Aggregate Atlantic Trade } \\
\text { x Atlantic Ports }\end{array}$ & $\begin{array}{l}0.17 \\
(0.02)\end{array}$ & $\begin{array}{l}0.16 \\
(0.02)\end{array}$ & $\begin{array}{c}0.17 \\
(0.017)\end{array}$ & $\begin{array}{c}0.16 \\
(0.024)\end{array}$ & $\begin{array}{c}0.065 \\
(0.019)\end{array}$ & $\begin{array}{c}0.078 \\
(0.018)\end{array}$ & $\begin{array}{l}0.27 \\
(0.017)\end{array}$ & $\begin{array}{l}0.17 \\
(0.017)\end{array}$ \\
\hline $\begin{array}{l}\text { p-value for Mediterranean port } \mathrm{x} \\
\text { year dummies, } 1500-1850\end{array}$ & & & & & & & & {$[0.14]$} \\
\hline $\begin{array}{l}\text { R-Squared } \\
\text { Number of Observations }\end{array}$ & $\begin{array}{r}0.92 \\
1544\end{array}$ & $\begin{array}{l}0.79 \\
1544\end{array}$ & $\begin{array}{c}0.92 \\
1544\end{array}$ & $\begin{array}{l}0.79 \\
1544\end{array}$ & $\begin{array}{l}0.89 \\
1528\end{array}$ & $\begin{array}{l}0.95 \\
1544\end{array}$ & $\begin{array}{r}0.88 \\
1624\end{array}$ & $\begin{array}{r}0.92 \\
1544\end{array}$ \\
\hline
\end{tabular}

Standard errors are in parentheses. Weighted panel regressions with full set of city and year dummies; weights are level of population in each year for each city during the sample period.

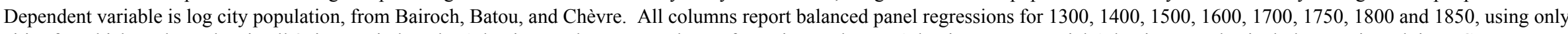

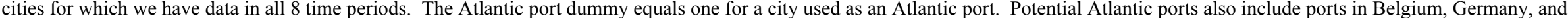

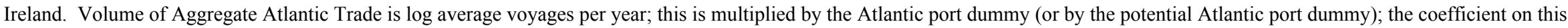

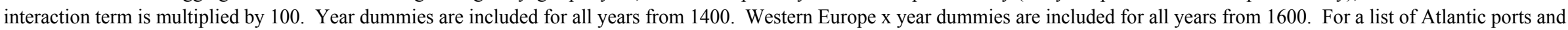
potential Atlantic ports, see the Appendix. 
Table 6

Robustness Checks for Growth of Atlantic Ports

Dependent Variable is log city population

\begin{tabular}{|c|c|c|c|c|c|c|c|c|}
\hline \multicolumn{9}{|c|}{ Dependent Variable is log city population } \\
\hline & $\begin{array}{l}\text { Balanced Panel, } 1300- \\
\text { 1850; controlling for } \\
\text { religion } \\
(1)\end{array}$ & $\begin{array}{l}\text { Balanced Panel, 1300- } \\
\text { 1850; controlling for } \\
\text { religion } \\
(2) \\
\end{array}$ & $\begin{array}{l}\text { Balanced Panel, } \\
\text { 1300-1850; } \\
\text { controlling for war } \\
\text { (3) }\end{array}$ & $\begin{array}{l}\text { Balanced Panel, } \\
\text { 1300-1850; } \\
\text { controlling for war } \\
\text { (4) }\end{array}$ & $\begin{array}{l}\text { Balanced Panel, } \\
\text { 1300-1850; } \\
\text { controlling for } \\
\text { Roman heritage } \\
\quad(5)\end{array}$ & $\begin{array}{l}\text { Balanced Panel, } \\
\text { 1300-1850; } \\
\text { controlling for } \\
\text { Roman heritage } \\
(6)\end{array}$ & $\begin{array}{l}\text { Balanced Panel, } \\
\text { 1400-1850; } \\
\text { controlling for } \\
\text { latitude } \\
\text { (7) }\end{array}$ & $\begin{array}{l}\text { Balanced Panel, } \\
\text { 1400-1850; } \\
\text { controlling for } \\
\text { latitude } \\
(8) \\
\end{array}$ \\
\hline $\begin{array}{l}\text { p-value for Western Europe } x \\
\text { year dummies, } 1600-1850\end{array}$ & {$[0.26]$} & {$[0.17]$} & {$[0.11]$} & {$[0.09]$} & [0.009] & {$[0.00]$} & {$[0.01]$} & {$[0.00]$} \\
\hline Atlantic port x 1500 & $\begin{array}{l}-0.04 \\
(0.18)\end{array}$ & & $\begin{array}{l}-0.04 \\
(0.19)\end{array}$ & & $\begin{array}{r}-0.004 \\
(0.19)\end{array}$ & & $\begin{array}{c}0.0008 \\
(0.18)\end{array}$ & \\
\hline Atlantic port x 1600 & $\begin{array}{c}0.41 \\
(0.15)\end{array}$ & & $\begin{array}{l}0.35 \\
(0.15)\end{array}$ & & $\begin{array}{l}0.37 \\
(0.15)\end{array}$ & & $\begin{array}{c}0.44 \\
(0.15)\end{array}$ & \\
\hline Atlantic port x 1700 & $\begin{array}{l}0.72 \\
(0.15)\end{array}$ & & $\begin{array}{l}0.66 \\
(0.14)\end{array}$ & & $\begin{array}{l}0.72 \\
(0.14)\end{array}$ & & $\begin{array}{c}0.81 \\
(0.14)\end{array}$ & \\
\hline Atlantic port x 1750 & $\begin{array}{l}0.67 \\
(0.14)\end{array}$ & & $\begin{array}{l}0.71 \\
(0.14)\end{array}$ & & $\begin{array}{l}0.74 \\
(0.14)\end{array}$ & & $\begin{array}{c}0.8 \\
(0.13)\end{array}$ & \\
\hline Atlantic port x 1800 & $\begin{array}{l}0.73 \\
(0.14)\end{array}$ & & $\begin{array}{l}0.81 \\
(0.13)\end{array}$ & & $\begin{array}{l}0.88 \\
(0.14)\end{array}$ & & $\begin{array}{c}0.87 \\
(0.13)\end{array}$ & \\
\hline Atlantic port x 1850 & $\begin{array}{l}0.89 \\
(0.13)\end{array}$ & & $\begin{array}{l}1.11 \\
(0.13)\end{array}$ & & $\begin{array}{l}1.20 \\
(0.13)\end{array}$ & & $\begin{array}{l}1.09 \\
(0.12)\end{array}$ & \\
\hline $\begin{array}{l}\text { Volume of Aggregate Atlantic } \\
\text { x Atlantic Ports }\end{array}$ & Trade & $\begin{array}{l}0.13 \\
(0.02)\end{array}$ & & $\begin{array}{l}0.17 \\
(0.02)\end{array}$ & & $\begin{array}{l}0.18 \\
(0.02)\end{array}$ & & $\begin{array}{c}0.16 \\
(0.016)\end{array}$ \\
\hline p-value for Protestant x Year & {$[0.00]$} & {$[0.00]$} & & & & & & \\
\hline Average years of war & & & $\begin{array}{c}0.094 \\
(0.049)\end{array}$ & $\begin{array}{c}0.106 \\
(0.048)\end{array}$ & & & & \\
\hline p-value for Roman Heritage $x$ & Year & & & & {$[0.00]$} & {$[0.01]$} & & \\
\hline p-value for Latitude $x$ Year & & & & & & & {$[0.00]$} & {$[0.00]$} \\
\hline R-Squared & 0.93 & 0.93 & 0.92 & 0.92 & 0.92 & 0.92 & 0.93 & 0.93 \\
\hline Number of Observations & 1544 & 1544 & 1480 & 1480 & 1544 & 1544 & 1544 & 1544 \\
\hline
\end{tabular}

Standard errors are in parentheses. Weighted panel regressions with full set of city and year dummies; weights are level of population in each year for each city during the sample period. Dependent variable is log total urban population, from Bairoch, Batou, and Chèvre. All columns report balanced panel regressions for 1300, 1400, 1500, 1600, 1700, 1750, 1800 and 1850, using only cities for which we have data in all 8 time periods. The Atlantic port dummy equals one for a city used as an Atlantic port. Potential Atlantic ports also include ports in Belgium, Germany, and Ireland. Total Atlantic trade is log average voyages per year. Western Europe x year dummies are included for all years from 1600. For a list of Atlantic ports, see the appendix.

Protestant is a dummy for whether city was Protestant in 1600. Protestant x Year is the Protestant dummy interacted with year dummies for 1600 and after. Wars per year are in preceding century through 1700, 1700-1750 for 1750, 1750-1800 for 1800 and 1800-1850 for 1850. Roman heritage is dummy for whether the city was in Roman empire and not subsequently in Ottoman empire; this is interacted with year dummies for 1600 and after. Latitude is distance from the equator for this city; this is interacted with year dummies for 1600 and after. For more detailed data definitions and sources see Appendix Table 1. 
Table 7

Growth of Atlantic Ports: Unbalanced Panel

\begin{tabular}{|c|c|c|c|c|c|c|c|}
\hline & \multicolumn{7}{|c|}{ "Dependent Variable is log city population } \\
\hline & \multirow[t]{3}{*}{$\begin{array}{c}\text { Just European cities } \\
\text { (1) }\end{array}$} & $\begin{array}{l}\text { Just European cities } \\
\qquad(2)\end{array}$ & $\begin{array}{l}\text { Just European cities } \\
\text { (3) }\end{array}$ & $\begin{array}{c}\text { European cities in } \\
\text { balanced panel } \\
\text { (4) }\end{array}$ & $\begin{array}{c}\text { European cities in } \\
\text { balanced panel } \\
\text { (5) }\end{array}$ & $\begin{array}{l}\text { European and Asian } \\
\text { cities } \\
\text { (6) }\end{array}$ & $\begin{array}{l}\text { European and Asian } \\
\text { cities } \\
\text { (7) }\end{array}$ \\
\hline & & & Potential Atlantic & & & & \\
\hline & & Atlantic port & port & \multicolumn{4}{|c|}{ Atlantic port } \\
\hline & \multicolumn{7}{|c|}{ Panel A: 1300-1500 } \\
\hline 1500 dummy & $(0.09)$ & $(0.09)$ & $(0.09)$ & $(0.13)$ & $(0.13)$ & $(0.04)$ & $(0.04)$ \\
\hline \multirow[t]{2}{*}{ Western Europe in 1500} & -0.26 & -0.27 & -0.28 & -0.30 & -0.31 & -0.15 & -0.16 \\
\hline & $(0.10)$ & $(0.10)$ & $(0.10)$ & $(0.14)$ & $(0.14)$ & $(0.06)$ & $(0.06)$ \\
\hline \multirow[t]{2}{*}{ Atlantic port in 1500} & & 0.17 & 0.18 & & 0.09 & & 0.17 \\
\hline & & $(0.14)$ & $(0.12)$ & & $(0.16)$ & & $(0.15)$ \\
\hline R-Squared & 0.92 & 0.92 & 0.92 & 0.91 & 0.91 & 0.95 & 0.96 \\
\hline Number of Observations & \multicolumn{7}{|c|}{ Panel B: 1500-1700 } \\
\hline \multirow[t]{2}{*}{1700 dummy } & 0.25 & 0.25 & 0.25 & 0.22 & 0.22 & 0.22 & 0.22 \\
\hline & $(0.09)$ & $(0.08)$ & $(0.08)$ & $(0.15)$ & $(0.14)$ & $(0.04)$ & $(0.04)$ \\
\hline \multirow[t]{2}{*}{ Western Europe in 1700} & 0.13 & 0.06 & 0.03 & 0.24 & 0.15 & 0.16 & 0.08 \\
\hline & $(0.09)$ & $(0.09)$ & $(0.09)$ & $(0.16)$ & $(0.15)$ & $(0.06)$ & $(0.06)$ \\
\hline \multirow[t]{2}{*}{ Atlantic port in 1700} & & 0.77 & 0.76 & & 0.75 & & 0.77 \\
\hline & & $(0.11)$ & $(0.09)$ & & $(0.16)$ & & $(0.12)$ \\
\hline R-Squared & 0.94 & 0.95 & 0.95 & 0.87 & 0.94 & 0.96 & 0.96 \\
\hline \multirow[t]{2}{*}{ Number of Observations } & 1030 & 1030 & 1030 & 386 & 386 & 1086 & 1086 \\
\hline & \multicolumn{7}{|c|}{ Panel C: $1500-1800$} \\
\hline \multirow[t]{2}{*}{1800 dummy } & 0.45 & 0.45 & 0.45 & 0.54 & 0.55 & 0.46 & 0.46 \\
\hline & $(0.09)$ & $(0.09)$ & $(0.09)$ & $(0.18)$ & $(0.17)$ & $(0.05)$ & $(0.05)$ \\
\hline \multirow[t]{2}{*}{ Atlantic port in 1800} & & 0.82 & 0.90 & & 0.88 & & 0.82 \\
\hline & & $(0.12)$ & $(0.10)$ & & $(0.18)$ & & $(0.13)$ \\
\hline R-Squared & 0.94 & 0.95 & 0.95 & 0.93 & 0.94 & 0.96 & 0.96 \\
\hline Number of Observations & 1244 & 1244 & 1244 & 386 & 386 & 1300 & 1300 \\
\hline
\end{tabular}

Standard errors are in parentheses. Weighted panel regressions with full set of city and year dummies; weights are population in each year for each city during the sample period. Dependent variable is log total urban population, from Bairoch, Batou, and Chèvre. Panel A uses data only from 1300 and 1500 , Panel B uses data only from 1500 and 1700, and Panel C uses data only from 1500 and 1800. The Atlantic port dummy equals one for a city used as an Atlantic port. Potential Atlantic ports also include ports in Belgium, Germany, and Ireland. For a list of Atlantic ports, see the Appendix. 
Table 8

Growth of Non-Atlantic Urban Population

\begin{tabular}{|c|c|c|c|c|c|c|c|c|c|c|c|}
\hline & \multicolumn{11}{|c|}{ Dependent Variable is non-Atlantic urbanization } \\
\hline & $\begin{array}{l}\text { Panel, } 1300-1850 \\
\text { (1) }\end{array}$ & $\begin{array}{l}\text { Panel, } 1000-1850 \\
\text { (2) }\end{array}$ & $\begin{array}{c}\text { Panel, 1300- } \\
1850 \\
\text { (3) }\end{array}$ & $\begin{array}{c}\text { Panel, 1000- } \\
1850 \\
(4)\end{array}$ & $\begin{array}{c}\text { Panel, } 1300- \\
1850, \\
\text { unweighted } \\
(5)\end{array}$ & $\begin{array}{l}\text { Panel, } 1300- \\
\text { 1850, with Asia } \\
\text { (6) }\end{array}$ & $\begin{array}{c}\text { Panel, 1300- } \\
\text { 1850, without } \\
\text { Britain } \\
(7)\end{array}$ & $\begin{array}{c}\text { Panel, 1300- } \\
1850 \\
(8)\end{array}$ & $\begin{array}{c}\text { Panel, 1000- } \\
1850 \\
(9)\end{array}$ & $\begin{array}{c}\text { Panel, 1300- } \\
1850 \\
\text { unweighted } \\
(10)\end{array}$ & $\begin{array}{c}\text { Panel, 1300- } \\
1850 \\
(11)\end{array}$ \\
\hline & & & \multicolumn{9}{|c|}{ Atlantic Trade is measured by: } \\
\hline & & & \multicolumn{5}{|c|}{ Atlantic trader dummy } & \multicolumn{3}{|c|}{ Atlantic coastline-to- land area } & $\begin{array}{l}\text { Average pop. in } \\
\text { Atlantic ports }\end{array}$ \\
\hline & & & & & Panel $A: f$ & exible speci & fication & & & & \\
\hline $\begin{array}{l}\text { p-value for Western Europe } x \\
\text { year dummies, } 1600-1850\end{array}$ & {$[0.00]$} & {$[0.00]$} & {$[0.25]$} & {$[0.02]$} & {$[0.79]$} & {$[0.00]$} & {$[0.13]$} & {$[0.02]$} & {$[0.001]$} & {$[0.79]$} & {$[0.02]$} \\
\hline Atlantic Trade x 1500 & & & $\begin{array}{l}0.016 \\
(0.017)\end{array}$ & $\begin{array}{l}0.0044 \\
(0.015)\end{array}$ & $\begin{array}{c}0.051 \\
(0.024)\end{array}$ & $\begin{array}{c}0.014 \\
(0.019)\end{array}$ & $\begin{array}{l}0.016 \\
(0.016)\end{array}$ & $\begin{array}{c}0.54 \\
(0.66)\end{array}$ & $\begin{array}{l}0.21 \\
(0.62)\end{array}$ & $\begin{array}{l}0.78 \\
(0.84)\end{array}$ & $\begin{array}{l}0.53 \\
(0.40)\end{array}$ \\
\hline Atlantic Trade x 1600 & & & $\begin{array}{l}-0.003 \\
(0.018)\end{array}$ & $\begin{array}{l}-0.018 \\
(0.017)\end{array}$ & $\begin{array}{l}0.028 \\
(0.026)\end{array}$ & $\begin{array}{l}-0.004 \\
(0.025)\end{array}$ & $\begin{array}{l}0.001 \\
(0.017)\end{array}$ & $\begin{array}{l}-0.40 \\
(0.66)\end{array}$ & $\begin{array}{l}-0.76 \\
(0.62)\end{array}$ & $\begin{array}{l}0.48 \\
(0.91)\end{array}$ & $\begin{array}{l}-0.18 \\
(0.37)\end{array}$ \\
\hline Atlantic Trade x 1700 & & & $\begin{array}{l}0.016 \\
(0.017)\end{array}$ & $\begin{array}{l}0.002 \\
(0.016)\end{array}$ & $\begin{array}{l}0.026 \\
(0.026)\end{array}$ & $\begin{array}{l}0.015 \\
(0.023)\end{array}$ & $\begin{array}{l}0.018 \\
(0.016)\end{array}$ & $\begin{array}{l}0.06 \\
(0.61)\end{array}$ & $\begin{array}{l}-0.30 \\
(0.56)\end{array}$ & $\begin{array}{l}0.51 \\
(0.91)\end{array}$ & $\begin{array}{l}0.10 \\
(0.35)\end{array}$ \\
\hline Atlantic Trade x 1750 & & & $\begin{array}{l}0.014 \\
(0.016)\end{array}$ & $\begin{array}{l}-0.001 \\
(0.015)\end{array}$ & $\begin{array}{l}0.026 \\
(0.026)\end{array}$ & $\begin{array}{l}0.013 \\
(0.022)\end{array}$ & $\begin{array}{c}0.017 \\
(0.015)\end{array}$ & $\begin{array}{l}0.003 \\
(0.60)\end{array}$ & $\begin{array}{l}-0.36 \\
(0.55)\end{array}$ & $\begin{array}{l}0.68 \\
(0.91)\end{array}$ & $\begin{array}{l}-0.01 \\
(0.35)\end{array}$ \\
\hline Atlantic Trade x 1800 & & & $\begin{array}{l}0.030 \\
(0.016)\end{array}$ & $\begin{array}{l}0.015 \\
(0.014)\end{array}$ & $\begin{array}{c}0.066 \\
(0.026)\end{array}$ & $\begin{array}{l}0.029 \\
(0.021)\end{array}$ & $\begin{array}{l}0.022 \\
(0.014)\end{array}$ & $\begin{array}{l}1.34 \\
(0.55)\end{array}$ & $\begin{array}{l}0.98 \\
(0.49)\end{array}$ & $\begin{array}{l}2.03 \\
(0.91)\end{array}$ & $\begin{array}{l}0.62 \\
(0.32)\end{array}$ \\
\hline Atlantic Trade x 1850 & & & $\begin{array}{c}0.059 \\
(0.014)\end{array}$ & $\begin{array}{l}0.045 \\
(0.013)\end{array}$ & $\begin{array}{c}0.070 \\
(0.026)\end{array}$ & $\begin{array}{c}0.058 \\
(0.019)\end{array}$ & $\begin{array}{c}0.038 \\
(0.014)\end{array}$ & $\begin{array}{l}2.43 \\
(0.49)\end{array}$ & $\begin{array}{l}2.08 \\
(0.43)\end{array}$ & $\begin{array}{l}2.45 \\
(0.91)\end{array}$ & $\begin{array}{l}1.13 \\
(0.30)\end{array}$ \\
\hline R-Squared & 0.89 & 0.87 & 0.90 & 0.88 & 0.79 & 0.83 & 0.92 & 0.92 & 0.90 & 0.78 & 0.91 \\
\hline Number of Observations & 192 & 240 & 192 & 240 & 192 & 208 & 184 & 192 & 240 & 192 & 192 \\
\hline $\begin{array}{l}\text { p-value for Western Europe } x \\
\text { year dummies, 1600-1850 }\end{array}$ & {$[0.00]$} & {$[0.00]$} & {$[0.25]$} & {$[0.02]$} & $\begin{array}{l}\text { anel B: str } \\
\quad[0.91]\end{array}$ & $\begin{array}{l}\text { uctured spe } \\
\quad[0.00]\end{array}$ & $\begin{array}{c}\text { rification } \\
{[0.14]}\end{array}$ & {$[0.04]$} & {$[0.003]$} & {$[0.91]$} & {$[0.04]$} \\
\hline Atlantic Trade $\mathrm{x}$ & & & 0.0073 & 0.0044 & 0.0079 & 0.0072 & 0.0045 & 0.35 & 0.25 & 0.27 & 0.15 \\
\hline Volume of Aggregate Atlantic Trade & & & $(0.0019)$ & $(0.0016)$ & $(0.0031)$ & $(0.0025)$ & $(0.0017)$ & $(0.07)$ & $(0.06)$ & $(0.11)$ & $(0.04)$ \\
\hline R-Squared & 0.89 & 0.87 & 0.90 & 0.88 & 0.78 & 0.83 & 0.92 & 0.90 & 0.88 & 0.78 & 0.90 \\
\hline Number of Observations & 192 & 240 & 192 & 240 & 192 & 208 & 184 & 192 & 240 & 192 & 192 \\
\hline
\end{tabular}

Standard errors are in parentheses. Panel regressions with full set of country and year dummies; regressions are weighted unless otherwise stated. Weighted regressions use total population in each year as weights, from McEvedy and Jones. Dependent variable is level of urbanization excluding urbanization in Atlantic ports (percent of population living in towns with more than 5,000 population that are not on the Atlantic.) Urbanization in Europe is from Bairoch, Batou and Chèvre, and urbanization in Asia is from Bairoch. We report results with three different measures of Atlantic trade: a dummy for whether a country was an Atlantic trader (one for Britain, the Netherlands, France, Spain and Portugal; zero for all others) in columns 3, 4, 5, 6 and 7; the ratio of Atlantic coastline to land area, defining the Atlantic broadly to include Belgium, Denmark, Germany, and Norway (columns 8, 9, and 10); the average percentage population in Atlantic ports during 1300-1850 is multiplied by 100 (column 11). Column 6 includes the available data on Asia (just for India and China) and column 7 drops Britain. Total Atlantic Trade is the log average number of voyages per year.

For more detailed data definitions and sources see Appendix Table 1. 
Table 9 (part 1 of 2)

Atlantic Trade and Institutions

\begin{tabular}{|c|c|c|c|c|c|c|c|c|c|}
\hline & $\begin{array}{c}\text { Panel, 1300- } \\
1850 \\
(1) \\
\end{array}$ & $\begin{array}{l}\text { Panel, } 1300-1850 \\
(2)\end{array}$ & $\begin{array}{c}\text { Panel, } 1300- \\
1850 \\
(3) \\
\end{array}$ & $\begin{array}{l}\text { Panel, 1300- } \\
1850, \\
\text { controlling for } \\
\text { religion } \\
(4)\end{array}$ & $\begin{array}{l}\text { Panel, } 1300 \text { to } \\
1850 \text {, } \\
\text { controlling for } \\
\text { wars } \\
(5)\end{array}$ & $\begin{array}{l}\text { Panel, } 1300 \text { to } \\
1850 \text {, controlling } \\
\text { for Roman } \\
\text { heritage } \\
(6)\end{array}$ & $\begin{array}{l}\text { Panel, } 1300 \text { to } \\
\text { 1850, controlling } \\
\text { for latitude } \\
\text { (7) }\end{array}$ & $\begin{array}{c}\text { Panel, } 1300 \text { to } \\
\text { 1850, using } \\
\text { Atlantic coast-area } \\
\text { measure of Atlantic } \\
\text { trade } \\
\text { (8) }\end{array}$ & $\begin{array}{l}\text { Panel, } 1300 \text { to } \\
1850 \text {, using } \\
\text { Atlantic coast-area } \\
\text { measure of Atlantic } \\
\text { trade } \\
(9) \\
\end{array}$ \\
\hline $\begin{array}{l}\text { p-value for Western Europe x } \\
\text { year dummies, 1600-1850 }\end{array}$ & {$[0.00]$} & {$[0.35]$} & $\begin{array}{l}\text { Pan } \\
{[0.00]}\end{array}$ & $\begin{array}{l}\text { el A: Depend } \\
\quad[0.00]\end{array}$ & $\begin{array}{l}\text { lent Variable } \\
\quad[0.00]\end{array}$ & $\begin{array}{l}\text { is Constraint or } \\
{[0.26]}\end{array}$ & $\begin{array}{l}\text { In Executive } \\
{[0.00]}\end{array}$ & {$[0.00]$} & {$[0.00]$} \\
\hline Atlantic Trade x 1500 & & $\begin{array}{l}-0.42 \\
(0.47)\end{array}$ & & & & & & $\begin{array}{l}-20.83 \\
(22.94)\end{array}$ & \\
\hline Atlantic Trade x 1600 & & $\begin{array}{l}-0.14 \\
(0.52)\end{array}$ & & & & & & $\begin{array}{l}10.94 \\
(22.91)\end{array}$ & \\
\hline Atlantic Trade x 1700 & & $\begin{array}{l}0.29 \\
(0.48)\end{array}$ & & & & & & $\begin{array}{l}62.12 \\
(21.14)\end{array}$ & \\
\hline Atlantic Trade x 1750 & & $\begin{array}{l}0.32 \\
(0.46)\end{array}$ & & & & & & $\begin{array}{l}81.45 \\
(20.78)\end{array}$ & \\
\hline Atlantic Trade x 1800 & & $\begin{array}{l}2.07 \\
(0.44)\end{array}$ & & & & & & $\begin{array}{l}79.81 \\
(18.97)\end{array}$ & \\
\hline Atlantic Trade x 1850 & & $\begin{array}{l}2.96 \\
(0.41)\end{array}$ & & & & & & $\begin{array}{l}72.25 \\
(17.13)\end{array}$ & \\
\hline $\begin{array}{l}\text { Atlantic Trade } \mathrm{x} \\
\text { Volume of Aggregate Atlantic Trade }\end{array}$ & & & $\begin{array}{l}0.42 \\
(0.06)\end{array}$ & $\begin{array}{l}0.45 \\
(0.06)\end{array}$ & $\begin{array}{l}0.43 \\
(0.06)\end{array}$ & $\begin{array}{l}0.39 \\
(0.06)\end{array}$ & $\begin{array}{c}0.43 \\
(0.06)\end{array}$ & & $\begin{array}{l}12.99 \\
(2.31)\end{array}$ \\
\hline $\mathrm{p}$-value for Protestant $\mathrm{x}$ year effect & & & & {$[0.00]$} & & & & & \\
\hline Wars per year in preceding century & & & & & $\begin{array}{c}-0.04 \\
(0.20)\end{array}$ & & & & \\
\hline p-value for Roman Heritage $\mathrm{x}$ Year & & & & & & {$[0.05]$} & & & \\
\hline p-value for Latitude $\mathrm{x}$ Year & & & & & & & {$[0.49]$} & & \\
\hline R-Squared & 0.75 & 0.85 & 0.81 & 0.84 & 0.81 & 0.82 & 0.81 & 0.81 & 0.79 \\
\hline Number of Observations & 192 & 192 & 192 & 192 & 176 & 192 & 192 & 192 & 192 \\
\hline
\end{tabular}


Table 9 (part 2 of 2)

Atlantic Trade and Institutions

\begin{tabular}{|c|c|c|c|c|c|c|c|c|c|}
\hline & $\begin{array}{c}\text { Panel, 1300- } \\
1850 \\
(1) \\
\end{array}$ & $\begin{array}{l}\text { Panel, } 1300-1850 \\
(2)\end{array}$ & $\begin{array}{l}\text { Panel, 1300- } \\
1850 \\
(3) \\
\end{array}$ & $\begin{array}{l}\text { Panel, } 1300- \\
1850, \\
\text { controlling for } \\
\text { religion } \\
(4) \\
\end{array}$ & $\begin{array}{c}\text { Panel, } 1300 \text { to } \\
1850, \\
\text { controlling for } \\
\text { wars } \\
(5)\end{array}$ & $\begin{array}{l}\text { Panel, } 1300 \text { to } \\
1850 \text {, controlling } \\
\text { for Roman } \\
\text { heritage } \\
(6)\end{array}$ & $\begin{array}{l}\text { Panel, } 1300 \text { to } \\
\text { 1850, controlling } \\
\text { for latitude } \\
(7)\end{array}$ & $\begin{array}{c}\text { Panel, } 1300 \text { to } \\
1850 \text {, using } \\
\text { Atlantic coast-area } \\
\text { measure of Atlantic } \\
\text { trade } \\
(8)\end{array}$ & $\begin{array}{l}\text { Panel, } 1300 \text { to } \\
1850 \text {, using } \\
\text { Atlantic coast-area } \\
\text { measure of Atlantic } \\
\text { trade } \\
(9) \\
\end{array}$ \\
\hline & \multicolumn{9}{|c|}{ Panel B: Dependent Variable is Protection for Capital } \\
\hline $\begin{array}{l}\text { p-value for Western Europe x } \\
\text { year dummies, } 1600-1850\end{array}$ & {$[0.00]$} & {$[0.59]$} & {$[0.00]$} & {$[0.00]$} & {$[0.00]$} & {$[0.37]$} & {$[0.00]$} & {$[0.00]$} & {$[0.00]$} \\
\hline Atlantic Trade x 1500 & & $\begin{array}{l}-0.15 \\
(0.47)\end{array}$ & & & & & & $\begin{array}{c}-0.13 \\
(24.96)\end{array}$ & \\
\hline Atlantic Trade x 1600 & & $\begin{array}{l}0.66 \\
(0.52)\end{array}$ & & & & & & $\begin{array}{l}27.51 \\
(24.96)\end{array}$ & \\
\hline Atlantic Trade x 1700 & & $\begin{array}{l}1.09 \\
(0.48)\end{array}$ & & & & & & $\begin{array}{l}78.63 \\
(23.03)\end{array}$ & \\
\hline Atlantic Trade x 1750 & & $\begin{array}{l}1.13 \\
(0.46)\end{array}$ & & & & & & $\begin{array}{l}98.12 \\
(22.65)\end{array}$ & \\
\hline Atlantic Trade x 1800 & & $\begin{array}{l}3.40 \\
(0.43)\end{array}$ & & & & & & $\begin{array}{l}89.84 \\
(20.67)\end{array}$ & \\
\hline Atlantic Trade x 1850 & & $\begin{array}{l}3.73 \\
(0.40)\end{array}$ & & & & & & $\begin{array}{l}87.83 \\
(18.67)\end{array}$ & \\
\hline $\begin{array}{l}\text { Atlantic Trade } \mathrm{x} \\
\text { Volume of Aggregate Atlantic Trade }\end{array}$ & & & $\begin{array}{l}0.56 \\
(0.06)\end{array}$ & $\begin{array}{l}0.61 \\
(0.06)\end{array}$ & $\begin{array}{l}0.56 \\
(0.06)\end{array}$ & $\begin{array}{l}0.54 \\
(0.06)\end{array}$ & $\begin{array}{l}0.57 \\
(0.06)\end{array}$ & & $\begin{array}{l}14.31 \\
(2.49)\end{array}$ \\
\hline $\mathrm{p}$-value for Protestant $\mathrm{x}$ year effect & & & & {$[0.00]$} & & & & & \\
\hline Wars per year in preceding century & & & & & $\begin{array}{l}-0.06 \\
(0.20)\end{array}$ & & & & \\
\hline p-value for Roman Heritage x Year & & & & & & {$[0.07]$} & & & \\
\hline p-value for Latitude x Year & & & & & & & {$[0.58]$} & & \\
\hline R-Squared & 0.73 & 0.86 & 0.83 & 0.85 & 0.83 & 0.84 & 0.83 & 0.79 & 0.77 \\
\hline Number of Observations & 192 & 192 & 192 & 192 & 176 & 192 & 192 & 192 & 192 \\
\hline
\end{tabular}

Standard errors are in parentheses. Weighted panel regressions with full set of country and year dummies. Weights are total population in each country in each year, from McEvedy and Jones. Dependent variables are constraint on executive in columns 1-8 and protection for capital in columns 9-16, coded from Langer, as explained in the Appendix. All columns use the Atlantic trader dummy (one for Britain, France, Spain, Portugal and the Netherlands; zero for all others) as the measure of Atlantic trade, apart from columns 7, 8, 15 and 16 which use the ratio of Atlantic coastline (broadly defined to include Belgium, Denmark, Germany, Ireland and Norway) to land area. Total Atlantic Trade is the log average number of voyages per year. Protestant is a dummy for whether country was majority Protestant in 1600 . Protestant $x$ Year is the Protestant dummy interacted with year dummies for 1600 and after. Wars per year are for the preceding century through 1700, 1700-1750 for $1750,1750-1800$ for 1800 and 1800-1850 for 1850. Roman heritage is dummy for whether country was in Roman empire and not subsequently in Ottoman empire; this is interacted with year dummies for 1600 and after.

Latitude is distance from the equator for capital city of this country today; this is interacted with year for 1600 and after. For more detailed data definitions and sources see Appendix Table 1. 
Table 10A

Interaction Between Initial Institutions and Atlantic Trade

Atlantic Trader $\mathrm{x}$

Volume of Aggregate Atlantic Trade

p-value for Initial Institutions x year

$(1600,1700,1750,1800,1850)$

Total Atlantic Trade x Initial Institutions x Atlantic Trader

R-Squared

Number of Observations

Atlantic Trader $x$

Volume of Aggregate Atlantic Trade

p-value for Initial Institutions x year

$(1600,1700,1750,1800,1850)$

Total Atlantic Trade x Initial Institutions x Atlantic Trader

R-Squared

Number of Observations

Atlantic Trader $\mathrm{x}$

Volume of Aggregate Atlantic Trade

p-value for Initial Institutions $x$ year

$(1600,1700,1750,1800,1850)$

Total Atlantic Trade x Initial Institutions x Atlantic Trader

R-Squared

Number of Observations

Using Atlantic trader dummy as measure of Atlantic trade

\begin{tabular}{|c|c|c|c|c|c|c|c|c|c|}
\hline$(1)$ & (2) & (3) & (4) & (5) & (6) & (7) & (8) & (9) & (10) \\
\hline \multicolumn{10}{|c|}{ Panel A: Dependent Variable is Urbanization } \\
\hline $\begin{array}{l}\text { Panel, } 1300- \\
1850\end{array}$ & $\begin{array}{l}\text { Panel, } 1300- \\
\quad 1850 \\
\end{array}$ & $\begin{array}{c}\text { Panel, } 1300- \\
1850\end{array}$ & $\begin{array}{c}\text { Panel, } 1300- \\
1850 \\
\end{array}$ & $\begin{array}{c}\text { Panel, } 1300- \\
1850, \\
\text { unweighted }\end{array}$ & $\begin{array}{l}\text { Panel, } 1000- \\
\quad 1850\end{array}$ & $\begin{array}{c}\text { Panel, } 1000- \\
\quad 1850 \\
\end{array}$ & $\begin{array}{l}\text { Panel, } 1000- \\
\quad 1850\end{array}$ & $\begin{array}{c}\text { Panel, } 1000- \\
1850\end{array}$ & $\begin{array}{c}\text { Panel, 1000- } \\
1850, \\
\text { unweighted }\end{array}$ \\
\hline \multirow{3}{*}[0.61]{} & $\begin{array}{l}0.011 \\
(0.002)\end{array}$ & $\begin{array}{l}0.011 \\
(0.002)\end{array}$ & $\begin{array}{c}-0.0090 \\
(0.0049)\end{array}$ & $\begin{array}{c}-0.0026 \\
(0.0062)\end{array}$ & & $\begin{array}{l}0.0082 \\
(0.0020)\end{array}$ & $\begin{array}{l}0.0084 \\
(0.0020)\end{array}$ & $\begin{array}{l}-0.012 \\
(0.004)\end{array}$ & $\begin{array}{l}-0.009 \\
(0.005)\end{array}$ \\
\hline & & {$[0.51]$} & {$[0.71]$} & {$[0.85]$} & {$[0.12]$} & & {$[0.08]$} & {$[0.42]$} & {$[0.92]$} \\
\hline & & & $\begin{array}{l}0.021 \\
(0.004)\end{array}$ & $\begin{array}{l}0.017 \\
(0.005)\end{array}$ & & & & $\begin{array}{l}0.021 \\
(0.004)\end{array}$ & $\begin{array}{c}0.022 \\
(0.004)\end{array}$ \\
\hline 0.87 & 0.88 & 0.89 & 0.90 & 0.83 & 0.86 & 0.86 & 0.87 & 0.87 & 0.81 \\
\hline 192 & 192 & 192 & 192 & 192 & 240 & 240 & 240 & 240 & 240 \\
\hline \multicolumn{10}{|c|}{ Panel B: Dependent Variable is Log GDP per capita } \\
\hline $\begin{array}{l}\text { Panel, } 1500- \\
\quad 1820\end{array}$ & $\begin{array}{c}\text { Panel, } 1500- \\
\quad 1820 \\
\end{array}$ & $\begin{array}{c}\text { Panel, } 1500- \\
\quad 1820\end{array}$ & $\begin{array}{c}\text { Panel, } 1500- \\
\quad 1820\end{array}$ & $\begin{array}{c}\text { Panel, 1500- } \\
1820, \\
\text { unweighted }\end{array}$ & $\begin{array}{l}\text { Panel, } 1500- \\
\quad 1870\end{array}$ & $\begin{array}{c}\text { Panel, } 1500- \\
\quad 1870 \\
\end{array}$ & $\begin{array}{l}\text { Panel, } 1500- \\
\quad 1870\end{array}$ & $\begin{array}{l}\text { Panel, } 1500- \\
\quad 1870\end{array}$ & $\begin{array}{c}\text { Panel, } 1500- \\
1870, \\
\text { unweighted }\end{array}$ \\
\hline \multirow{3}{*}[0.40]{} & $\begin{array}{l}0.069 \\
(0.016)\end{array}$ & $\begin{array}{l}0.068 \\
(0.016)\end{array}$ & $\begin{array}{l}-0.068 \\
(0.028)\end{array}$ & $\begin{array}{l}-0.079 \\
(0.028)\end{array}$ & \multirow{3}{*}[0.66]{} & \multirow[t]{3}{*}{$\begin{array}{l}0.004 \\
(0.017)\end{array}$} & $\begin{array}{c}0.039 \\
(0.017)\end{array}$ & $\begin{array}{l}-0.122 \\
(0.030)\end{array}$ & $\begin{array}{l}-0.110 \\
(0.028)\end{array}$ \\
\hline & & {$[0.31]$} & {$[0.004]$} & {$[0.08]$} & & & \multirow[t]{2}{*}[0.64]{} & {$[0.01]$} & {$[0.58]$} \\
\hline & & & $\begin{array}{l}0.14 \\
(0.03)\end{array}$ & $\begin{array}{l}0.12 \\
(0.02)\end{array}$ & & & & $\begin{array}{l}0.16 \\
(0.03)\end{array}$ & $\begin{array}{l}0.11 \\
(0.02)\end{array}$ \\
\hline 0.94 & 0.96 & 0.96 & 0.97 & 0.97 & 0.95 & 0.95 & 0.95 & 0.96 & 0.96 \\
\hline \multirow[t]{2}{*}{96} & 96 & 96 & 96 & 96 & 120 & 120 & 120 & 120 & 120 \\
\hline & \multicolumn{8}{|c|}{ Panel C: Dependent Variable is Constraint on the Executive } & \\
\hline $\begin{array}{l}\text { Panel, } 1300- \\
1850\end{array}$ & $\begin{array}{l}\text { Panel, } 1300- \\
\quad 1850\end{array}$ & $\begin{array}{l}\text { Panel, } 1300- \\
\quad 1850\end{array}$ & $\begin{array}{c}\text { Panel, } 1300- \\
\quad 1850\end{array}$ & $\begin{array}{c}\text { Panel, } 1300- \\
1850, \\
\text { unweighted }\end{array}$ & $\begin{array}{l}\text { Panel, } 1500- \\
1850\end{array}$ & $\begin{array}{l}\text { Panel, } 1500- \\
\quad 1850\end{array}$ & $\begin{array}{l}\text { Panel, } 1500- \\
\quad 1850\end{array}$ & $\begin{array}{l}\text { Panel, } 1500- \\
1850\end{array}$ & $\begin{array}{c}\text { Panel, } 1500- \\
1850, \\
\text { unweighted }\end{array}$ \\
\hline \multirow{3}{*}[0.27]{} & $\begin{array}{l}0.42 \\
(0.06)\end{array}$ & $\begin{array}{l}0.42 \\
(0.06)\end{array}$ & $\begin{array}{l}-0.001 \\
(0.12)\end{array}$ & $\begin{array}{l}-0.096 \\
(0.12)\end{array}$ & \multirow{3}{*}[0.43]{} & $\begin{array}{c}0.35 \\
(0.05)\end{array}$ & $\begin{array}{c}0.34 \\
(0.05)\end{array}$ & $\begin{array}{l}-0.11 \\
(0.10)\end{array}$ & $\begin{array}{l}-0.15 \\
(0.09)\end{array}$ \\
\hline & & {$[0.14]$} & {$[0.008]$} & {$[0.69]$} & & & {$[0.33]$} & {$[0.01]$} & {$[0.95]$} \\
\hline & & & $\begin{array}{l}0.44 \\
(0.11)\end{array}$ & $\begin{array}{l}0.26 \\
(0.09)\end{array}$ & & & & $\begin{array}{c}0.47 \\
(0.09)\end{array}$ & $\begin{array}{c}0.29 \\
(0.07)\end{array}$ \\
\hline 0.76 & 0.81 & 0.82 & 0.84 & 0.76 & 0.72 & 0.77 & 0.78 & 0.70 & 0.71 \\
\hline 192 & 192 & 192 & 192 & 192 & 240 & 240 & 240 & 240 & 240 \\
\hline
\end{tabular}

Standard errors are in parentheses. Weighted panel regressions with full set of country and year dummies. Weights are total population in each country in each year, from McEvedy and Jones. Dependent variable is urbanization in Panel A, log GDP per capita in Panel B, and Constraint on the executive in Panel C. Western Europe dummies interacted with years (from 1600) are included in all columns, but not reported to save space. Urbanization in Europe is from Bairoch, Batou and Chèvre, and urbanization in Asia is from Bairoch. Log GDP per capita is from Maddison. Constraint on the executive is coded from Langer; initial institutions are the average of institutions in 1400 and 1500. We use the Atlantic trader dummy as the measure of Atlantic trade. Total Atlantic Trade is the log average number of voyages per year. Total Atlantic trade is demeaned. Main effects are evaluated at initial institutions equal to one. For data definitions and sources see Appendix Table 1. 
Table 10B

Interaction Between Initial Institutions and Atlantic Trade

\begin{tabular}{|c|c|c|c|c|c|c|c|c|c|c|}
\hline & \multicolumn{10}{|c|}{ Using coastline-to-area ratio as measure of Atlantic trade } \\
\hline & $(1)$ & $(2)$ & $(3)$ & $(4)$ & $(4)$ & $(5)$ & $(6)$ & $(7)$ & $(8)$ & $(8)$ \\
\hline & \multicolumn{10}{|c|}{ Panel A: Dependent Variable is Urbanization } \\
\hline & Panel, $1300-1850$ & $\begin{array}{c}\text { Panel, 1300- } \\
1850\end{array}$ & $\begin{array}{c}\text { Panel, 1300- } \\
1850\end{array}$ & $\begin{array}{c}\text { Panel, } 1300- \\
1850\end{array}$ & $\begin{array}{c}\text { Panel, } 1300- \\
1850 \\
\text { unweighted }\end{array}$ & $\begin{array}{c}\text { Panel, 1000- } \\
1850\end{array}$ & $\begin{array}{c}\text { Panel, 1000- } \\
1850\end{array}$ & $\begin{array}{c}\text { Panel, 1000- } \\
1850\end{array}$ & $\begin{array}{c}\text { Panel, 1000- } \\
1850\end{array}$ & $\begin{array}{c}\text { Panel, 1000- } \\
1850, \\
\text { unweighted }\end{array}$ \\
\hline $\begin{array}{l}\text { Atlantic Coastline-to-area x } \\
\text { Volume of Aggregate Atlantic Trade }\end{array}$ & & $\begin{array}{l}0.74 \\
(0.07)\end{array}$ & $\begin{array}{l}0.74 \\
(0.07)\end{array}$ & $\begin{array}{l}0.30 \\
(0.28)\end{array}$ & $\begin{array}{l}0.13 \\
(0.30)\end{array}$ & & $\begin{array}{l}0.64 \\
(0.06)\end{array}$ & $\begin{array}{l}0.64 \\
(0.06)\end{array}$ & $\begin{array}{c}0.20 \\
(0.25)\end{array}$ & $\begin{array}{l}-0.12 \\
(0.25)\end{array}$ \\
\hline $\begin{array}{l}\text { p-value for Institutions in } 1500 \times \text { year } \\
(1600,1700,1750,1800,1850)\end{array}$ & {$[0.61]$} & & {$[0.45]$} & {$[0.30]$} & {$[0.97]$} & {$[0.12]$} & & {$[0.12]$} & {$[0.04]$} & {$[0.40]$} \\
\hline $\begin{array}{l}\text { Total Atlantic Trade x Institutions in } 1500 \\
\text { x Atlantic Coastline-to-area }\end{array}$ & & & & $\begin{array}{l}0.44 \\
(0.28)\end{array}$ & $\begin{array}{l}0.52 \\
(0.29)\end{array}$ & & & & $\begin{array}{l}0.43 \\
(0.24)\end{array}$ & $\begin{array}{c}0.61 \\
(0.24)\end{array}$ \\
\hline R-Squared & 0.87 & 0.93 & 0.93 & 0.93 & 0.83 & 0.86 & 0.91 & 0.91 & 0.91 & 0.78 \\
\hline \multirow[t]{3}{*}{ Number of Observations } & 192 & 192 & 192 & 192 & 192 & 240 & 240 & 240 & 240 & 240 \\
\hline & \multicolumn{10}{|c|}{ Panel B: Dependent Variable is Log GDP per capita } \\
\hline & Panel, $1500-1820$ & $\begin{array}{l}\text { Panel, } 1500- \\
1820\end{array}$ & $\begin{array}{l}\text { Panel, } 1500- \\
1820\end{array}$ & $\begin{array}{l}\text { Panel, } 1500- \\
1820\end{array}$ & $\begin{array}{c}\text { Panel, } 1500- \\
1820, \\
\text { unweighted }\end{array}$ & $\begin{array}{l}\text { Panel, } 1500- \\
\quad 1870\end{array}$ & $\begin{array}{l}\text { Panel, } 1500- \\
\quad 1870 \\
\end{array}$ & $\begin{array}{l}\text { Panel, } 1500- \\
\quad 1870 \\
\end{array}$ & $\begin{array}{c}\text { Panel, 1500- } \\
1870\end{array}$ & $\begin{array}{c}\text { Panel, 1500- } \\
1870, \\
\text { unweighted }\end{array}$ \\
\hline $\begin{array}{l}\text { Atlantic Coastline-to-area x } \\
\text { Volume of Aggregate Atlantic Trade }\end{array}$ & & $\begin{array}{l}3.38 \\
(0.56)\end{array}$ & $\begin{array}{l}2.99 \\
(0.44)\end{array}$ & $\begin{array}{l}-3.42 \\
(1.82)\end{array}$ & $\begin{array}{l}-2.76 \\
(1.48)\end{array}$ & & $\begin{array}{l}2.82 \\
(0.45)\end{array}$ & $\begin{array}{l}2.99 \\
(0.44)\end{array}$ & $\begin{array}{l}-3.42 \\
(1.82)\end{array}$ & $\begin{array}{l}-3.66 \\
(1.18)\end{array}$ \\
\hline $\begin{array}{l}\text { p-value for Institutions in } 1500 \times \text { year } \\
(1600,1700,1750,1800,1850)\end{array}$ & {$[0.66]$} & & {$[0.11]$} & {$[0.96]$} & {$[0.39]$} & {$[0.66]$} & & {$[0.11]$} & {$[0.96]$} & {$[0.17]$} \\
\hline $\begin{array}{l}\text { Total Atlantic Trade x Institutions in } 1500 \\
\text { x Atlantic Coastline-to-area }\end{array}$ & & & & $\begin{array}{l}6.28 \\
(1.74)\end{array}$ & $\begin{array}{l}5.40 \\
(1.42)\end{array}$ & & & & $\begin{array}{l}6.28 \\
(1.74)\end{array}$ & $\begin{array}{l}5.80 \\
(1.13)\end{array}$ \\
\hline R-Squared & 0.95 & 0.96 & 0.97 & 0.97 & 0.97 & 0.95 & 0.96 & 0.97 & 0.97 & 0.97 \\
\hline \multirow[t]{2}{*}{ Number of Observations } & 96 & 96 & 96 & 96 & 96 & 120 & 120 & 120 & 120 & 120 \\
\hline & Panel, $1300-1850$ & $\begin{array}{c}\text { Panel, 1300- } \\
1850\end{array}$ & $\begin{array}{c}\text { Panel C } \\
\text { Panel, 1300- } \\
1850\end{array}$ & $\begin{array}{l}\text { Dependent } \\
\text { Panel, 1300- } \\
1850\end{array}$ & $\begin{array}{c}\text { Cariable is } \\
\text { Panel, } 1300- \\
1850, \\
\text { unweighted }\end{array}$ & $\begin{array}{l}\text { Constraint o } \\
\text { Panel, 1000- } \\
1850\end{array}$ & $\begin{array}{l}\text { In the Exec } \\
\text { Panel, 1000- } \\
1850\end{array}$ & $\begin{array}{l}\text { itive } \\
\text { Panel, 1000- } \\
1850\end{array}$ & $\begin{array}{c}\text { Panel, 1000- } \\
1850\end{array}$ & $\begin{array}{l}\text { Panel, } 1000- \\
\quad 1850, \\
\text { unweighted }\end{array}$ \\
\hline $\begin{array}{l}\text { Atlantic Coastline-to-area x } \\
\text { Volume of Aggregate Atlantic Trade }\end{array}$ & & $\begin{array}{l}11.97 \\
(2.21)\end{array}$ & $\begin{array}{l}12.96 \\
(2.18)\end{array}$ & $\begin{array}{l}-12.58 \\
(9.22)\end{array}$ & $\begin{array}{l}-3.02 \\
(5.43)\end{array}$ & & $\begin{array}{l}13.08 \\
(1.71)\end{array}$ & $\begin{array}{l}13.83 \\
(1.69)\end{array}$ & $\begin{array}{l}-6.74 \\
(7.10)\end{array}$ & $\begin{array}{c}0.14 \\
(4.19)\end{array}$ \\
\hline $\begin{array}{l}\text { p-value for Institutions in } 1500 \times \text { year } \\
(1600,1700,1750,1800,1850)\end{array}$ & {$[0.26]$} & & {$[0.03]$} & {$[0.83]$} & {$[0.88]$} & {$[0.43]$} & & {$[0.03]$} & {$[0.81]$} & {$[0.87]$} \\
\hline $\begin{array}{l}\text { Total Atlantic Trade x Institutions in } 1500 \\
\text { x Atlantic Coastline-to-area }\end{array}$ & & & & $\begin{array}{l}25.19 \\
(8.85)\end{array}$ & $\begin{array}{l}13.56 \\
(5.26)\end{array}$ & & & & $\begin{array}{l}20.30 \\
(6.82)\end{array}$ & $\begin{array}{l}11.61 \\
(4.07)\end{array}$ \\
\hline R-Squared & 0.76 & 0.78 & 0.80 & 0.82 & 0.78 & 0.72 & 0.78 & 0.79 & 0.80 & 0.74 \\
\hline Number of Observations & 192 & 192 & 192 & 192 & 192 & 240 & 240 & 240 & 240 & 240 \\
\hline
\end{tabular}

Standard errors are in parentheses. Weighted panel regressions with full set of country and year dummies. Weights are total population in each country in each year, from McEvedy and Jones. Dependent variable is urbanization in Panel A, log GDP per capita in Panel B, and Constraint on the executive in Panel C. Western Europe dummies interacted with years (from 1600) are included in all columns, but not reported to save space. Urbanization in Europe is from Bairoch, Batou and Chèvre, and urbanization in Asia is from Bairoch. Log GDP per capita is from Maddison. Constraint on the executive is coded from Langer; initial institutions are the average of institutions in 1400 and 1500. We use the ratio of Atlantic coastline to land area (defined broadly to include Belgium, Denmark, Germany, Ireland, and Norway) as the measure of Atlantic trade. Total Atlantic Trade is the log average number of voyages per year. Total Atlantic trade is demeaned. Main effects are evaluated at initial institutions equal to one. For data definitions and sources see Appendix Table 1. 
Appendix Table 1

Variable Definitions and Sources

$\frac{\text { Variable }}{\text { Log GDP per capita in } 1500,1600,1700,1820 \text { and } 1870}$

Population in 1000, 1200, 1300, 1400, 1500, 1600, 1700, 1750,1800 , and 1850 .

Urban population in 1000, 1200, 1300, 1400, 1500, 1600, $1700,1750,1800$, and 1850.

Atlantic and Mediteranean ports

Ratio of Atlantic coastline to land area

Average percent population living in Atlantic ports, 13001850

Dummy for Atlantic trader

Dummy for Atlantic port.

Dummy for potential Atlantic port

Total Atlantic Trade

Non-Atlantic Urbanization

Constraint on executive in 1800, 1850, 1960, 1970, 1990 and intervening years.

Constraint on executive from 1000 to 1800

Protection for capital from 1000 to 1850 .

Religion Variables

Roman heritage

Wars per year

\section{Logarithm of GDP per capita.}

Maddison (2001)

Source

Total population.

Population living in urban areas; see appendix for details.

City that is on the Atlantic or Mediteranean
McEvedy and Jones (1978)

Bairoch, Batou and Chèvre (1988), as described in the appendix. We use Bairoch (1988) for urbanization in Asia and Chandler for Asian city population.

Bairoch, Batou and Chèvre (1988) for cities; location from DK Publishing (1997). Length of Atlantic coastline divided by land area. Both assume modern borders. Atlantic coastline includes the $\quad$ Coastline is from Integrated Coastline Management (on the web.) Land area is from
whole coast of Portugal, Ireland, Belgium, the Netherlands, and Britain. It also includes half the coastline of Spain, the World Bank, World Development Indicators, CD-Rom, 1999. whole coast of Portugal, Ireland, Belgium, the Netherlands, and Britain. It also includes half the coastline of Spain, two-thirds the coastline of France, half the coastline of Germany, one quarter the coastline of Denmark, and half the coastline of Norway

Population living in Atlantic ports divided by total population.

Equals one for Britain, France, the Netherlands, Portugal, and Spain

Urban population from Bairoch, Batou and Chèvre (1988); total population from McEvedy and Jones (1978); location from DK Publishing (1997).

See Appendix for details

Equals one for a city that was used as an Atlantic port; zero otherwise.

Bairoch, Batou and Chèvre (1988) for cities; location from DK Publishing (1997).

Equals one for a city that is on the Atlantic; zero otherwise.

Average voyages per year equivalent; see appendix for details.

Total urban population not in Atlantic cities divided by total population.
Bairoch, Batou and Chèvre (1988) for cities; location from DK Publishing (1997)

See appendix for details

Urban population from Bairoch, Batou and Chèvre (1988); total population from McEvedy and Jones (1978); location from DK Publishing (1997).

A seven category scale, from 1 to 7, with a higher score indicating more constraints. Score of 1 indicates unlimited Polity IV dataset, downloaded from Inter-University Consortium for Political and authority; score of 3 indicates slight to moderate limitations; score of 5 indicates substantial limitations; score of 7 Social Research. Variable described in Gurr 1997. indicates executive parity or subordination. Scores of 2,4 , and 6 indicate intermediate values.

A seven category scale, from 1 to 7, with a higher score indicating more constraints. Score of 1 indicates unlimited Coded by authors from Langer (1972); see appendix for more details. authority; score of 3 indicates slight to moderate limitations; score of 5 indicates substantial limitations; score of 7

indicates executive parity or subordination. Scores of 2,4 , and 6 indicate intermediate values.

A seven category scale, from 1 to 7 , with a higher score indicating more constraints. Score of 1 indicates no protection; score of 3 indicates slight to moderate protection (e.g. city charters); score of 5 indicates ses no

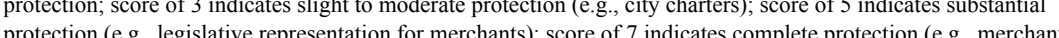
protection (e.g., legislative representation for merchants); score of 7 indica
control the executive.) Scores of 2,4 , and 6 indicate intermediate values.

Majority religion of city or country.

Coded by authors from Langer (1972).

Coded equal to one for countries that were part of the Roman empire and not subsequently part of the Ottoman empire.

Number of years of war in preceding 50 or 100 years. Civil wars and colonial wars outside Europe are excluded.

Coded by authors from Langer (1972).

Coded by authors from Kohn (1999)

Latitude

Coded by authors from Langer (1972); see appendix for more details. s. 
Appendix Table 2

Key Data

\begin{tabular}{|c|c|c|c|c|c|}
\hline Country & Date & Urbanization & $\begin{array}{l}\text { GDP per } \\
\text { capita }\end{array}$ & $\begin{array}{l}\text { Constraint } \\
\text { on Executive }\end{array}$ & $\begin{array}{c}\text { Protection for } \\
\text { Capital }\end{array}$ \\
\hline Albania & 1000 & 0.00 & • & 1 & 1 \\
\hline Albania & 1100 & & . & 1 & 1 \\
\hline Albania & 1200 & 12.50 & . & 1 & 1 \\
\hline Albania & 1300 & 12.50 & . & 1 & 1 \\
\hline Albania & 1400 & 1.00 & . & 1 & 1 \\
\hline Albania & 1500 & 2.50 & 462 & 1 & 1 \\
\hline Albania & 1600 & 21.00 & 516 & 1 & 1 \\
\hline Albania & 1700 & 15.33 & 566 & 1 & 1 \\
\hline Albania & 1750 & 8.00 & . & 1 & 1 \\
\hline Albania & 1800 & 28.00 & 636 & 1 & 1 \\
\hline Albania & 1850 & 21.80 & 871 & 1 & 1 \\
\hline Austria & 1000 & 0.00 & . & 1 & 1 \\
\hline Austria & 1100 & & - & 1 & 1 \\
\hline Austria & 1200 & 0.96 & - & 1 & 1 \\
\hline Austria & 1300 & 1.30 & - & 1 & 1 \\
\hline Austria & 1400 & 2.16 & - & 1 & 1 \\
\hline Austria & 1500 & 3.15 & 707 & 1 & 1 \\
\hline Austria & 1600 & 4.52 & 837 & 1 & 1 \\
\hline Austria & 1700 & 7.40 & 993 & 1 & 1 \\
\hline Austria & 1750 & 9.85 & - & 1 & 1 \\
\hline Austria & 1800 & 12.73 & 1218 & 1 & 1 \\
\hline Austria & 1850 & 15.75 & 1863 & 1 & 1 \\
\hline Belgium & 1000 & 8.25 & • & 3 & 3 \\
\hline Belgium & 1100 & & . & 3 & 3 \\
\hline Belgium & 1200 & 15.67 & . & 3 & 3 \\
\hline Belgium & 1300 & 17.04 & . & 3 & 3 \\
\hline Belgium & 1400 & 48.13 & . & 3 & 3 \\
\hline Belgium & 1500 & 30.08 & 875 & 3 & 3 \\
\hline Belgium & 1600 & 22.80 & 976 & 2 & 2 \\
\hline Belgium & 1700 & 29.77 & 1144 & 2 & 2 \\
\hline Belgium & 1750 & 23.02 & . & 2 & 2 \\
\hline Belgium & 1800 & 22.80 & 1319 & 4 & 4 \\
\hline Belgium & 1850 & 25.38 & 2697 & 5 & 5 \\
\hline Bulgaria & 1000 & 8.75 & - & 1 & 1 \\
\hline Bulgaria & 1100 & & - & 1 & 1 \\
\hline Bulgaria & 1200 & 5.79 & - & 1 & 1 \\
\hline Bulgaria & 1300 & 14.20 & - & 1 & 1 \\
\hline Bulgaria & 1400 & 5.07 & - & 1 & 1 \\
\hline Bulgaria & 1500 & 12.13 & 462 & 1 & 1 \\
\hline Bulgaria & 1600 & 8.24 & 516 & 1 & 1 \\
\hline Bulgaria & 1700 & 10.08 & 566 & 1 & 1 \\
\hline Bulgaria & 1750 & 8.94 & • & 1 & 1 \\
\hline Bulgaria & 1800 & 14.25 & 636 & 1 & 1 \\
\hline Bulgaria & 1850 & 13.48 & 871 & 1 & 1 \\
\hline China & 1000 & 2.50 & $\cdot$ & $\cdot$ & $\cdot$ \\
\hline China & 1100 & & . & . & . \\
\hline
\end{tabular}




\begin{tabular}{|c|c|c|c|c|c|}
\hline Country & Date & Urbanization & $\begin{array}{l}\text { GDP per } \\
\text { capita }\end{array}$ & $\begin{array}{l}\text { Constraint } \\
\text { on Executive }\end{array}$ & $\begin{array}{c}\text { Protection for } \\
\text { Capital }\end{array}$ \\
\hline China & 1200 & 1.40 & . & $\cdot$ & $\cdot$ \\
\hline China & 1300 & 2.40 & . & . & . \\
\hline China & 1400 & 2.80 & . & . & . \\
\hline China & 1500 & 2.20 & 600 & . & . \\
\hline China & 1600 & 1.80 & 600 & . & . \\
\hline China & 1700 & 1.90 & 600 & . & . \\
\hline China & 1750 & 1.80 & . & . & . \\
\hline China & 1800 & 1.60 & 600 & . & . \\
\hline China & 1850 & 1.50 & 530 & . & . \\
\hline Czech Republ & 1000 & 0.80 & . & 1 & 1 \\
\hline Czech Republ & 1100 & & . & 1 & 1 \\
\hline Czech Republ & 1200 & 0.50 & . & 1 & 1 \\
\hline Czech Republ & 1300 & 3.70 & . & 2 & 1 \\
\hline Czech Republ & 1400 & 4.84 & . & 2 & 1 \\
\hline Czech Republ & 1500 & 4.60 & 707 & 2 & 1 \\
\hline Czech Republ & 1600 & 3.44 & 837 & 2 & 1 \\
\hline Czech Republ & 1700 & 3.67 & 993 & 1 & 1 \\
\hline Czech Republ & 1750 & 3.58 & . & 1 & 1 \\
\hline Czech Republ & 1800 & 4.86 & 1218 & 1 & 1 \\
\hline Czech Republ & 1850 & 4.17 & 1863 & 1 & 1 \\
\hline Denmark & 1000 & 0.00 & . & 1 & 1 \\
\hline Denmark & 1100 & & . & 1 & 1 \\
\hline Denmark & 1200 & 0.00 & . & 1 & 1 \\
\hline Denmark & 1300 & 0.00 & . & 3 & 1 \\
\hline Denmark & 1400 & 1.80 & . & 2 & 1 \\
\hline Denmark & 1500 & 2.17 & 738 & 2 & 1 \\
\hline Denmark & 1600 & 10.57 & 875 & 1 & 1 \\
\hline Denmark & 1700 & 10.75 & 1039 & 2 & 2 \\
\hline Denmark & 1750 & 12.00 & . & 2 & 2 \\
\hline Denmark & 1800 & 13.50 & 1274 & 1 & 1 \\
\hline Denmark & 1850 & 12.53 & 2003 & 5 & 5 \\
\hline England & 1000 & 5.71 & . & 1 & 1 \\
\hline England & 1100 & & . & 1 & 1 \\
\hline England & 1200 & 2.39 & . & 1 & 1 \\
\hline England & 1300 & 4.49 & . & 3 & 2 \\
\hline England & 1400 & 5.17 & . & 3 & 2 \\
\hline England & 1500 & 6.42 & 762 & 2 & 2 \\
\hline England & 1600 & 9.92 & 1043 & 3 & 3 \\
\hline England & 1700 & 17.16 & 1405 & 5 & 5 \\
\hline England & 1750 & 18.80 & . & 6 & 6 \\
\hline England & 1800 & 28.80 & 1931 & 7 & 7 \\
\hline England & 1850 & 39.03 & 3487 & 7 & 7 \\
\hline Finland & 1000 & 0.00 & . & 1 & 1 \\
\hline Finland & 1100 & & . & 1 & 1 \\
\hline Finland & 1200 & 0.00 & . & 1 & 1 \\
\hline Finland & 1300 & 0.00 & . & 1 & 1 \\
\hline Finland & 1400 & 1.00 & . & 1 & 1 \\
\hline Finland & 1500 & 2.00 & 453 & 1 & 1 \\
\hline
\end{tabular}




\begin{tabular}{|c|c|c|c|c|c|}
\hline Country & Date & Urbanization & $\begin{array}{l}\text { GDP per } \\
\text { capita }\end{array}$ & $\begin{array}{l}\text { Constraint } \\
\text { on Executive }\end{array}$ & $\begin{array}{c}\text { Protection for } \\
\text { Capital }\end{array}$ \\
\hline Finland & 1600 & 3.00 & 538 & 1 & 1 \\
\hline Finland & 1700 & 3.33 & 638 & 1 & 1 \\
\hline Finland & 1750 & 2.36 & . & 1 & 1 \\
\hline Finland & 1800 & 3.38 & 781 & 1 & 1 \\
\hline Finland & 1850 & 4.20 & 1140 & 1 & 1 \\
\hline France & 1000 & 3.92 & . & 1 & 1 \\
\hline France & 1100 & & . & 1 & 1 \\
\hline France & 1200 & 5.53 & . & 3 & 1 \\
\hline France & 1300 & 6.94 & . & 2 & 1 \\
\hline France & 1400 & 8.07 & . & 2 & 1 \\
\hline France & 1500 & 7.60 & 727 & 2 & 1 \\
\hline France & 1600 & 7.80 & 841 & 1 & 1 \\
\hline France & 1700 & 10.98 & 986 & 1 & 1 \\
\hline France & 1750 & 12.07 & . & 1 & 1 \\
\hline France & 1800 & 13.96 & 1230 & 4 & 5 \\
\hline France & 1850 & 16.71 & 1876 & 5 & 5 \\
\hline Germany & 1000 & 5.97 & . & 1 & 1 \\
\hline Germany & 1100 & & . & 1 & 1 \\
\hline Germany & 1200 & 4.67 & . & 1 & 1 \\
\hline Germany & 1300 & 6.97 & . & 1 & 1 \\
\hline Germany & 1400 & 8.17 & . & 1 & 1 \\
\hline Germany & 1500 & 8.60 & 676 & 1 & 1 \\
\hline Germany & 1600 & 8.95 & 777 & 1 & 1 \\
\hline Germany & 1700 & 7.58 & 894 & 1 & 1 \\
\hline Germany & 1750 & 10.08 & . & 1 & 1 \\
\hline Germany & 1800 & 12.86 & 1058 & 1 & 1 \\
\hline Germany & 1850 & 14.09 & 1821 & 1 & 1 \\
\hline Greece & 1000 & 5.50 & . & 1 & 1 \\
\hline Greece & 1100 & & . & 1 & 1 \\
\hline Greece & 1200 & 2.59 & . & 1 & 1 \\
\hline Greece & 1300 & 10.08 & . & 1 & 1 \\
\hline Greece & 1400 & 9.10 & . & 1 & 1 \\
\hline Greece & 1500 & 3.50 & 462 & 1 & 1 \\
\hline Greece & 1600 & 5.53 & 516 & 1 & 1 \\
\hline Greece & 1700 & 4.00 & 566 & 1 & 1 \\
\hline Greece & 1750 & 3.62 & . & 1 & 1 \\
\hline Greece & 1800 & 12.89 & 636 & 1 & 1 \\
\hline Greece & 1850 & 9.10 & 871 & 1 & 1 \\
\hline Hungary & 1000 & 0.40 & . & 1 & 1 \\
\hline Hungary & 1100 & & . & 1 & 1 \\
\hline Hungary & 1200 & 0.00 & . & 2 & 1 \\
\hline Hungary & 1300 & 0.56 & . & 2 & 1 \\
\hline Hungary & 1400 & 1.90 & . & 2 & 1 \\
\hline Hungary & 1500 & 3.28 & 462 & 2 & 1 \\
\hline Hungary & 1600 & 1.84 & 516 & 1 & 1 \\
\hline Hungary & 1700 & 7.20 & 566 & 1 & 1 \\
\hline Hungary & 1750 & 13.55 & . & 1 & 1 \\
\hline Hungary & 1800 & 15.08 & 636 & 1 & 1 \\
\hline
\end{tabular}




\begin{tabular}{|c|c|c|c|c|c|}
\hline Country & Date & Urbanization & $\begin{array}{l}\text { GDP per } \\
\text { capita }\end{array}$ & $\begin{array}{l}\text { Constraint } \\
\text { on Executive }\end{array}$ & $\begin{array}{c}\text { Protection for } \\
\text { Capital }\end{array}$ \\
\hline Hungary & 1850 & 20.73 & 871 & 1 & 1 \\
\hline India & 1000 & 0.80 & . & . & . \\
\hline India & 1100 & & . & . & . \\
\hline India & 1200 & 0.80 & . & . & . \\
\hline India & 1300 & 0.80 & . & . & . \\
\hline India & 1400 & 1.20 & . & . & . \\
\hline India & 1500 & 1.80 & 550 & . & . \\
\hline India & 1600 & 1.90 & 550 & . & . \\
\hline India & 1700 & 1.00 & 550 & . & . \\
\hline India & 1750 & 1.50 & . & . & . \\
\hline India & 1800 & 1.60 & 533 & . & . \\
\hline India & 1850 & 2.10 & 533 & . & . \\
\hline Ireland & 1000 & 6.33 & . & 1 & 1 \\
\hline Ireland & 1100 & & . & 1 & 1 \\
\hline Ireland & 1200 & 4.00 & . & 1 & 1 \\
\hline Ireland & 1300 & 7.63 & . & 3 & 2 \\
\hline Ireland & 1400 & 2.50 & . & 3 & 2 \\
\hline Ireland & 1500 & 2.38 & 526 & 2 & 2 \\
\hline Ireland & 1600 & 1.36 & 615 & 2 & 2 \\
\hline Ireland & 1700 & 5.00 & 715 & 4 & 4 \\
\hline Ireland & 1750 & 8.50 & . & 5 & 5 \\
\hline Ireland & 1800 & 9.83 & 839 & 6 & 6 \\
\hline Ireland & 1850 & 10.77 & 1775 & 6 & 6 \\
\hline Italy & 1000 & 12.26 & . & 1 & 1 \\
\hline Italy & 1100 & & . & 3 & 3 \\
\hline Italy & 1200 & 10.06 & . & 3 & 3 \\
\hline Italy & 1300 & 16.15 & . & 3 & 3 \\
\hline Italy & 1400 & 16.73 & . & 3 & 3 \\
\hline Italy & 1500 & 15.82 & 1100 & 3 & 3 \\
\hline Italy & 1600 & 23.77 & 1100 & 2 & 2 \\
\hline Italy & 1700 & 21.53 & 1100 & 1 & 1 \\
\hline Italy & 1750 & 21.03 & . & 1 & 1 \\
\hline Italy & 1800 & 25.63 & 1117 & 1 & 1 \\
\hline Italy & 1850 & 23.44 & 1499 & 1 & 1 \\
\hline Japan & 1000 & 3.90 & . & . & . \\
\hline Japan & 1100 & & . & . & . \\
\hline Japan & 1200 & 3.70 & . & . & . \\
\hline Japan & 1300 & 2.50 & . & . & . \\
\hline Japan & 1400 & 1.50 & . & . & . \\
\hline Japan & 1500 & 0.20 & 500 & . & . \\
\hline Japan & 1600 & 4.80 & 520 & . & . \\
\hline Japan & 1700 & 6.30 & 570 & . & . \\
\hline Japan & 1750 & 6.20 & . & . & . \\
\hline Japan & 1800 & 6.60 & 669 & . & . \\
\hline Japan & 1850 & 6.10 & 737 & . & . \\
\hline Netherlands & 1000 & 0.00 & . & 2 & 1 \\
\hline Netherlands & 1100 & & . & 2 & 1 \\
\hline Netherlands & 1200 & 2.00 & . & 2 & 2 \\
\hline
\end{tabular}




\begin{tabular}{|c|c|c|c|c|c|}
\hline Country & Date & Urbanization & $\begin{array}{l}\text { GDP per } \\
\text { capita }\end{array}$ & $\begin{array}{l}\text { Constraint } \\
\text { on Executive }\end{array}$ & $\begin{array}{c}\text { Protection for } \\
\text { Capital }\end{array}$ \\
\hline Netherlands & 1300 & 12.00 & . & 3 & 3 \\
\hline Netherlands & 1400 & 17.83 & . & 3 & 3 \\
\hline Netherlands & 1500 & 28.89 & 754 & 3 & 3 \\
\hline Netherlands & 1600 & 28.60 & 1368 & 5 & 5 \\
\hline Netherlands & 1700 & 38.10 & 2110 & 5 & 5 \\
\hline Netherlands & 1750 & 31.65 & . & 5 & 5 \\
\hline Netherlands & 1800 & 39.55 & 1821 & 4 & 4 \\
\hline Netherlands & 1850 & 35.23 & 2753 & 6 & 6 \\
\hline Norway & 1000 & 0.00 & . & 1 & 1 \\
\hline Norway & 1100 & & . & 1 & 1 \\
\hline Norway & 1200 & 0.00 & . & 1 & 1 \\
\hline Norway & 1300 & 3.00 & . & 1 & 1 \\
\hline Norway & 1400 & 0.00 & . & 1 & 1 \\
\hline Norway & 1500 & 2.00 & 640 & 1 & 1 \\
\hline Norway & 1600 & 2.80 & 760 & 1 & 1 \\
\hline Norway & 1700 & 4.50 & 900 & 1 & 1 \\
\hline Norway & 1750 & 6.67 & . & 1 & 1 \\
\hline Norway & 1800 & 7.00 & 1104 & 3 & 1 \\
\hline Norway & 1850 & 7.67 & 1432 & 1 & 1 \\
\hline Poland & 1000 & 0.00 & . & 1 & 1 \\
\hline Poland & 1100 & & . & 2 & 1 \\
\hline Poland & 1200 & 1.02 & . & 2 & 1 \\
\hline Poland & 1300 & 0.94 & . & 3 & 1 \\
\hline Poland & 1400 & 2.84 & . & 3 & 1 \\
\hline Poland & 1500 & 4.43 & 462 & 3 & 1 \\
\hline Poland & 1600 & 7.72 & 516 & 3 & 1 \\
\hline Poland & 1700 & 3.30 & 566 & 3 & 1 \\
\hline Poland & 1750 & 4.36 & . & 3 & 1 \\
\hline Poland & 1800 & 5.51 & 636 & 1 & 1 \\
\hline Poland & 1850 & 6.88 & 871 & 1 & 1 \\
\hline Portugal & 1000 & 2.50 & . & 1 & 1 \\
\hline Portugal & 1100 & & . & 1 & 1 \\
\hline Portugal & 1200 & 5.00 & . & 1 & 1 \\
\hline Portugal & 1300 & 6.88 & . & 1 & 1 \\
\hline Portugal & 1400 & 8.11 & . & 2 & 1 \\
\hline Portugal & 1500 & 16.64 & 632 & 1 & 1 \\
\hline Portugal & 1600 & 9.25 & 773 & 2 & 2 \\
\hline Portugal & 1700 & 12.10 & 854 & 2 & 2 \\
\hline Portugal & 1750 & 19.64 & . & 2 & 2 \\
\hline Portugal & 1800 & 18.69 & 963 & 2 & 2 \\
\hline Portugal & 1850 & 15.89 & 997 & 3 & 3 \\
\hline Romania & 1000 & 2.00 & . & 1 & 1 \\
\hline Romania & 1100 & . & . & 1 & 1 \\
\hline Romania & 1200 & 2.00 & . & 1 & 1 \\
\hline Romania & 1300 & 3.67 & . & 1 & 1 \\
\hline Romania & 1400 & 2.80 & . & 1 & 1 \\
\hline Romania & 1500 & 4.65 & 462 & 1 & 1 \\
\hline Romania & 1600 & 4.85 & 516 & 1 & 1 \\
\hline
\end{tabular}




\begin{tabular}{|c|c|c|c|c|c|}
\hline Country & Date & Urbanization & $\begin{array}{l}\text { GDP per } \\
\text { capita }\end{array}$ & $\begin{array}{l}\text { Constraint } \\
\text { on Executive }\end{array}$ & $\begin{array}{c}\text { Protection for } \\
\text { Capital }\end{array}$ \\
\hline Romania & 1700 & 5.72 & 566 & 1 & 1 \\
\hline Romania & 1750 & 5.54 & . & 1 & 1 \\
\hline Romania & 1800 & 5.05 & 636 & 1 & 1 \\
\hline Romania & 1850 & 6.51 & 871 & 1 & 1 \\
\hline Russia & 1000 & 3.80 & . & 1 & 1 \\
\hline Russia & 1100 & & . & 1 & 1 \\
\hline Russia & 1200 & 1.82 & . & 1 & 1 \\
\hline Russia & 1300 & 4.23 & . & 1 & 1 \\
\hline Russia & 1400 & 3.97 & . & 1 & 1 \\
\hline Russia & 1500 & 2.91 & 500 & 1 & 1 \\
\hline Russia & 1600 & 2.62 & 553 & 1 & 1 \\
\hline Russia & 1700 & 2.46 & 611 & 1 & 1 \\
\hline Russia & 1750 & 4.08 & . & 1 & 1 \\
\hline Russia & 1800 & 6.29 & 689 & 1 & 1 \\
\hline Russia & 1850 & 7.05 & 943 & 1 & 1 \\
\hline Serbia & 1000 & 3.14 & . & 1 & 1 \\
\hline Serbia & 1100 & & . & 1 & 1 \\
\hline Serbia & 1200 & 0.00 & . & 1 & 1 \\
\hline Serbia & 1300 & 2.58 & . & 1 & 1 \\
\hline Serbia & 1400 & 3.53 & . & 1 & 1 \\
\hline Serbia & 1500 & 4.98 & 462 & 1 & 1 \\
\hline Serbia & 1600 & 7.49 & 516 & 1 & 1 \\
\hline Serbia & 1700 & 6.00 & 566 & 1 & 1 \\
\hline Serbia & 1750 & 3.87 & . & 1 & 1 \\
\hline Serbia & 1800 & 7.77 & 636 & 1 & 1 \\
\hline Serbia & 1850 & 6.08 & 871 & 1 & 1 \\
\hline Spain & 1000 & 24.25 & . & 1 & 1 \\
\hline Spain & 1100 & & . & 1 & 1 \\
\hline Spain & 1200 & 6.96 & . & 2 & 1 \\
\hline Spain & 1300 & 11.79 & . & 2 & 1 \\
\hline Spain & 1400 & 9.98 & . & 2 & 2 \\
\hline Spain & 1500 & 14.15 & 698 & 1 & 1 \\
\hline Spain & 1600 & 20.95 & 900 & 1 & 1 \\
\hline Spain & 1700 & 16.86 & 900 & 1 & 1 \\
\hline Spain & 1750 & 17.08 & . & 1 & 1 \\
\hline Spain & 1800 & 24.07 & 1063 & 2 & 2 \\
\hline Spain & 1850 & 25.53 & 1376 & 4 & 4 \\
\hline Sweden & 1000 & 0.00 & . & 1 & 1 \\
\hline Sweden & 1100 & & . & 1 & 1 \\
\hline Sweden & 1200 & 0.45 & . & 1 & 1 \\
\hline Sweden & 1300 & 1.63 & . & 1 & 1 \\
\hline Sweden & 1400 & 3.29 & . & 1 & 1 \\
\hline Sweden & 1500 & 4.25 & 695 & 2 & 1 \\
\hline Sweden & 1600 & 4.10 & 824 & 2 & 1 \\
\hline Sweden & 1700 & 6.80 & 977 & 3 & 2 \\
\hline Sweden & 1750 & 6.90 & . & 3 & 2 \\
\hline Sweden & 1800 & 6.56 & 1198 & 3 & 3 \\
\hline Sweden & 1850 & 6.86 & 1664 & 3 & 3 \\
\hline
\end{tabular}




\begin{tabular}{|c|c|c|c|c|c|}
\hline Country & Date & Urbanization & $\begin{array}{l}\text { GDP per } \\
\text { capita }\end{array}$ & $\begin{array}{c}\text { Constraint } \\
\text { on Executive }\end{array}$ & $\begin{array}{c}\text { Protection for } \\
\text { Capital }\end{array}$ \\
\hline Switzerland & 1000 & 0.33 & . & 1 & 1 \\
\hline Switzerland & 1100 & & . & 1 & 1 \\
\hline Switzerland & 1200 & 2.40 & . & 1 & 1 \\
\hline Switzerland & 1300 & 2.38 & . & 2 & 2 \\
\hline Switzerland & 1400 & 8.50 & . & 2 & 2 \\
\hline Switzerland & 1500 & 6.63 & 742 & 2 & 2 \\
\hline Switzerland & 1600 & 5.20 & 880 & 3 & 3 \\
\hline Switzerland & 1700 & 6.48 & 1044 & 3 & 3 \\
\hline Switzerland & 1750 & 8.13 & . & 4 & 4 \\
\hline Switzerland & 1800 & 7.89 & 1280 & 5 & 5 \\
\hline Switzerland & 1850 & 12.96 & 2202 & 7 & 7 \\
\hline Turkey & 1000 & 6.20 & . & 1 & 1 \\
\hline Turkey & 1100 & • & . & 1 & 1 \\
\hline Turkey & 1200 & 4.50 & . & 1 & 1 \\
\hline Turkey & 1300 & 3.00 & . & 1 & 1 \\
\hline Turkey & 1400 & 4.80 & . & 1 & 1 \\
\hline Turkey & 1500 & 5.90 & 572 & 1 & 1 \\
\hline Turkey & 1600 & 12.00 & 575 & 1 & 1 \\
\hline Turkey & 1700 & 12.20 & 571 & 1 & 1 \\
\hline Turkey & 1750 & 10.40 & • & 1 & 1 \\
\hline Turkey & 1800 & 9.10 & 575 & 1 & 1 \\
\hline Turkey & 1850 & 10.10 & 543 & 1 & 1 \\
\hline
\end{tabular}

Czech republic represents Czechoslovakia. Serbia represents former Yugoslavia. 
Appendix Table 3

Atlantic Trade, Urbanization, and GDP: Alternative Trade Series

\begin{tabular}{|c|c|c|c|c|c|c|c|c|c|c|c|}
\hline & \multicolumn{11}{|c|}{ Panel A: Dependent variable is urbanization, structured specification } \\
\hline & $\begin{array}{l}\text { Panel, } 1300-1850 \\
(1)\end{array}$ & $\begin{array}{l}\text { Panel, } 1000-1850 \\
(2)\end{array}$ & $\begin{array}{c}\text { Panel, 1300- } \\
1850 \\
\text { (3) }\end{array}$ & $\begin{array}{c}\text { Panel, 1000- } \\
1850 \\
(4)\end{array}$ & $\begin{array}{l}\text { Panel, 1300- } \\
1850, \\
\text { unweighted } \\
(5)\end{array}$ & $\begin{array}{l}\text { Panel, 1300- } \\
\text { 1850, with Asia } \\
\text { (6) }\end{array}$ & $\begin{array}{l}\text { Panel, 1300- } \\
\text { 1850, without } \\
\text { Britain } \\
\text { (7) }\end{array}$ & $\begin{array}{c}\text { Panel, 1300- } \\
1850 \\
(8)\end{array}$ & $\begin{array}{c}\text { Panel, 1000- } \\
1850 \\
(9)\end{array}$ & $\begin{array}{c}\text { Panel, 1300- } \\
1850 \\
\text { unweighted } \\
(10)\end{array}$ & $\begin{array}{c}\text { Panel, 1300- } \\
1850 \\
(11)\end{array}$ \\
\hline & & & \multicolumn{9}{|c|}{ Atlantic Trade is measured by: } \\
\hline & & & \multicolumn{5}{|c|}{ Atlantic trader dummy } & \multicolumn{3}{|c|}{ Atlantic coastline-to- land area } & $\begin{array}{l}\text { Average pop. in } \\
\text { Atlantic ports }\end{array}$ \\
\hline $\begin{array}{l}\text { p-value for Western Europe } x \\
\text { year dummies, 1600-1850 }\end{array}$ & {$[0.00]$} & {$[0.00]$} & {$[0.43]$} & {$[0.08]$} & {$[0.83]$} & {$[0.00]$} & {$[0.10]$} & {$[0.17]$} & {$[0.03]$} & {$[0.81]$} & {$[0.17]$} \\
\hline $\begin{array}{l}\text { Atlantic Trade } \mathrm{x} \\
\text { Volume of Aggregate Atlantic Trade }\end{array}$ & & & $\begin{array}{c}0.011 \\
(0.0023)\end{array}$ & $\begin{array}{l}0.0085 \\
(0.0019)\end{array}$ & $\begin{array}{c}0.016 \\
(0.0033)\end{array}$ & $\begin{array}{l}0.011 \\
(0.0028)\end{array}$ & $\begin{array}{l}0.005 \\
(0.0017)\end{array}$ & $\begin{array}{l}0.74 \\
(0.07)\end{array}$ & $\begin{array}{l}0.64 \\
(0.06)\end{array}$ & $\begin{array}{l}0.62 \\
(0.11)\end{array}$ & $\begin{array}{l}0.36 \\
(0.04)\end{array}$ \\
\hline R-Squared & 0.87 & 0.85 & 0.89 & 0.87 & 0.81 & 0.84 & 0.92 & 0.93 & 0.91 & 0.82 & 0.92 \\
\hline \multirow[t]{6}{*}{ Number of Observations } & 192 & 240 & 192 & 240 & 192 & 208 & 184 & 192 & 240 & 192 & 192 \\
\hline & \multicolumn{11}{|c|}{ Panel B: Dependent variable is log GDP per capita, structured specification } \\
\hline & Panel, $1500-1820$ & Panel, 1500-1870 & $\begin{array}{l}\text { Panel, 1500- } \\
\quad 1820\end{array}$ & $\begin{array}{l}\text { Panel, 1500- } \\
1870\end{array}$ & $\begin{array}{l}\text { Panel, } 1500- \\
1820 \\
\text { unweighted }\end{array}$ & $\begin{array}{l}\text { Panel, } 1500- \\
1820 \text {, with Asia }\end{array}$ & $\begin{array}{l}\text { Panel, } 1500- \\
\text { 1820, without } \\
\text { Britain }\end{array}$ & $\begin{array}{l}\text { Panel, 1500- } \\
1820\end{array}$ & $\begin{array}{l}\text { Panel, 1500- } \\
1870\end{array}$ & $\begin{array}{l}\text { Panel, } 1500- \\
1820 \\
\text { unweighted }\end{array}$ & $\begin{array}{l}\text { Panel, 1500- } \\
1820\end{array}$ \\
\hline & (1) & $(2)$ & (3) & (4) & (5) & $(6)$ & $(7)$ & $(8)$ & $(9)$ & $(10)$ & (11) \\
\hline & & & \multicolumn{9}{|c|}{ Atlantic Trade is measured by: } \\
\hline & & & \multicolumn{5}{|c|}{ Atlantic trader dummy } & \multicolumn{3}{|c|}{ Atlantic coastline-to- land area } & $\begin{array}{l}\text { Average pop. in } \\
\text { Atlantic ports }\end{array}$ \\
\hline $\begin{array}{l}\text { p-value for Western Europe } x \\
\text { year dummies, 1600-1850 }\end{array}$ & {$[0.44]$} & {$[0.05]$} & {$[0.91]$} & {$[0.51]$} & {$[0.14]$} & {$[0.01]$} & {$[0.87]$} & {$[0.98]$} & {$[0.64]$} & {$[0.23]$} & {$[0.98]$} \\
\hline $\begin{array}{l}\text { Atlantic Trade x } \\
\text { Volume of Aggregate Atlantic Trade }\end{array}$ & & & $\begin{array}{l}0.072 \\
(0.017)\end{array}$ & $\begin{array}{l}0.032 \\
(0.015)\end{array}$ & $\begin{array}{l}0.049 \\
(0.019)\end{array}$ & $\begin{array}{l}0.072 \\
(0.030)\end{array}$ & $\begin{array}{l}0.053 \\
(0.016)\end{array}$ & $\begin{array}{l}3.38 \\
(0.56)\end{array}$ & $\begin{array}{l}2.82 \\
(0.45)\end{array}$ & $\begin{array}{l}2.34 \\
(0.61)\end{array}$ & $\begin{array}{l}0.00 \\
0.00\end{array}$ \\
\hline R-Squared & 0.94 & 0.94 & 0.96 & 0.95 & 0.96 & 0.92 & 0.96 & 0.96 & 0.96 & 0.96 & 0.96 \\
\hline Number of Observations & 96 & 120 & 96 & 120 & 96 & 104 & 92 & 96 & 120 & 96 & 96 \\
\hline
\end{tabular}

Standard errors are in parentheses. Panel regressions with full set of country and year dummies; regressions are weighted unless otherwise stated. Weighted regressions use total population in each year as weights, from McEvedy and Jones. In Panel A, dependent variable is level of urbanization (percent of population living in towns with more than 5,000 population.) Urbanization in Europe is from Bairoch, Batou and Chèvre, and urbanization in Asia is from Chandler. In Panel B, dependent variable is $\log$ GDP per capita, from Maddison. We report results with three different measures of Atlantic trade: a dummy for whether a country was an Atlantic trader (one for Britain, the Netherlands, France, Spain and Portugal; zero for all others) in columns 3, 4, 5, 6 and 7; the ratio of Atlantic coastline to land area, defining the Atlantic broadly to include Belgium, Denmark, Germany, Ireland and Norway (columns 8, 9, and 10); the average percentage population in Atlantic ports during 1300-1850 is multiplied by 100 (column 11). Column 6 includes the available data on Asia (just for India and China) and column 7 drops Britain.

Total Atlantic Trade is the log average number of voyages per year, calculated from Williamson and O'Rourke, as described in the Appendix. For more detailed data definitions and sources see Appendix Table 1. 
Appendix Table 4

Atlantic Trade, Urbanization, and GDP: Country-Specific Measures of Atlantic Trade

\begin{tabular}{|c|c|c|c|c|c|c|c|}
\hline & $(1)$ & $(2)$ & $(3)$ & $(4)$ & $(5)$ & $(6)$ & $(7)$ \\
\hline & \multicolumn{7}{|c|}{ Panel A: Dependent Variable is Urbanization } \\
\hline & Panel, 1300-1850 & $\begin{array}{l}\text { Panel, 1000- } \\
\quad 1850\end{array}$ & $\begin{array}{l}\text { Panel, 1300- } \\
\quad 1850\end{array}$ & $\begin{array}{l}\text { Panel, 1000- } \\
\quad 1850\end{array}$ & $\begin{array}{c}\text { Panel, } 1300- \\
1850 \\
\text { unweighted }\end{array}$ & $\begin{array}{l}\text { Panel, 1300- } \\
\text { 1850, with Asia }\end{array}$ & $\begin{array}{l}\text { Panel, 1300- } \\
\text { 1850, without } \\
\text { Britain }\end{array}$ \\
\hline $\begin{array}{l}\text { p-value for Western Europe } x \\
\text { year dummies, } 1600-1850\end{array}$ & {$[0.00]$} & {$[0.00]$} & {$[0.43]$} & {$[0.13]$} & {$[0.86]$} & {$[0.00]$} & {$[0.05]$} \\
\hline $\begin{array}{l}\text { Country-Specific Measure of Atlantic Trade x } \\
\text { Volume of Aggregate Atlantic Trade }\end{array}$ & & & $\begin{array}{l}0.0140 \\
(0.0022)\end{array}$ & $\begin{array}{l}0.0130 \\
(0.0020)\end{array}$ & $\begin{array}{l}0.0202 \\
(0.0035)\end{array}$ & $\begin{array}{l}0.0142 \\
(0.0027)\end{array}$ & $\begin{array}{l}0.0056 \\
(0.0019)\end{array}$ \\
\hline R-Squared & 0.87 & 0.85 & 0.9 & 0.88 & 0.82 & 0.85 & 0.92 \\
\hline \multirow[t]{3}{*}{ Number of Observations } & 192 & 240 & 192 & 240 & 192 & 208 & 184 \\
\hline & \multicolumn{7}{|c|}{ Panel B: Dependent Variable is Log GDP per capita } \\
\hline & Panel, $1500-1820$ & $\begin{array}{c}\text { Panel, } 1500- \\
1870\end{array}$ & $\begin{array}{c}\text { Panel, } 1500- \\
1820\end{array}$ & $\begin{array}{c}\text { Panel, } 1500- \\
1820\end{array}$ & $\begin{array}{c}\text { Panel, } 1500- \\
1820, \\
\text { unweighted }\end{array}$ & $\begin{array}{l}\text { Panel, } 1500- \\
1820 \text {, with Asia }\end{array}$ & $\begin{array}{l}\text { Panel, } 1500- \\
\text { 1820, without } \\
\text { Britain }\end{array}$ \\
\hline $\begin{array}{l}\text { p-value for Western Europe } x \\
\text { year dummies, } 1600-1850\end{array}$ & {$[0.44]$} & {$[0.05]$} & {$[0.94]$} & {$[0.45]$} & {$[0.07]$} & {$[0.00]$} & {$[0.94]$} \\
\hline Country-Specific Measure of Atlantic Trade x & & & 0.055 & 0.057 & 0.061 & 0.055 & 0.041 \\
\hline Volume of Aggregate Atlantic Trade & & & $(0.009)$ & $(0.010)$ & $(0.011)$ & $(0.017)$ & $(0.010)$ \\
\hline R-Squared & 0.94 & 0.94 & 0.96 & 0.96 & 0.97 & 0.93 & 0.96 \\
\hline \multirow[t]{3}{*}{ Number of Observations } & 96 & 120 & 96 & 120 & 96 & 104 & 92 \\
\hline & \multicolumn{7}{|c|}{ Panel C: Dependent Variable is Constraint on the Executive } \\
\hline & Panel, $1300-1850$ & $\begin{array}{c}\text { Panel, 1300- } \\
1850\end{array}$ & $\begin{array}{c}\text { Panel, 1300- } \\
1850\end{array}$ & $\begin{array}{l}\text { Panel, 1000- } \\
1850\end{array}$ & $\begin{array}{l}\text { 1850, with } \\
\text { Asia }\end{array}$ & $\begin{array}{c}\text { Panel, 1000- } \\
1850\end{array}$ & $\begin{array}{c}\text { Panel, 1000- } \\
1850\end{array}$ \\
\hline $\begin{array}{l}\text { p-value for Western Europe } x \\
\text { year dummies, } 1600-1850\end{array}$ & {$[0.00]$} & {$[0.00]$} & {$[0.00]$} & {$[0.00]$} & {$[0.00]$} & {$[0.00]$} & {$[0.00]$} \\
\hline Country-Specific Measure of Atlantic Trade x & & & 0.480 & 0.470 & 0.324 & 0.481 & 0.430 \\
\hline Volume of Aggregate Atlantic Trade & & & $(0.054)$ & $(0.048)$ & $(0.061)$ & $(0.054)$ & $(0.061)$ \\
\hline R-Squared & 0.75 & 0.71 & 0.83 & 0.77 & 0.77 & 0.8 & 0.76 \\
\hline Number of Observations & 192 & 240 & 192 & 240 & 216 & 192 & 184 \\
\hline
\end{tabular}

Standard errors are in parentheses. Panel regressions with full set of country and year dummies, weighted by current population (apart from column 5). Dependent variable is urbanization in Panel A, log GDP per capita in Panel B, and constraint on the executive in Panel C. Western Europe dummies interacted with years (from 1600) are included in all columns, but only the joint test for significance is reported to save space. Urbanization in Europe is from Bairoch, Batou and Chèvre, and urbanization in Asia is from Bairoch. Log GDP per capita is from Maddison. Constraint on the executive is coded from Langer. The measure of Atlantic trade for each country is $\max \{0, \log$ of country's Atlantic trade for that year $\}$. Atlantic Trade is the log average number of voyages per year; in this table this is different for each country. For data definitions and sources see Appendix Table 1. 
Appendix Table 5

Atlantic Trade and Institutions: Alternative Measures of Institutions

\begin{tabular}{|c|c|c|c|c|c|c|c|c|c|}
\hline & $\begin{array}{c}\text { Panel, 1300- } \\
1850 \\
(1)\end{array}$ & $\begin{array}{l}\text { Panel, } 1300-1850 \\
\text { (2) }\end{array}$ & $\begin{array}{l}\text { Panel, } 1300- \\
\quad 1850 \\
(3)\end{array}$ & $\begin{array}{l}\text { Panel, } 1300- \\
1850, \\
\text { controlling for } \\
\text { religion } \\
(4)\end{array}$ & $\begin{array}{c}\text { Panel, } 1300 \text { to } \\
1850, \\
\text { controlling for } \\
\text { wars } \\
(5)\end{array}$ & $\begin{array}{l}\text { Panel, } 1300 \text { to } \\
1850 \text {, controlling } \\
\text { for Roman } \\
\text { heritage } \\
\text { (6) }\end{array}$ & $\begin{array}{l}\text { Panel, } 1300 \text { to } \\
\text { 1850, controlling } \\
\text { for latitude } \\
\text { (7) }\end{array}$ & $\begin{array}{l}\text { Panel, } 1300 \text { to } \\
\text { 1850, using Atlantic } \\
\text { coast-area measure } \\
\text { of Atlantic trade } \\
\text { (8) }\end{array}$ & $\begin{array}{l}\text { Panel, } 1300 \text { to } \\
1850 \text {, using } \\
\text { Atlantic coast-area } \\
\text { measure of Atlantic } \\
\text { trade } \\
\text { (9) }\end{array}$ \\
\hline $\begin{array}{l}\text { p-value for Western Europe } x \\
\text { year dummies, } 1600-1850\end{array}$ & {$[0.00]$} & {$[0.52]$} & $\begin{array}{l}\text { Pane } \\
{[0.00]}\end{array}$ & $\begin{array}{l}\text { A: Depende } \\
\quad[0.00]\end{array}$ & $\begin{array}{l}\text { ent Variable } i \\
\qquad[0.00]\end{array}$ & $\begin{array}{l}\text { is Constraint or } \\
{[0.00]}\end{array}$ & $\begin{array}{r}\text { Executive } \\
\quad[0.00]\end{array}$ & {$[0.00]$} & {$[0.00]$} \\
\hline Atlantic Trade x 1500 & & $\begin{array}{l}-0.20 \\
(0.45)\end{array}$ & & & & & & $\begin{array}{l}-19.61 \\
(22.97)\end{array}$ & \\
\hline Atlantic Trade x 1600 & & $\begin{array}{c}0.12 \\
(0.50)\end{array}$ & & & & & & $\begin{array}{l}11.79 \\
(22.97)\end{array}$ & \\
\hline Atlantic Trade x 1700 & & $\begin{array}{l}0.30 \\
(0.46)\end{array}$ & & & & & & $\begin{array}{l}11.79 \\
(22.95)\end{array}$ & \\
\hline Atlantic Trade x 1750 & & $\begin{array}{l}0.40 \\
(0.45)\end{array}$ & & & & & & $\begin{array}{l}79.53 \\
(20.82)\end{array}$ & \\
\hline Atlantic Trade x 1800 & & $\begin{array}{l}2.25 \\
(0.42)\end{array}$ & & & & & & $\begin{array}{l}74.88 \\
(18.99)\end{array}$ & \\
\hline Atlantic Trade x 1850 & & $\begin{array}{l}3.13 \\
(0.39)\end{array}$ & & & & & & $\begin{array}{l}68.54 \\
(17.16)\end{array}$ & \\
\hline $\begin{array}{l}\text { Atlantic Trade } \mathrm{x} \\
\text { Volume of Aggregate Atlantic Trade }\end{array}$ & & & $\begin{array}{l}0.44 \\
(0.06)\end{array}$ & $\begin{array}{l}0.48 \\
(0.06)\end{array}$ & $\begin{array}{l}0.44 \\
(0.06)\end{array}$ & $\begin{array}{l}0.55 \\
(0.07)\end{array}$ & $\begin{array}{l}0.45 \\
(0.06)\end{array}$ & & $\begin{array}{l}12.25 \\
(2.31)\end{array}$ \\
\hline $\mathrm{p}$-value for Protestant $\mathrm{x}$ year effect & & & & {$[0.00]$} & & & & & \\
\hline Wars per year in preceding century & & & & & $\begin{array}{c}0.04 \\
(0.20)\end{array}$ & & & & \\
\hline p-value for Roman Heritage x Year & & & & & & {$[0.00]$} & & & \\
\hline p-value for Latitude x Year & & & & & & & {$[0.009]$} & & \\
\hline R-Squared & 0.73 & 0.85 & 0.80 & 0.84 & 0.80 & 0.85 & 0.83 & 0.79 & 0.77 \\
\hline Number of Observations & 192 & 192 & 192 & 192 & 176 & 192 & 192 & 192 & 192 \\
\hline
\end{tabular}

Standard errors are in parentheses. Weighted panel regressions with full set of country and year dummies. Weights are total population in each country in each year, from McEvedy and Jones. Dependent variable is constraint on executive in columns, coded from Langer, as explained in the Appendix; in this alternative coding of institutions, Ireland has a score of 1 in all years and Spain has a score of 2 in 1500 and 1600 . All columns use the Atlantic trader dummy (one for Britain, France, Spain, Portugal and the Netherlands; zero for all others) as the measure of Atlantic trade, apart from columns 8 and 9 which use the ratio of Atlantic coastline (broadly defined to include Belgium, Denmark, Germany, Ireland and Norway) to land area. Total Atlantic Trade is the log average number of voyages per year. Protestant is a dummy for whether country was majority Protestant in 1600. Protestant $\mathrm{x}$ Year is the Protestant dummy interacted with year dummies for 1600 and after. Wars per year are for the preceding century through 1700, 1700-1750 for 1750, 1750-1800 for 1800 and 1800-1850 for 1850 . Roman heritage is dummy for whether country was in Roman empire and not subsequently in Ottoman empire; this is interacted with year dummies for 1600 and after.

Latitude is distance from the equator for capital city of this country today; this is interacted with year for 1600 and after. For more detailed data definitions and sources see Appendix Table 1. 


\title{
Figure 1A
}

\author{
Urbanization rates \\ weighted by population
}

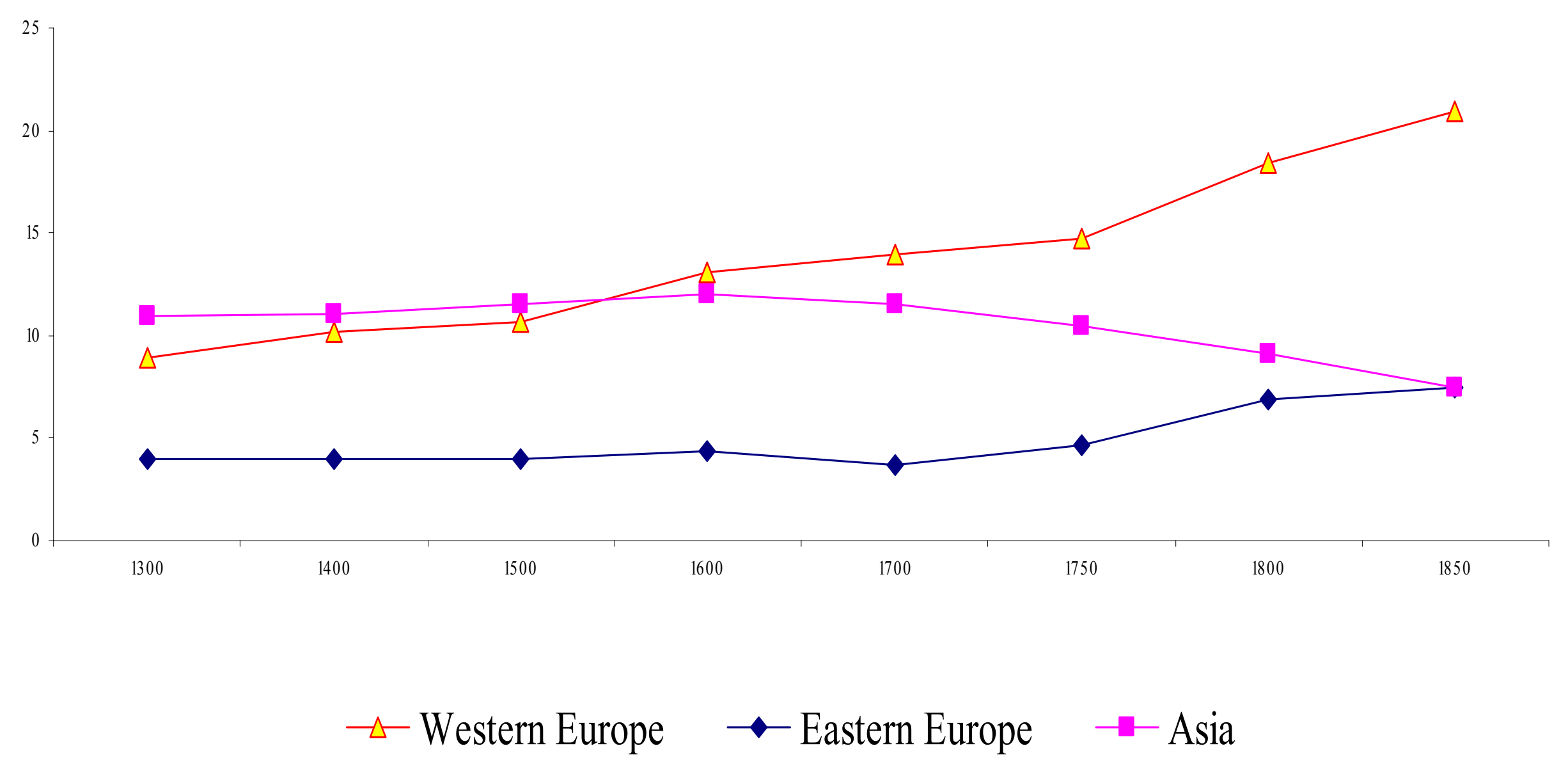




\title{
Figure 1B
}

\author{
Urbanization rates \\ weighted by population
}

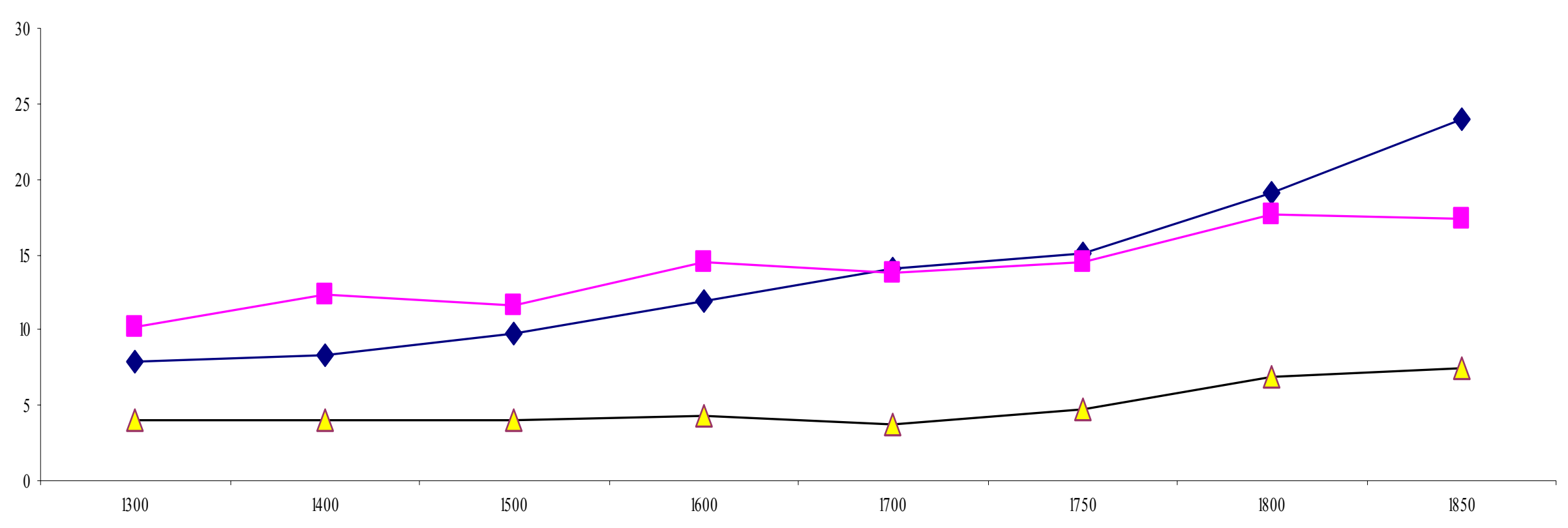

$\multimap$ Atlantic traders

- Western Europe not Atlantic traders

$\rightarrow-$ Eastern Europe 


\section{Figure 2A}

\section{GDP per capita from 1500}

weighted by population

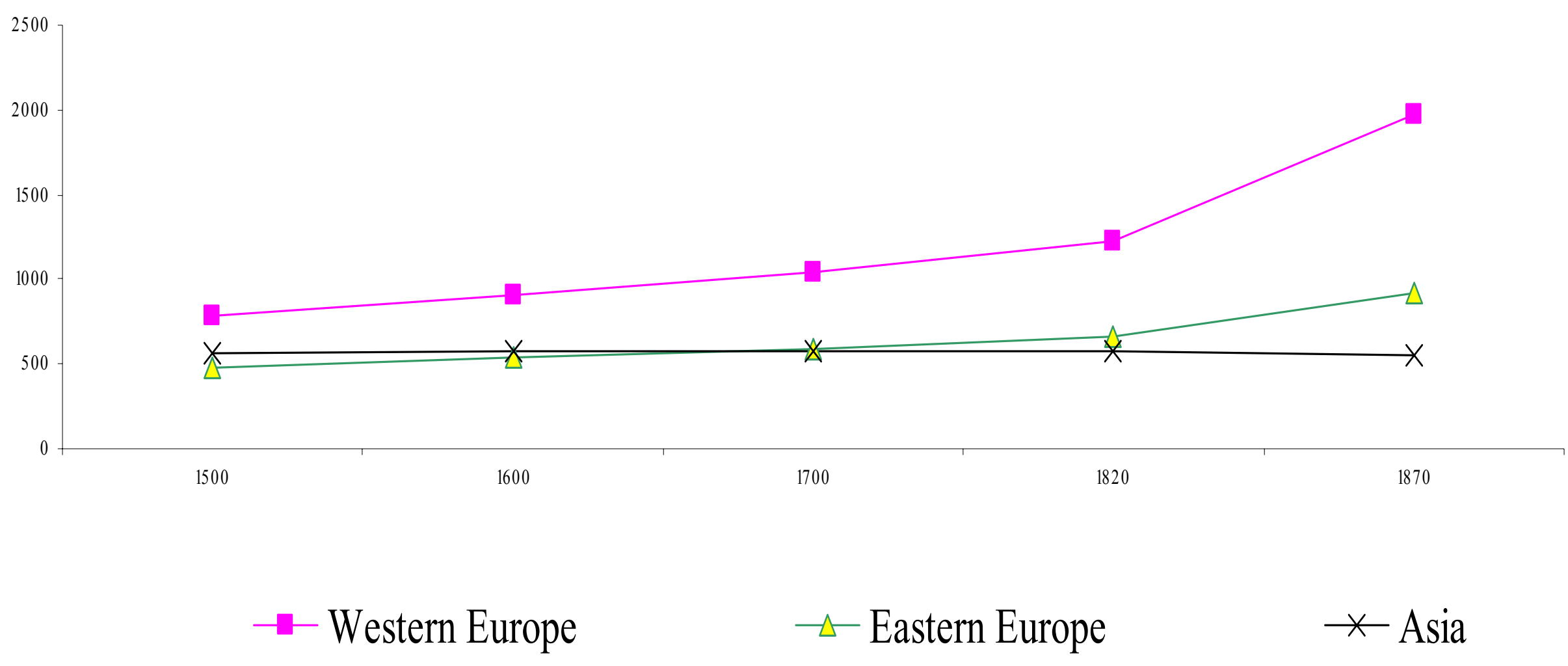




\section{Figure 2B}

GDP per capita from 1500

weighted by population

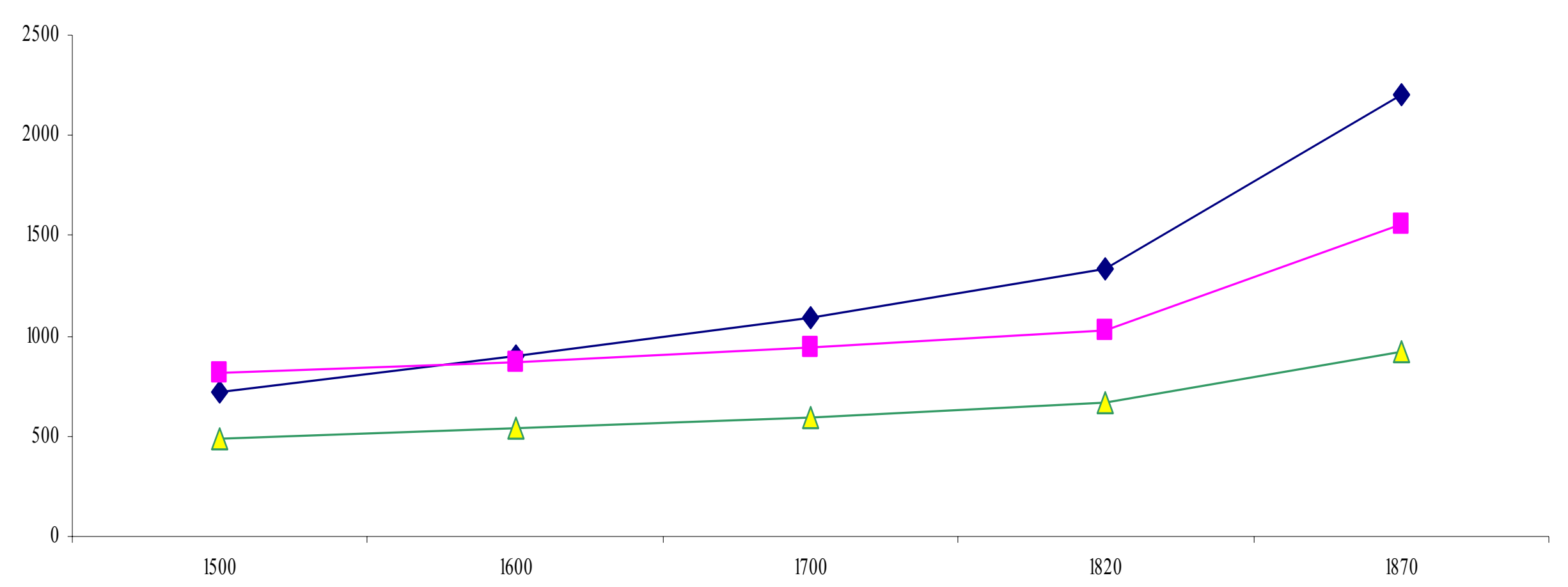

$\rightarrow$ Atlantic traders $\rightarrow-$ Western Europe not Atlantic traders $\quad-$ Eastern Europe 


\section{Figure 3}

Voyages per year: Atlantic Trade (to Americas, African coast and Asia via Cape), and Mediterranean (W.Europe to Levant)

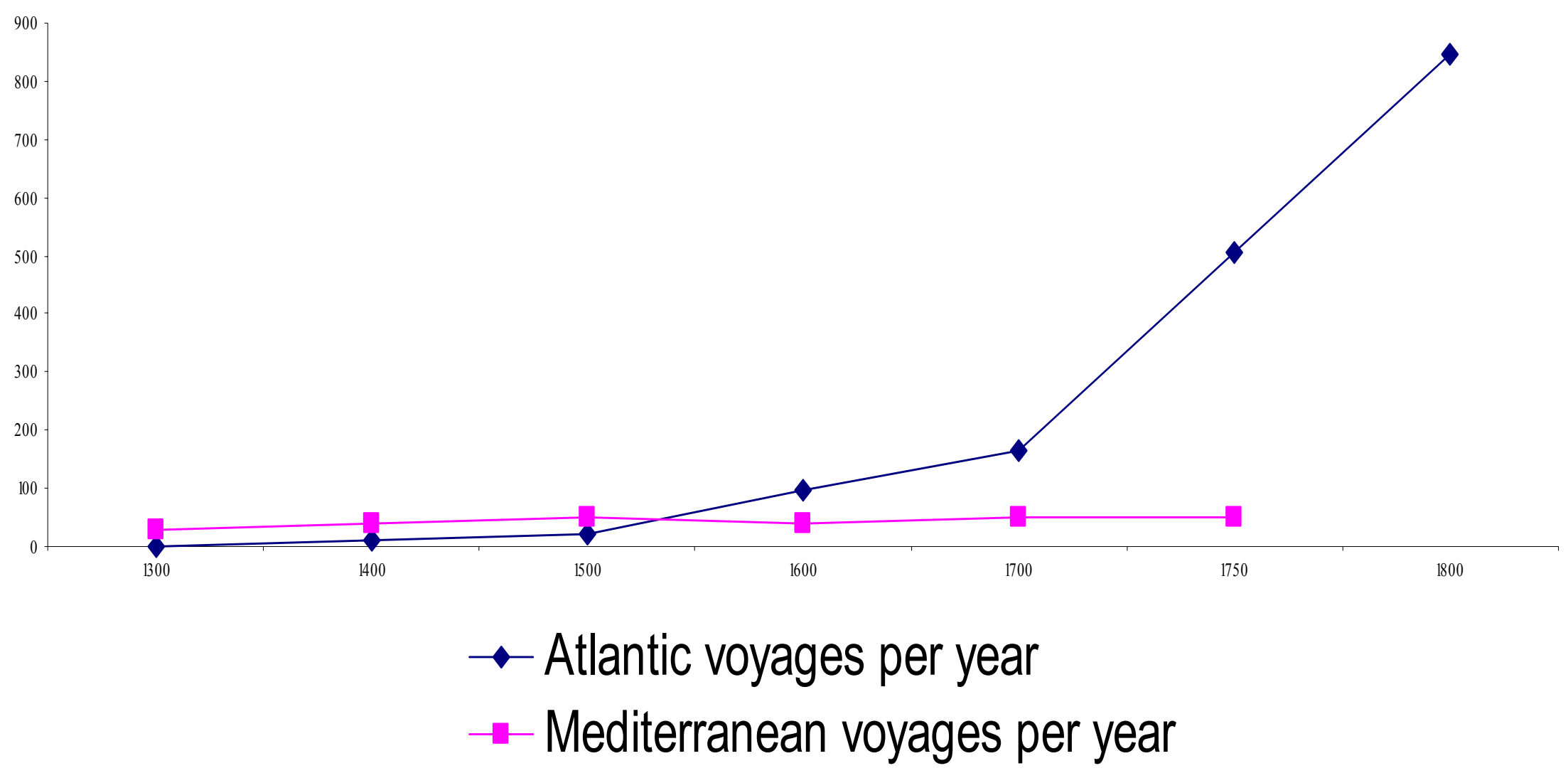




\section{Figure 4}

Average of log city population in Atlantic ports, West European cities that are not Atlantic ports, and Eastern Europe (balanced panel)

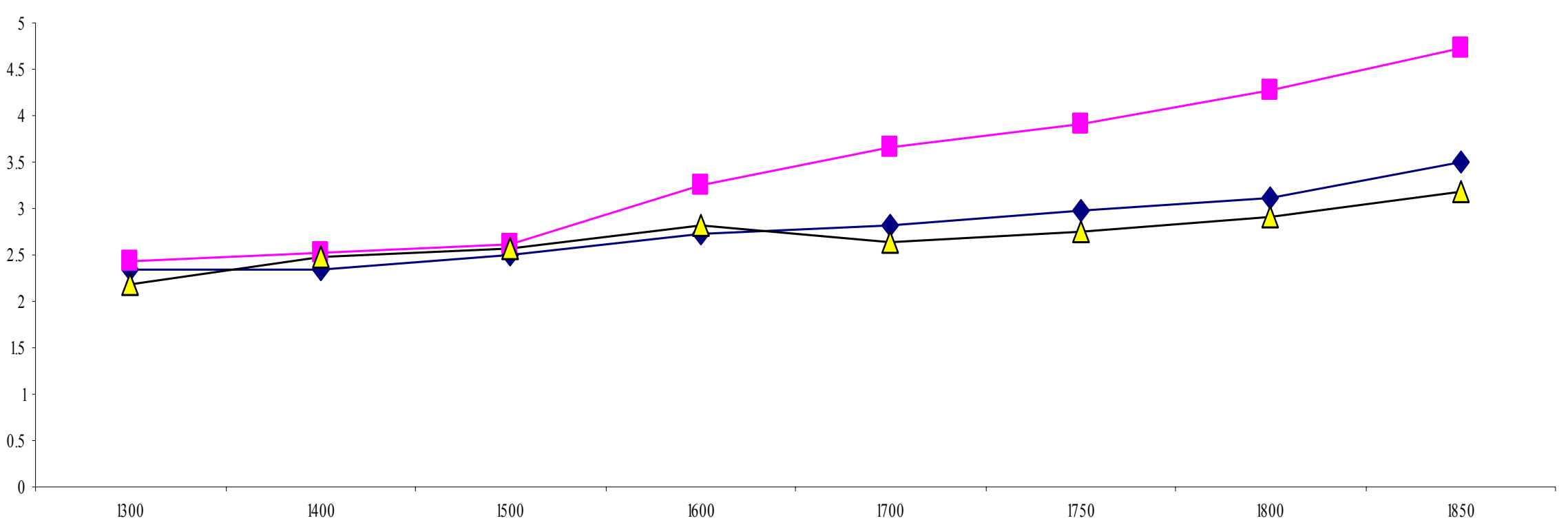




\section{Figure 5}

Average of log population in Atlantic ports, Mediterranean ports, and West European cities that are not ports (balanced panel)

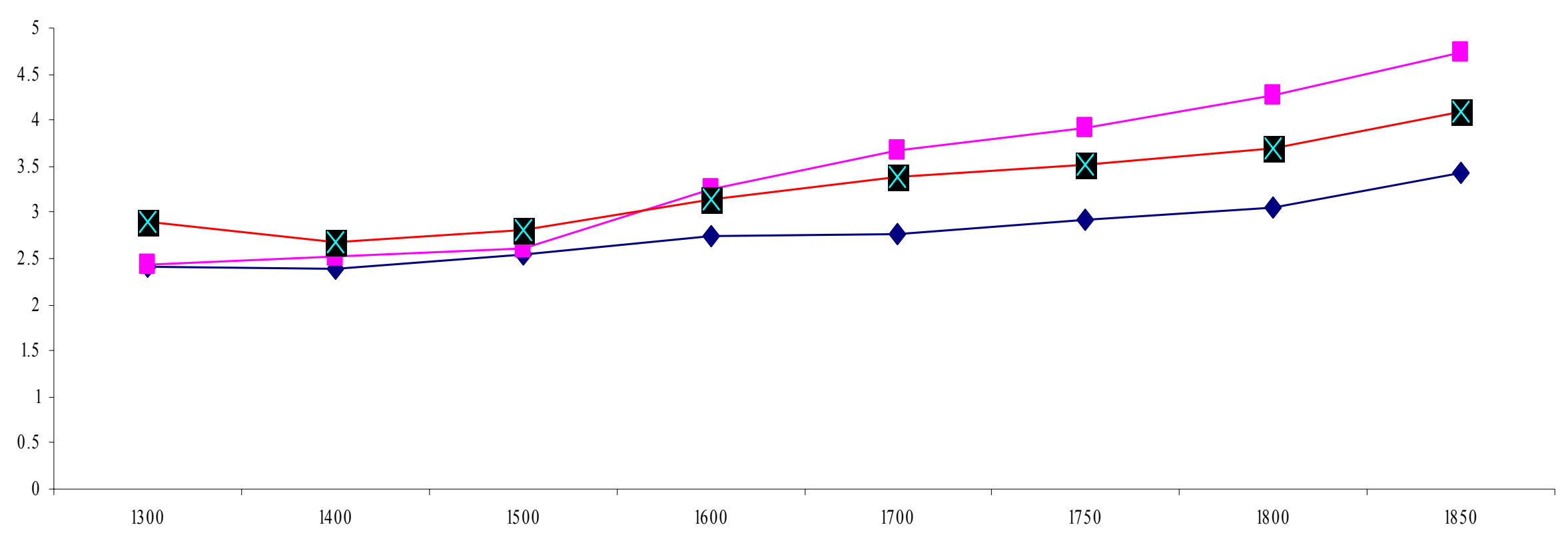

$\rightarrow-$ Inland West European cities - - Atlantic ports $-₫$-Mediterranean ports 


\section{Figure 6}

Average of log population in Iberian Atlantic ports and other cities

(balanced panel)

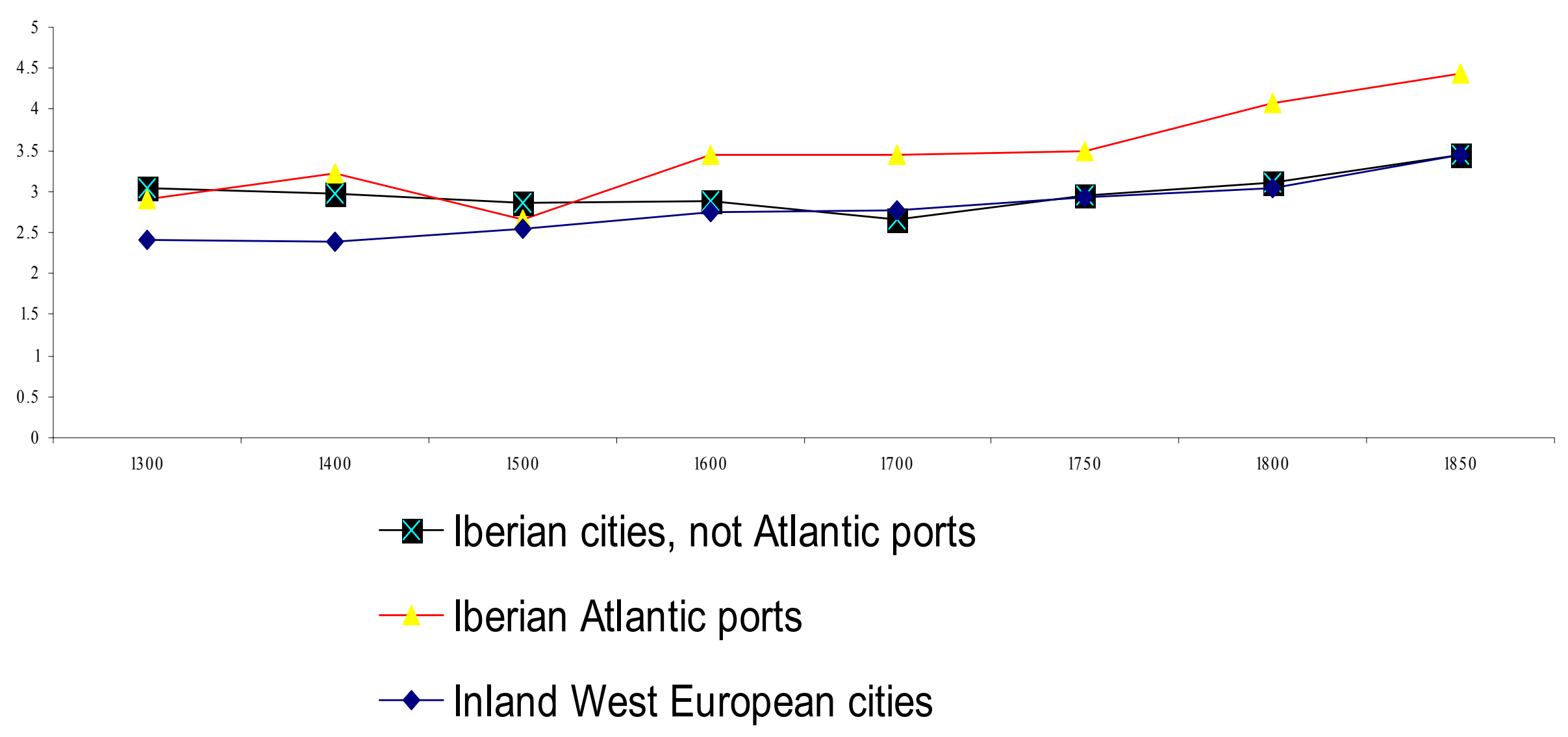




\section{Figure 7}

Average of log population in British and Dutch Atlantic ports and other cities

(balanced panel)

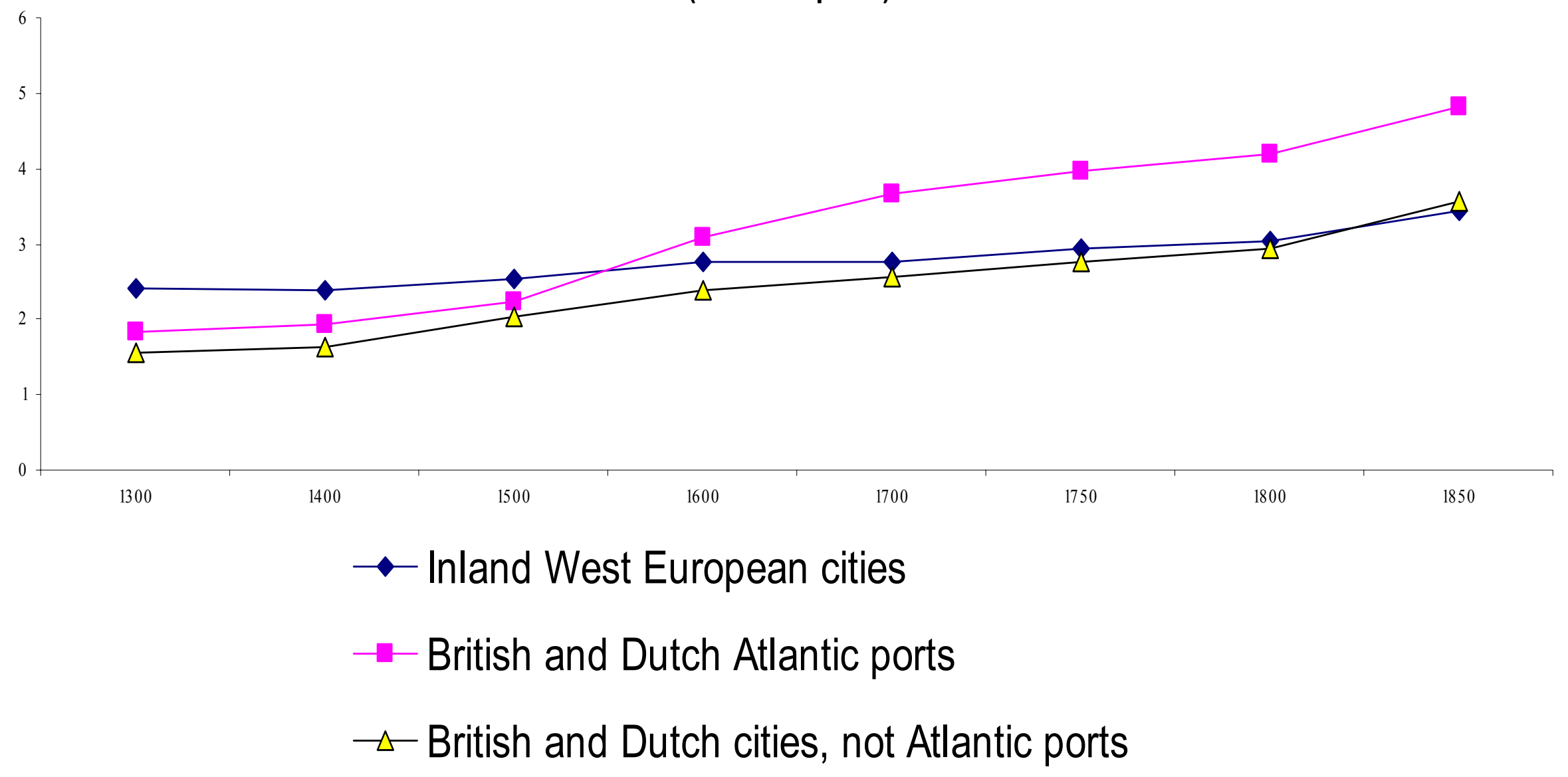




\section{Figure 8}

Constraint on the Executive from 1300 to 1850

weighted by population

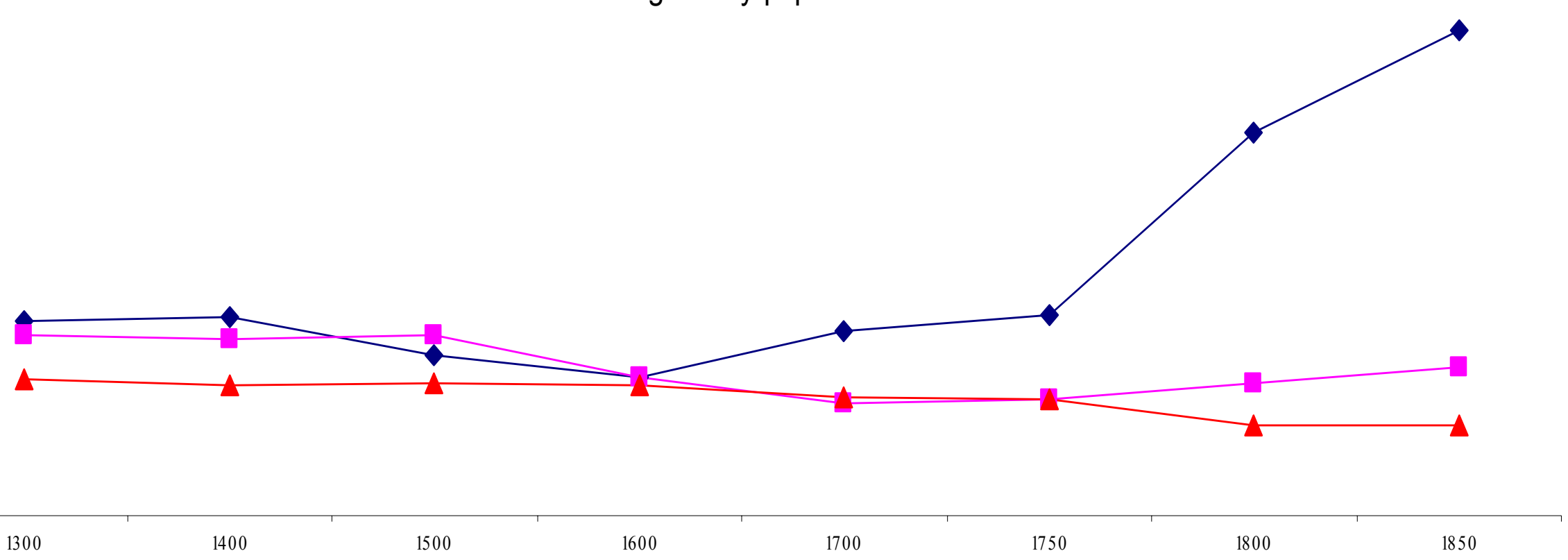

$\rightarrow$ Atlantic traders $\rightarrow-$ Western Europe not Atlantic traders $\rightarrow-$ Eastern Europe 